\title{
ANÁLISE DO TEMPO DE TRAMITAÇÃO DE PROCESSOS DE LICENCIAMENTO AMBIENTAL: ESTUDO DE CASOS DE TERMELÉTRICAS NO ESTADO DE SÃO PAULO.
}

Dissertação apresentada à Escola de Engenharia de São Carlos, da Universidade de São Paulo, como parte dos requisitos para a obtenção do título de Mestre em Ciências da Engenharia Ambiental.

Orientador: Prof. Dr. Victor Eduardo Lima Ranieri

São Carlos

2008 
FOLHA DE APROVAÇÃO 
VERSO 
Dedico este trabalho especialmente à minha família, com muito carinho. 


\section{AGRADECIMENTOS}

Agradeço ao Prof. Dr. Victor Eduardo Lima Ranieri pela orientação e confiança em mim depositada na realização deste trabalho.

Aos professores Horta Nogueira e Nemésio Salvador que dispuseram seu tempo e atenção, prestando enorme colaboração através de sugestões e críticas que edificaram este trabalho.

Aos professores Marcelo Pereira de Souza, Evaldo Luis Gaeta Espíndola, Frederico Fábio Mauad pelo carinho de sempre e, sobretudo, pelo suporte acadêmico.

Ao Conselho Nacional de Desenvolvimento Científico e Tecnológico - CNPq pela bolsa de estudos concedida.

A Maria Sílvia Romitelli e Mayla Matsuzaki que não somente deram a mim a oportunidade de vivenciar o que neste trabalho foi estudado, como também são a mim exemplo de profissionais da SMA/DAIA.

A Vera Lúcia, Vagnólia e Beth que, de forma tão prestativa, viabilizaram as informações necessárias junto à Secretaria Estadual de Meio Ambiente - SMA/DAIA, sem as quais não seria possível a conclusão deste trabalho.

Agradeço aos meus pais (Celina e Zelão) pela atenção, carinho, paciência e apoio incondicionais em todos os momentos da minha vida e às minhas queridas irmãs e amigas Gi e Eli que sempre me apoiaram durante a graduação e durante todo o mestrado, e que me ensinaram, através do exemplo, a caminhar rumo à minha realização profissional.

Aos meus tios, Jurandir e Adelina, que se tornaram grandes amigos e que me acolheram de forma tão carinhosa em São Carlos, durante o mestrado.

Ao Ricardo pelos conselhos, incentivos e pela compreensão por tantas ausências minhas.

Agradeço às amigas: Dani Dellelo, Taty SantAna, Carol Cunha, Patrícia Giloni, Clara Lemos, Ângela Pelin pelos momentos de alegria e auxílio nos momentos de dificuldades, que de certa forma contribuíram no desenvolvimento deste trabalho.

E acima de tudo, agradeço a Deus. 


\section{RESUMO}

AGUILAR, G.T. (2008). Análise do tempo de tramitação de processos de licenciamento ambiental: estudo de casos de termelétricas no Estado de São Paulo. Dissertação (Mestrado) - Escola de Engenharia de São Carlos, Universidade de São Paulo, São Carlos, 2008.

Os procedimentos de licenciamento ambiental (LA) têm sido criticados pelos agentes econômicos, notadamente por aqueles ligados ao setor energético, por entenderem que a agilidade na análise dos processos de viabilidade ambiental de empreendimentos encontra-se aquém ao esperado. Com o objetivo de analisar a interferência de alguns fatores ligados aos procedimentos de LA sobre o tempo total de tramitação dos processos, foi realizada revisão documental de processos que tramitaram no estado de São Paulo, entre 1998 e 2007, para a instalação de usinas termelétricas a gás natural, com potência superior a $10 \mathrm{MW}$, e que obtiveram a licença ambiental prévia (LP). Foram obtidos dados quantitativos e informações qualitativas que permitiram verificar que os fatores "número de solicitações de informações complementares feitas pelos órgãos ambientais ao empreendedor", "número de impactos ambientais identificados no Estudo de Impacto Ambiental (EIA)" e "número de condicionantes constantes na LP expedida" não apresentam uma relação com o tempo de tramitação dos processos. Outros fatores como deficiências no estudo ambiental e a inadequação do local proposto à instalação dos empreendimentos, dadas as restrições ambientais, aparentemente apresentam maior interferência sobre os tempos de tramitação. Diante disto, destaca-se a necessidade de, previamente ao licenciamento, serem elaborados estudos específicos voltados à apresentação de alternativas locacionais que considerem critérios ambientais e critérios econômicos com o mesmo nível de importância para a tomada de decisão. Tais estudos, servindo como base de referência para a escolha da melhor localização para instalação de empreendimentos, tendem a reduzir o tempo total de tramitação dos processos de licenciamento.

Palavras-chave: licenciamento ambiental, avaliação de impacto ambiental, setor energético, termelétrica. 


\begin{abstract}
AGUILAR, G.T. (2008). Analysis of proceeding period on environmental licensing processes: a case study on thermal power plants in Sao Paulo State. M.Sc. Dissertation - Escola de Engenharia de São Carlos, Universidade de São Paulo, São Carlos, 2008.
\end{abstract}

The procedures for environmental licensing (LA) have been criticized by economic agents, especially by those connected to the energy sector, because they believe that agility on analysis of the processes of enterprises environmental viability is less than what was expected. In order to analyze the interference of some factors related to LA proceedings on proceeding period, the processes documentary review was held and transited in São Paulo State between 1998 and 2007 for the installation of natural gas thermal power plants with emitted preliminary environmental permit (LP) and output exceeding $10 \mathrm{MW}$. Quantitative data and qualitative information were obtained which allowed the confirmation that the factors "number of requests for additional information made by environmental agencies to the enterprise", "number of environmental impacts identified in the Environmental Impact Statement (EIA)" and "number of constraints in the LP emitted" have no relation to the proceeding period. Other factors such as shortcomings in the environmental study and inadequate the proposed site for the installation of enterprises, given the environmental restrictions, apparently show greater interference on the proceeding period. So, there is a necessity, prior to licensing, of being drawn up specific studies focused on the presentation of located alternatives to consider environmental and economic issues with the same level of importance for the decision. Such studies, serving as point of reference for choosing the best location for setting up of enterprises tend to reduce the proceeding period of the licensing processes.

Keywords: environmental licensing, environmental impact assessment, energy sector; thermal power plants. 


\section{LISTA DE FIGURAS}

Figura 2.1. Representação do procedimento de licenciamento ambiental com apresentação de RAP no âmbito do DAIA, conforme Resolução SMA 42/94 (adaptado

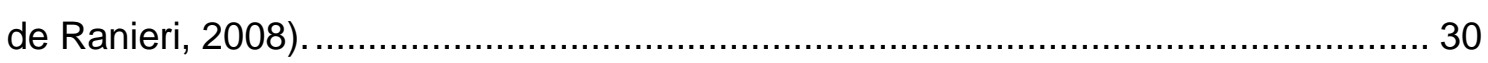

Figura 2.2. Representação do procedimento de licenciamento ambiental com apresentação de EIA/RIMA no âmbito do DAIA, conforme Resolução SMA 54/2004 (adaptado de Ranieri, 2008). 31

Figura 2.3. Matriz de Energia Elétrica 2023: Cenário Referência (adaptado de MME, 2006a). 34

Figura 2.4. Matriz de Energia Elétrica 2023: Cenário alternativo 1 (adaptado de MME, 2006a). 35

Figura 2.5. Matriz de Energia Elétrica 2023: Cenário alternativo 2 (adaptado de MME, 2006a). 35

Figura 2.6. Principais problemas enfrentados pela indústria no processo de Licenciamento (\%) (Fonte: CNI, 2007a).... 38

Figura 5.1. Localização proposta para implantação da UTE CCBS (extraído de Google Earth). 51

Figura 5.2. Tempo total de tramitação do processo SMA 13.698/1998. 53

Figura 5.3. Tempo total de tramitação em cada agente envolvido no processo SMA 13.698/1998. 53

Figura 5.4. Representação da tramitação do processo de licenciamento ambiental da UTE CCBS (SMA 13.698/1998). 55

Figura 5.5. Localização proposta para implantação da UTE Santa Branca (extraído de Google Earth). 60

Figura 5.6. Tempo total de tramitação do processo SMA 13.696/1999. 62

Figura 5.7. Tempo total de tramitação em cada agente envolvido no processo SMA 13.696/1999. 62

Figura 5.8. Representação da tramitação do processo de licenciamento ambiental da

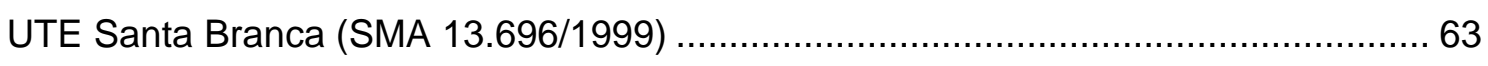

Figura 5.9. Área proposta para implantação da UTE Duke Energy 1 ...........................6 68 Figura 5.10. Proposta locacional para instalação da UTE Duke 1 (extraído de Google Earth). 68

Figura 5.11. Distribuição do tempo total de tramitação do processo SMA 13.629/2000 entre os dois principais grupos de agentes (empreendedor e órgãos governamentais). 
Figura 5.12. Tempo total de tramitação em cada agente envolvido no processo SMA 13.629/2000. .70

Figura 5.13. Representação da tramitação do processo de licenciamento ambiental da UTE Duke Energy 1 (SMA 13.629/2000). 71

Figura 5.14. Proposta locacional para instalação da UTE Carioba II próxima às manchas urbanas dos municípios de Americana e Santa Bárbara D'Oeste. .73

Figura 5.15. Alternativa locacional proposta em terreno pertencente à empresa Fibra (extraído de Google Earth) .74

Figura 5.16. Tempo total de tramitação do processo SMA 13.545/2000. .75

Figura 5.17. Tempo total de tramitação em cada agente envolvido no processo SMA $13.545 / 2000$. 76

Figura 5.18. Representação da tramitação do processo de licenciamento ambiental da UTE Carioba II (SMA 13.545/2000). .77

Figura 5.19. Localização proposta para implantação da UTE Araraquara (extraído de Google Earth). .83

Figura 5.20. Tempo total de tramitação do processo de licenciamento ambiental da UTE Araraquara. .85

Figura 5.21. Tempo total de tramitação em cada agente envolvido no processo. 85 Figura 5.22. Representação da tramitação do processo de licenciamento ambiental da

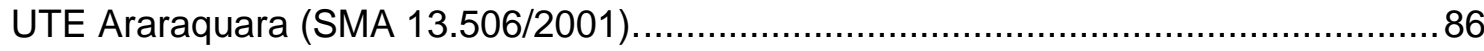

Figura 5.23. Representação da tramitação do processo SMA $13.734 / 2003$................. 86 Figura 5.24. Análise da relação entre o número de impactos ambientais identificados no EIA do empreendimento e o número de condicionantes constantes na LP. .90 Figura 5.25. Análise da relação entre o número de impactos ambientais e o tempo total de tramitação do processo. 91 Figura 5.26. Análise da relação entre o número de condicionantes constantes na LP e o tempo total de tramitação do processo. 91 Figura 5.27. Análise da relação entre o número de solicitações de informações complementares feitas pelos órgãos ambientais ao empreendedor e o tempo total de tramitação do processo. .93 Figura 5.28. Relação entre o tempo que independe do empreendedor e o tempo total de tramitação do processo. .95 Figura 5.29. Relação entre o tempo total de tramitação que depende do empreendedor e o tempo total de tramitação do processo. .95 Figura 5.30. Tempo de tramitação que independe do empreendedor em função do ano de início do processo (solicitação da LP). 96 


\section{LISTA DE QUADROS}

Quadro 2.1. Principais deficiências em Estudos de Impacto Ambiental (adaptado de MPF, (2004)).

Quadro 2.2. Alguns dos potenciais impactos ambientais decorrentes do planejamento,

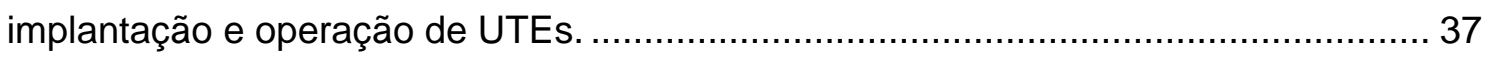

Quadro 5.1. Possíveis combinações entre o número de impactos identificados no EIA e o número de condicionantes exigidas pelos órgãos licenciadores. 46

Quadro 5.2. Processos de licenciamento ambiental que tramitaram no DAIA no período compreendido entre 1998 e 2007, mas não analisados neste estudo pois não resultaram na emissão de LP. 48

Quadro 5.3. Processos de licenciamento ambiental que tramitaram no DAIA no período compreendido entre 1998 e 2007 e resultaram na emissão de LP.................. 48

Quadro 5.4. Principais características da UTE CCBS.............................................. 50

Quadro 5.5. Principais características da UTE Santa Branca.................................. 59

Quadro 5.6. Principais características da UTE Duke Energy 1................................. 67

Quadro 5.7. Principais características da UTE Caroba II...................................... 72

Quadro 5.8. Principais características da UTE Araraquara..................................... 82

Quadro 5.9. Identificação das UTEs a gás natural, com potência instalada superior a $10 \mathrm{MW}$, que obtiveram LP no Estado de São Paulo e respectivo processo tramitado no

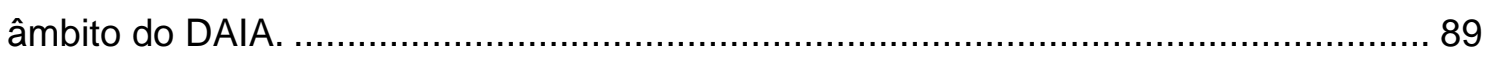




\section{LISTA DE TABELAS}

Tabela 2.1. Evolução da Demanda Total de Energia Elétrica Final (MWa)..... 33

Tabela 2.2. Detalhamento da Matriz Elétrica do cenário referência 2005 - 2023 (MWa)

Tabela 5.1. Caracterização do processo SMA 13.698/1998 frente aos fatores selecionados. .52

Tabela 5.2. Análise dos tempos de tramitação do processo SMA 13.698/1998. .53

Tabela 5.3. Caracterização do processo SMA 13.696/1999 frente aos fatores selecionados. 60

Tabela 5.4. Análise dos tempos de tramitação do processo SMA 13.696/1999. 61

Tabela 5.5. Caracterização do processo SMA 13.629/2000 frente aos fatores selecionados. 69

Tabela 5.6. Análise dos tempos de tramitação do processo SMA 13.629/2000. 69

Tabela 5.7. Caracterização do processo SMA $13.545 / 2000$ frente aos fatores selecionados. .74

Tabela 5.8. Análise dos tempos de tramitação do processo SMA 13.545/2000. .75

Tabela 5.9. Análise das alternativas locacionais sem a implantação da UTE Carioba II. 80

Tabela 5.10. Análise das alternativas locacionais com a implantação da UTE Carioba II. 80

Tabela 5.11. Caracterização dos processos SMA 13.506/2001 e SMA 13.734/2003 frente aos fatores selecionados. .84

Tabela 5.12. Análise dos tempos de tramitação dos processos SMA 13.506/2001 e SMA $13.734 / 2003$. 84

Tabela 5.13. Análise comparativa entre as alternativas locacionais propostas. 88

Tabela 5.14. Resultados das análises dos processos consultados. 89

Tabela 5.15. Discriminação do tempo total de tramitação dos processos. 94 


\section{LISTA DE SIGLAS E ABREVIATURAS}

\begin{tabular}{|c|c|}
\hline AIA & Avaliação de Impacto Ambiental \\
\hline ANEEL & Agência Nacional de Energia Elétrica \\
\hline APA & Área de Proteção Ambiental \\
\hline APP & Área de Preservação Permanente \\
\hline BNDES & Banco Nacional de Desenvolvimento Econômico e Social \\
\hline $\mathrm{CBH}$ & Comitê de Bacia Hidrográfica \\
\hline CCBS & Central de Cogeração da Baixada Santista \\
\hline CETESB & Companhia de Tecnologia de Saneamento Ambiental \\
\hline $\mathrm{CNI}$ & Confederação Nacional da Indústria \\
\hline CNPE & Conselho Nacional de Política Energética \\
\hline CONAMA & Conselho Nacional de Meio Ambiente \\
\hline CONDEMA & Conselho Municipal de Defesa do Meio Ambiente \\
\hline CONSEMA & Conselho Estadual do Meio Ambiente \\
\hline CPRN & $\begin{array}{l}\text { Coordenadoria de Licenciamento Ambiental e Proteção dos } \\
\text { Recursos Naturais }\end{array}$ \\
\hline DAIA & Departamento de Avaliação de Impacto Ambiental \\
\hline DEPRN & Departamento Estadual de Proteção aos Recursos Naturais \\
\hline EAS & Estudo Ambiental Simplificado \\
\hline EIA & Estudo de Impacto Ambiental \\
\hline IBAMA & $\begin{array}{l}\text { Instituto Brasileiro do Meio Ambiente e dos Recursos Naturais } \\
\text { Renováveis }\end{array}$ \\
\hline LI & Licença Ambiental de Instalação \\
\hline LO & Licença Ambiental de Operação \\
\hline LP & Licença Ambiental Prévia \\
\hline MME & Ministério de Minas e Energia \\
\hline NEPA & National Environment Policy Act \\
\hline ONG & Organização não-governamental \\
\hline PNMA & Política Nacional do Meio Ambiente \\
\hline PIB & Produto Interno Bruto \\
\hline PPT & Programa Prioritário de Termeletricidade \\
\hline RAP & Relatório Ambiental Preliminar \\
\hline RAS & Relatório Ambiental Simplificado \\
\hline RIMA & Relatório de Impacto Ambiental \\
\hline RPBC & Refinaria Presidente Bernardes de Cubatão \\
\hline SISNAMA & Sistema Nacional do Meio Ambiente \\
\hline
\end{tabular}


SMA Secretaria de Estado do Meio Ambiente

UHE Usina Hidrelétrica

UTE Usina Termelétrica 


\section{SUMÁRIO}

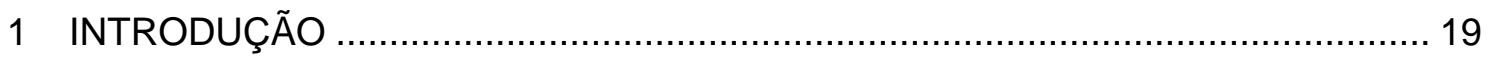

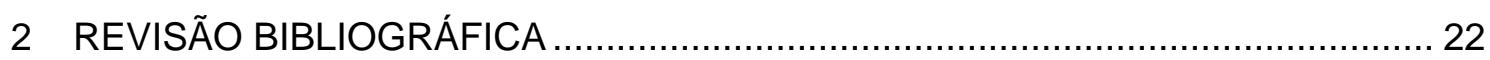

2.1 Licenciamento Ambiental e Avaliação de Impacto Ambiental ....................... 22

2.1.1 Procedimento para Licenciamento Ambiental no âmbito do DAIA .... 28

2.2 Setor elétrico e o Licenciamento Ambiental .............................................. 31

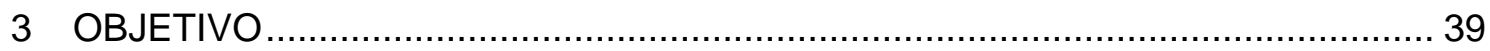

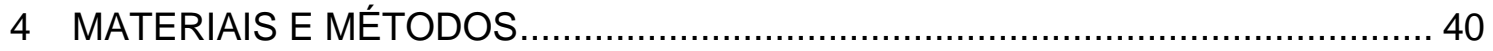

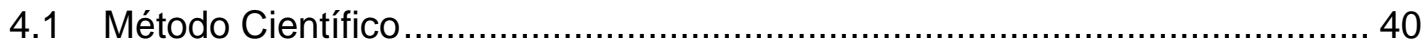

4.2 Descrição dos procedimentos adotados.............................................. 40

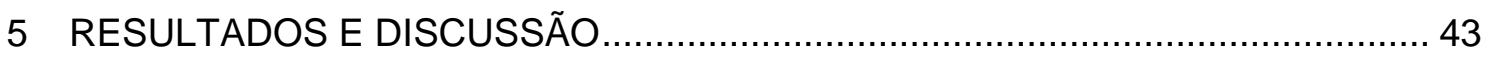

5.1 Identificação dos fatores que influenciam no tempo total de tramitação do processo de Licenciamento Ambiental ................................................................ 43

5.2 Caracterização dos empreendimentos e análise dos processos de licenciamento ambiental ........................................................................... 47

5.2.1 UTE Central de Cogeração da Baixada Santista - CCBS ................. 50

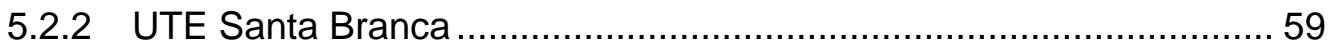

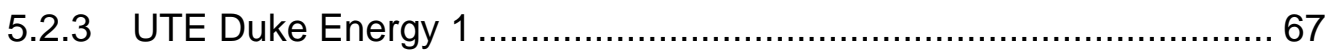

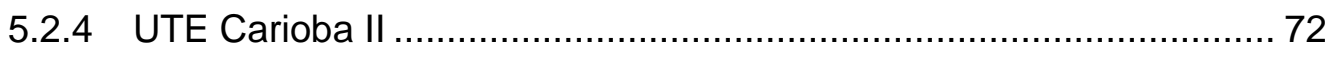

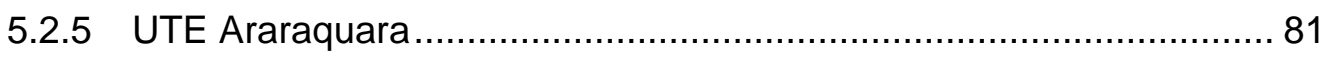

5.3 Análise comparativa entre os processos/empreendimentos consultados ..... 89

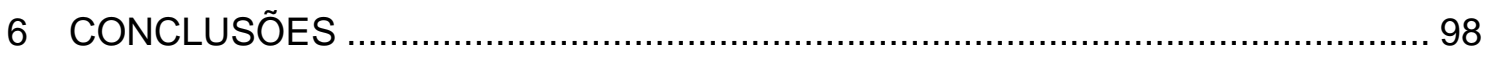

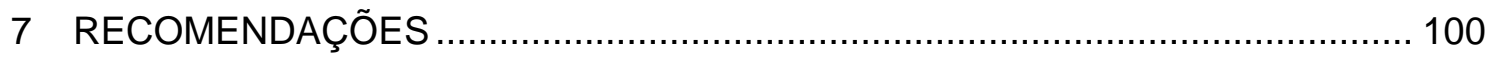

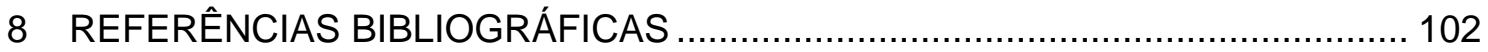

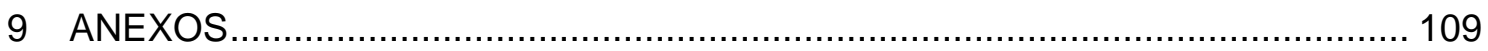




\section{INTRODUÇÃO}

Nos últimos anos, com a aceleração da economia nacional, o conseqüente aumento da demanda por energia, a redução de potenciais hidrelétricos em especial observada no estado de São Paulo, a disponibilidade de gás natural e as recentes descobertas em bacias brasileiras (EBC, 2008), se observa a tendência do crescimento da participação desse combustível fóssil na geração de energia elétrica em território nacional, anteriormente prevista por MME (2006b) e, conseqüentemente, o aumento no número de usinas termelétricas (UTEs) projetadas e implantadas.

De acordo com a Resolução CONAMA n $n^{0}$ 001/86, os empreendimentos de geração de energia, qualquer que seja a fonte, com potência instalada superior a 10 MW se enquadram entre as tipologias de empreendimentos que tem potencial de causar significativo impacto ambiental e que, portanto, devem passar pelo procedimento de licenciamento ambiental com apresentação de Estudo de Impacto Ambiental e respectivo Relatório de Impacto Ambiental (EIA/RIMA) (BRASIL, 1986).

O licenciamento ambiental é um dos instrumentos previstos na Política Nacional do Meio Ambiente (PNMA) (Lei $n^{\circ}$ 6.938/81) com o objetivo de promover a conciliação entre o desenvolvimento socioeconômico e a promoção da melhoria da qualidade ambiental (BRASIL, 1981). O EIA é o estudo técnico que subsidia a tomada de decisão sobre a viabilidade ambiental de um empreendimento no contexto da avaliação de impacto ambiental (AIA).

A AIA, que também está entre os instrumentos da PNMA, é o procedimento que consiste no conjunto concatenado de atividades voltadas para o exame das conseqüências futuras de uma ação proposta e, no Brasil, está diretamente vinculada ao licenciamento ambiental (SÁNCHEZ, 2006). Embora tenham se consolidado no país desde a década de 1980, muitos problemas são verificados para a efetiva implementação do licenciamento e da avaliação de impacto ambiental (GLASSON \& SALVADOR, 2000; SÁNCHEZ, 2006; SOUZA, 2000) e muita polêmica se verifica em torno desses instrumentos.

Boa parte da polêmica que envolve licenciamento e AIA gira em torno do tempo despendido para a análise dos processos de licenciamento, particularmente daqueles que incluem a apresentação e análise do EIA/RIMA. Ao contrário do licenciamento no qual podem ser adotados procedimentos e exigidos estudos 
simplificados, no caso do licenciamento com apresentação de EIA/RIMA os procedimentos normalmente têm tramitação mais longa, com análise mais detalhada dos impactos identificados e maior possibilidade de participação da sociedade por meio, por exemplo, de audiências públicas (SÁNCHEZ, 2006).

Empreendedores, sejam públicos ou privados, reclamam que as regras ambientais são muito rigorosas e que a morosidade dos procedimentos de licenciamento ambiental representa um "gargalo" que desestimula os investimentos (CNI, 2007a; PINHEIRO-PEDRO, 2006).

Os órgãos governamentais responsáveis pelo licenciamento, por sua vez, defendem-se argumentando que os procedimentos respeitam os prazos estabelecidos nas normas e que a demora se dá, em grande parte, devido à má qualidade dos estudos ambientais apresentados pelos empreendedores (ver, por exemplo, ASSOCIAÇÃO DOS SERVIDORES DO IBAMA-DF, 2004; MENDES \& FEITOSA, 2008).

Já a sociedade civil organizada, representada principalmente por Organizações não-governamentais (ONGs) dedicadas à defesa do meio ambiente, e também o Ministério Público defendem a análise criteriosa de todos os empreendimentos, o respeito às normas ambientais e também entendem que a baixa qualidade dos estudos ambientais compromete a eficiência dos procedimentos de licenciamento (MPF, 2004; O ESTADO DE SÃO PAULO, 2007).

Aparentemente preocupados com os atrasos na implantação dos empreendimentos de geração de energia decorrentes de "entraves" no licenciamento ambiental, investidores e a própria agência reguladora do setor elétrico (ANEEL) chegam a propor, inclusive, a dispensa dos procedimentos de licenciamento ambiental a empreendimentos considerados de "interesse social" (BESSA, 2007).

Nesse cenário de conflito de interesses e considerando as críticas feitas aos procedimentos de licenciamento ambiental, particularmente por empreendedores do setor elétrico (ver, por exemplo, COLLET, 2005), surge a pergunta: os fatores normalmente apontados como responsáveis pela demora nos procedimentos de licenciamento ambiental têm interferência nos tempos de tramitação dos processos? 
Este trabalho procura responder esta pergunta por meio de análise processual, tendo como recorte espaço-temporal os empreendimentos termelétricos a gás natural e potência instalada superior a $10 \mathrm{MW}$ propostos de serem implantados no Estado de São Paulo e licenciados no âmbito do Departamento de Avaliação de Impactos Ambientais (DAIA) entre os anos de 1998 e 2007. 


\section{REVISÃO BIBLIOGRÁFICA}

\subsection{Licenciamento Ambiental e Avaliação de Impacto Ambiental}

A Avaliação de Impacto Ambiental (AIA), segundo IAIA (1999) pode ser definida como um processo de identificação, previsão, avaliação e mitigação dos significativos efeitos sobre os meios físico, biótico e antrópico decorrentes de propostas de desenvolvimento.

Seguindo o mesmo princípio, Sánchez (2006), define a AIA como o "processo de exame das conseqüências futuras de uma ação presente ou proposta" (p. 43), processo este que consiste em um "conjunto de procedimentos concatenados de maneira lógica, com a finalidade de analisar a viabilidade ambiental de projetos, planos e programas, e fundamentar uma decisão a respeito" (p. 92). Segundo o mesmo autor, o procedimento completo de AIA, quando aplicado a empreendimentos, obras ou atividades (e não programas, planos e/ou, ainda, políticas) inclui as seguintes etapas:

a) apresentação da proposta por parte do interessado em levar adiante um empreendimento com potencial de causar impacto;

b) triagem, que consiste na determinação da necessidade, ou não, do projeto ser analisado com base na apresentação de um estudo ambiental detalhado em função do seu potencial em causar, ou não, significativo impacto ambiental;

c) determinação do escopo (abrangência e profundidade) do estudo a ser apresentado caso, na etapa de triagem, seja verificada a necessidade de elaboração de estudo ambiental detalhado;

d) elaboração do estudo ambiental detalhado por equipe multidisciplinar. Deve acompanhar o estudo técnico, um relatório com as principais características do empreendimento e seus impactos em linguagem acessível às pessoas possivelmente interessadas na proposta;

e) análise técnica do estudo ambiental detalhado por equipe(s) técnica(s) multidisciplinar(es) para verificar o cumprimento das normas legais e, fundamentalmente, se o empreendimento apresenta viabilidade ambiental. Normalmente tal análise é realizada pelo órgão (ou órgãos) do governo responsável pela autorização do empreendimento;

f) consulta pública aos interessados, que podem ser as pessoas diretamente ou indiretamente afetadas (ou potencialmente afetadas) pelo empreendimento proposto, mas não somente estas; 
g) decisão quanto à aprovação ou não do empreendimento face à análise técnica e às manifestações dos interessados, podendo a aprovação estar vinculada ao cumprimento de determinadas condicionantes. A decisão normalmente cabe ao mesmo órgão responsável pela análise técnica, mas, em alguns casos, pode ser delegada a outros agentes do sistema;

h) monitoramento e gestão ambiental, realizados pelo responsável pelo empreendimento, a fim de confirmar ou não as previsões constantes no estudo ambiental apresentado, assegurar a implementação da atividade de forma satisfatória e promover os ajustes e correções necessárias nos procedimentos;

i) acompanhamento do cumprimento dos compromissos assumidos pelo empreendedor por agentes independentes (órgãos do governo e/ou auditores);

j) documentação do processo a fim de cumprir as exigências legais.

A AIA, como instrumento de política pública - cujo histórico se inicia nos Estados Unidos com a promulgação da National Environment Policy Act (NEPA) em 1969 -, foi incorporada à legislação brasileira por meio da Lei 6.938/81 (BRASIL, 1981) que instituiu a Política Nacional do Meio Ambiente (PNMA). Por meio desta lei também foram definidos outros instrumentos da PNMA, dentre os quais o zoneamento ambiental, e de uma forma geral observa-se que, atualmente, ainda existem muitos problemas que impossibilitam a efetiva implementação desses instrumentos em cenário nacional (GLASSON; SALVADOR, 2000; SÁNCHEZ, 2006; SOUZA, 2000) e, em especial, se verifica muita polêmica em torno do licenciamento e da avaliação de impacto ambiental.

A regulamentação do instrumento AIA para o procedimento de análise de empreendimentos com potencial de causar significativa degradação ambiental foi feita no Brasil pelo Conselho Nacional de Meio Ambiente (CONAMA), órgão consultivo e deliberativo do Sistema Nacional do Meio Ambiente (SISNAMA), por meio da Resolução CONAMA nº 001/86. Para tais empreendimentos, elencados no artigo $2^{\circ}$ da referida Resolução, é exigida a elaboração do chamado Estudo de Impacto Ambiental (EIA) e seu respectivo Relatório de Impacto Ambiental (RIMA), a serem apresentados por ocasião da solicitação de licença ambiental prévia por parte do empreendedor.

O EIA (que corresponde ao "estudo ambiental detalhado" citado anteriormente) deve contemplar, entre outros aspectos, a caracterização do empreendimento, a justificativa da escolha da alternativa tecnológica e locacional do empreendimento frente a todas as alternativas possíveis, o diagnóstico ambiental da área de influência 
do empreendimento, a análise dos impactos ambientais previstos, a proposição de medidas mitigadoras e compensatórias, e a descrição dos programas de acompanhamento e monitoramento dos impactos (BRASIL, 1986).

É interessante comentar que, nos países em desenvolvimento, a adoção da AIA deveu-se inicialmente à atuação das agências bi e multilaterais de fomento ao desenvolvimento. Notadamente no Brasil, os primeiros EIAs foram elaborados a fim de subsidiarem a aprovação dos financiamentos solicitados ao Banco Mundial para os projetos das barragens de Sobradinho no rio São Francisco, em 1972 (MOREIRA, 1988), e Tucuruí no rio Tocantins, em 1977 (1 ano após o início das obras) (MONOSOWSKI, 1990). Estes estudos somente foram utilizados pelo Banco Mundial para subsidiarem as condições de empréstimo e não foram submetidos à aprovação governamental brasileira, uma vez que ainda não eram exigidos legalmente.

Embora os procedimentos de licenciamento ambiental já existissem em vários estados brasileiros desde as décadas de 70 e 80, tal instrumento da PNMA só foi regulamentado para todo o país por meio da Resolução CONAMA n 237 de 19 de dezembro de 1997 (BRASIL, 1997b). Trata-se de um instrumento que promove a interface entre o empreendedor, cuja atividade pode vir a interferir sobre o meio ambiente, e o Estado, que deve atuar no sentido de exigir que os empreendimentos/atividades sejam implantados em conformidade com os objetivos dispostos na política estabelecida.

No artigo $1^{\circ}$ da Resolução CONAMA 237/97, o licenciamento ambiental é definido como:

[...] procedimento administrativo pelo qual o órgão ambiental competente licencia a localização, instalação, ampliação e a operação de empreendimentos e atividades utilizadoras de recursos ambientais, consideradas efetiva ou potencialmente poluidoras ou daquelas que, sob qualquer forma, possam causar degradação ambiental, considerando as disposições legais e as normas técnicas aplicáveis ao caso (BRASIL, 1997b).

No anexo I desta Resolução constam as atividades e empreendimentos sujeitos ao licenciamento ambiental. A produção de energia termelétrica encontra-se listada como serviço de utilidade e, portanto, está sujeita ao licenciamento ambiental. 
Em 2001, influenciado pela crise energética que o país enfrentava (evento conhecido popularmente como "Apagão"), o CONAMA, por meio da Resolução 279/01, estabeleceu um procedimento simplificado para o licenciamento de empreendimentos elétricos e sistemas de transmissão de energia elétrica (linhas de transmissão e subestações) que apresentem pequeno potencial de impacto ambiental (BRASIL, 2001).

Tal Resolução determina que o licenciamento ambiental de empreendimentos elétricos potencialmente causadores de baixo impacto ambiental deverá obedecer a um procedimento simplificado, mediante a apresentação de um Relatório Ambiental Simplificado (RAS) e com prazo máximo de tramitação de sessenta dias para cada fase, contados a partir da data de protocolização do requerimento das respectivas licenças, a saber: Licença Ambiental Prévia (LP), Licença Ambiental de Instalação (LI) e Licença Ambiental de Operação (LO).

Com a entrada em vigor da Resolução 279/01, o órgão ambiental competente, com base no RAS e mediante decisão fundamentada em parecer técnico, passou a ter poderes para definir se cada empreendimento enquadra-se ou não na categoria de causador de baixo impacto ambiental, e, conseqüentemente, para exigir ou dispensar a apresentação de EIA/RIMA.

Seguindo a linha das normas federais, no Estado de São Paulo o licenciamento ambiental é previsto para execução de obras, atividades, processos produtivos e empreendimentos e para a exploração de recursos naturais de qualquer espécie, quer pelo setor público, quer pelo privado (SÃO PAULO, 1989).

A análise dos pedidos de LP de empreendimentos termelétricos com potência superior a $10 \mathrm{MW}$, propostos para serem implantados no estado de São Paulo, compete ao Departamento de Avaliação de Impacto Ambiental (DAIA), órgão ambiental vinculado à Secretaria de Estado do Meio Ambiente (SMA), enquanto que todo o procedimento subseqüente, para análise e emissão de LI e LO, é de competência da Companhia de Tecnologia de Saneamento Ambiental (CETESB).

Assim como observado na esfera federal, e até anteriormente à Resolução 279/01, no estado de São Paulo também são adotados procedimentos simplificados de licenciamento ambiental. Desde 1994 existe a figura do Relatório Ambiental Preliminar (RAP) (SÃO PAULO, 1994), com função semelhante ao mencionado RAS, 
e, mais recentemente com a promulgação da Resolução SMA 54/04, além do RAP foi instituído o Estudo Ambiental Simplificado (EAS), para fundamentar o licenciamento de empreendimentos considerados de impacto ambiental não significativo (SÃO PAULO, 2004). ${ }^{1}$

Em que pesem as controvérsias a respeito da utilização de estudos simplificados (ver discussão aprofundada sobre o tema em Fortunato Neto, 2004), é seguro afirmar que, independente do grau de simplificação do estudo apresentado pelo empreendedor, devem ser abordados critérios ambientais mínimos, como diagnóstico e prognóstico ambiental, diretrizes municipais e estaduais de uso e ocupação do solo, análise dos impactos ambientais e medidas mitigadoras associadas, entre outros, de forma a subsidiar a análise de viabilidade ambiental do empreendimento feita pelo órgão competente.

Aguilar (2006) enfatiza que a análise de estudos ambientais, feita pelos técnicos responsáveis pelo licenciamento ambiental, tem por objetivo não somente verificar o cumprimento das Resoluções CONAMA 001/86 e 237/97 e de outros instrumentos de gestão ambiental pertinentes, mas também identificar falhas e omissões no estudo apresentado e sugerir correções.

Segundo MPF (2004), diversos EIAs elaborados com o intuito de licenciar atividades potencialmente degradadoras do ambiente apresentam grandes deficiências no que diz respeito à utilização de metodologias apropriadas e ao cumprimento e detalhamento de pesquisas e análises necessárias. No Quadro 2.1 são listadas algumas das principais deficiências encontradas nos EIAs, segundo o levantamento realizado pelo Ministério Público Federal.

1 Conforme estabelecido pela Resolução SMA 42/94, a partir de 1995 e até a promulgação da Resolução SMA 54/04, o RAP foi instituído no estado de São Paulo como estudo de apresentação obrigatória para todos os empreendimentos com potencial de causar impacto ambiental e servia como base para auxiliar o órgão ambiental (DAIA) a proceder a etapa de "triagem". Com base no RAP, o DAIA concluía pela necessidade, ou não, de apresentação do EIA/RIMA caso a caso, independentemente da tipologia do empreendimento em questão estar listada na Resolução CONAMA 001/86 entre aquelas para as quais deveria ser exigido EIA/RIMA. Após a promulgação da Resolução SMA 54/04, a etapa de triagem é feita por meio de consulta do empreendedor ao DAIA que define qual o estudo ambiental deve ser apresentado pelo interessado: EAS, RAP ou EIA/RIMA. 


\begin{tabular}{|c|c|}
\hline Etapa do EIA & Exemplos de deficiências encontradas nos EIAs \\
\hline \multirow[b]{2}{*}{ Termo de Referência } & Ausência de pesquisas e análises requeridas \\
\hline & $\begin{array}{l}\text { Recomendações repassadas às etapas posteriores à emissão } \\
\text { da LP como condicionantes das demais licenças }\end{array}$ \\
\hline \multirow{2}{*}{$\begin{array}{l}\text { Objetivos do } \\
\text { empreendimento }\end{array}$} & $\begin{array}{l}\text { Adoção dos objetivos do conjunto total de obras } \\
\text { interdependentes como justificativa para a aprovação de apenas } \\
\text { um dos trechos ou um dos projetos }\end{array}$ \\
\hline & $\begin{array}{l}\text { Omissão, ou descrição superficial, da relação do projeto } \\
\text { específico com o conjunto de obras ao qual se filia, } \\
\text { possibilitando a conclusão pela sua independência }\end{array}$ \\
\hline \multirow{4}{*}{$\begin{array}{l}\text { Estudo de alternativas } \\
\text { tecnológicas e } \\
\text { locacionais }\end{array}$} & Ausência de proposição de alternativas locacionais \\
\hline & $\begin{array}{l}\text { Apresentação de alternativas reconhecidamente inferiores à } \\
\text { selecionada no EIA }\end{array}$ \\
\hline & $\begin{array}{l}\text { Prevalência dos aspectos econômicos sobre os ambientais na } \\
\text { escolha das alternativas }\end{array}$ \\
\hline & $\begin{array}{l}\text { Comparação de alternativas a partir de base de conhecimento } \\
\text { diferenciada }\end{array}$ \\
\hline \multirow[b]{2}{*}{$\begin{array}{l}\text { Delimitação das áreas } \\
\text { de influência }\end{array}$} & Desconsideração da bacia hidrográfica como recorte de análise \\
\hline & $\begin{array}{l}\text { Desconsideração das características e vulnerabilidades dos } \\
\text { ambientes naturais e das realidades sociais regionais }\end{array}$ \\
\hline \multirow{6}{*}{ Diagnóstico Ambiental } & Prazos insuficientes para a realização de pesquisas de campo \\
\hline & $\begin{array}{l}\text { Caracterização da área baseada, predominantemente, em } \\
\text { dados secundários e bibliografias antigas }\end{array}$ \\
\hline & $\begin{array}{l}\text { Ausência ou insuficiência de informações sobre a metodologia } \\
\text { utilizada }\end{array}$ \\
\hline & $\begin{array}{l}\text { Proposição de diagnóstico em etapas do licenciamento } \\
\text { posteriores à Licença Prévia }\end{array}$ \\
\hline & Pesquisas insuficientes quanto aos aspectos socioculturais \\
\hline & Ausência de mapas temáticos ou mapas desatualizados \\
\hline \multirow{4}{*}{$\begin{array}{l}\text { Identificação, } \\
\text { caracterização e } \\
\text { análise de impactos }\end{array}$} & Não identificação de determinados impactos \\
\hline & Indicação de impactos genéricos e/ou mutuamente excludentes \\
\hline & $\begin{array}{l}\text { Tendência à minimização ou subestimação dos impactos } \\
\text { negativos e supervalorização dos impactos positivos }\end{array}$ \\
\hline & $\begin{array}{l}\text { Ausência de análise da cumulatividade e sinergia dos impactos } \\
\text { ambientais }\end{array}$ \\
\hline \multirow{4}{*}{$\begin{array}{l}\text { Mitigação e } \\
\text { compensação de } \\
\text { impactos }\end{array}$} & $\begin{array}{l}\text { Proposição de medidas mitigadoras inadequadas ou pouco } \\
\text { detalhadas }\end{array}$ \\
\hline & $\begin{array}{l}\text { Indicação de obrigações ou impedimentos técnicos e legais } \\
\text { como propostas de medidas mitigadoras }\end{array}$ \\
\hline & $\begin{array}{l}\text { Ausência de avaliação da eficiência das medidas mitigadoras } \\
\text { propostas }\end{array}$ \\
\hline & $\begin{array}{l}\text { Proposição de Unidade de Conservação em casos não previstos } \\
\text { pela legislação }\end{array}$ \\
\hline \multirow{2}{*}{$\begin{array}{l}\text { Programas de } \\
\text { monitoramento } \\
\text { ambiental }\end{array}$} & $\begin{array}{l}\text { Ausência de proposição de programa de monitoramento de } \\
\text { impactos específicos }\end{array}$ \\
\hline & Proposição de monitoramento insuficiente \\
\hline
\end{tabular}

Quadro 2.1. Principais deficiências em Estudos de Impacto Ambiental (adaptado de MPF, (2004)). 
A má qualidade dos estudos ambientais costuma ser apontada como um dos principais problemas relativos aos procedimentos de AIA (ASSOCIAÇÃO DOS SERVIDORES DO IBAMA-DF, 2004; MENDES \& FEITOSA, 2008). Estudos mal elaborados dificultam a análise dos impactos por parte dos órgãos responsáveis pelo licenciamento e tendem a tornar mais demorados os procedimentos de avaliação da viabilidade ambiental dos empreendimentos por parte de tais órgãos. Isto porque, havendo dúvida quanto à informação prestada no EIA, cabe ao órgão ambiental solicitar esclarecimentos e estudos complementares que lhe permitam tomar uma decisão segura.

Antes, porém, de discutir a qualidade dos estudos ambientais apresentados pelos empreendedores, é importante, considerando os objetivos desta pesquisa, demonstrar os procedimentos adotados pelo órgão ambiental do estado de São Paulo responsável pelo licenciamento ambiental de atividades potencialmente causadoras de significativo impacto ambiental, entre as quais encontram-se os empreendimentos termelétricos com potência instalada superior a $10 \mathrm{MW}$.

\subsubsection{Procedimento para Licenciamento Ambiental no âmbito do DAIA}

O DAIA, órgão vinculado à Secretaria Estadual de Meio Ambiente (SMA), é responsável pela análise dos pedidos de licença ambiental prévia de empreendimentos potencialmente ou efetivamente causadores de significativo impacto ambiental propostos para serem instalados no estado de São Paulo, dentre os quais encontram-se as usinas termelétricas com potência instalada superior a $10 \mathrm{MW}$, passíveis de licenciamento ambiental com apresentação de EIA/RIMA e foco principal deste estudo.

Dentre os processos analisados neste estudo, os que tramitaram entre 1998 e 2003 foram conduzidos com base na Resolução SMA 42/94 (Anexo 1) e, portanto, iniciaram-se com a apresentação de RAP, o qual servia como base de informações para subsidiar a análise do DAIA sobre a necessidade ou não de apresentação de EIA/RIMA. No entanto, nota-se que, mesmo após a promulgação da Resolução SMA 54/04 (Anexo 2) os processos continuaram sendo iniciados com a apresentação de RAP, conforme pode ser observado nos processos analisados neste estudo que tramitaram após 2004, para, após parecer técnico, ser solicitado apresentação de EIA/RIMA, em conformidade com a Resolução CONAMA 001/86, uma vez que os 
empreendimentos termelétricos com potência instalada superior a 10MW encontramse dentre aqueles para os quais é exigido EIA/RIMA.

Atualmente, o DAIA manifesta-se sobre a necessidade ou não de apresentação de EIA/RIMA em momento prévio quando o empreendedor protocoliza informações sucintas sobre o empreendimento na forma de consulta, o que proporciona maior agilidade ao processo, uma vez que não há necessidade de o empreendedor elaborar um estudo ambiental.

É importante comentar que as atividades passíveis de licenciamento ambiental com apresentação de EIA/RIMA listadas no Art. $2^{\circ}$ da Resolução CONAMA 001/86 têm caráter exemplificativo, e não taxativo, uma vez que, a própria Resolução SMA $42 / 94$ introduziu a possibilidade do processo de licenciamento ambiental ser simplificado se forem verificadas atividades que, apesar de constarem na referida Resolução, não forem consideradas potencialmente causadoras de significativa degradação ambiental, de acordo com a tipologia, porte e localização proposta para ser instalada. Nestes casos adota-se a apresentação de RAP para subsidiar a avaliação do órgão público sobre a viabilidade ambiental do empreendimento/atividade, estudo menos complexo e que cujas exigências legais de audiência pública e compensação ambiental não se aplicam.

Em linhas gerais, os procedimentos para o licenciamento ambiental no âmbito do DAIA encontram-se, atualmente, regulamentados por meio da Resolução SMA 54/2004 (Figura 2.2), no entanto, a Resolução SMA 42/94 (Figura 2.1) não encontra-se revogada e esta é adotada nos casos em que o licenciamento ambiental pode ser conduzido por meio de apresentação de RAP, quando assim a equipe técnica julgar, de acordo com o porte do empreendimento e o potencial de causar significativos impactos ambientais negativos. Sabe-se, porém, que para cada tipologia de empreendimento este procedimento pode apresentar algumas variações no que diz respeito aos órgãos a serem consultados para manifestação acerca de determinado aspecto ou impacto ambiental.

No procedimento específico de licenciamento de usinas termelétricas, tipologia em que potencialmente são observados aspectos como emissão de efluentes gasosos, geração de resíduos sólidos, demanda por recurso hídrico, supressão de vegetação, possível intervenção em Área de Preservação Permanente (APP) e em Unidades de Conservação, são solicitadas manifestações de alguns órgãos internos e 
outros externos ao sistema, a saber, Cetesb, Comitê de Bacia Hidrográfica (CBH), Departamento Estadual de Proteção aos Recursos Naturais (DEPRN), Fundação Florestal, dentre outros.

Considerando as manifestações dos órgãos demandados, o DAIA emite um parecer técnico o qual é submetido ao Conselho Estadual do Meio Ambiente (Consema), e que, em caso de aprovação deste, é emitida a LP requerida, fixando prazo de validade e condicionantes para as fases subseqüentes. A continuidade do licenciamento ambiental, ou seja, o licenciamento ambiental para as fases de implantação e operação da usina ocorre no âmbito da Cetesb.

\section{Procedimento Licenciamento Ambiental conforme Resolução SMA 42/94}

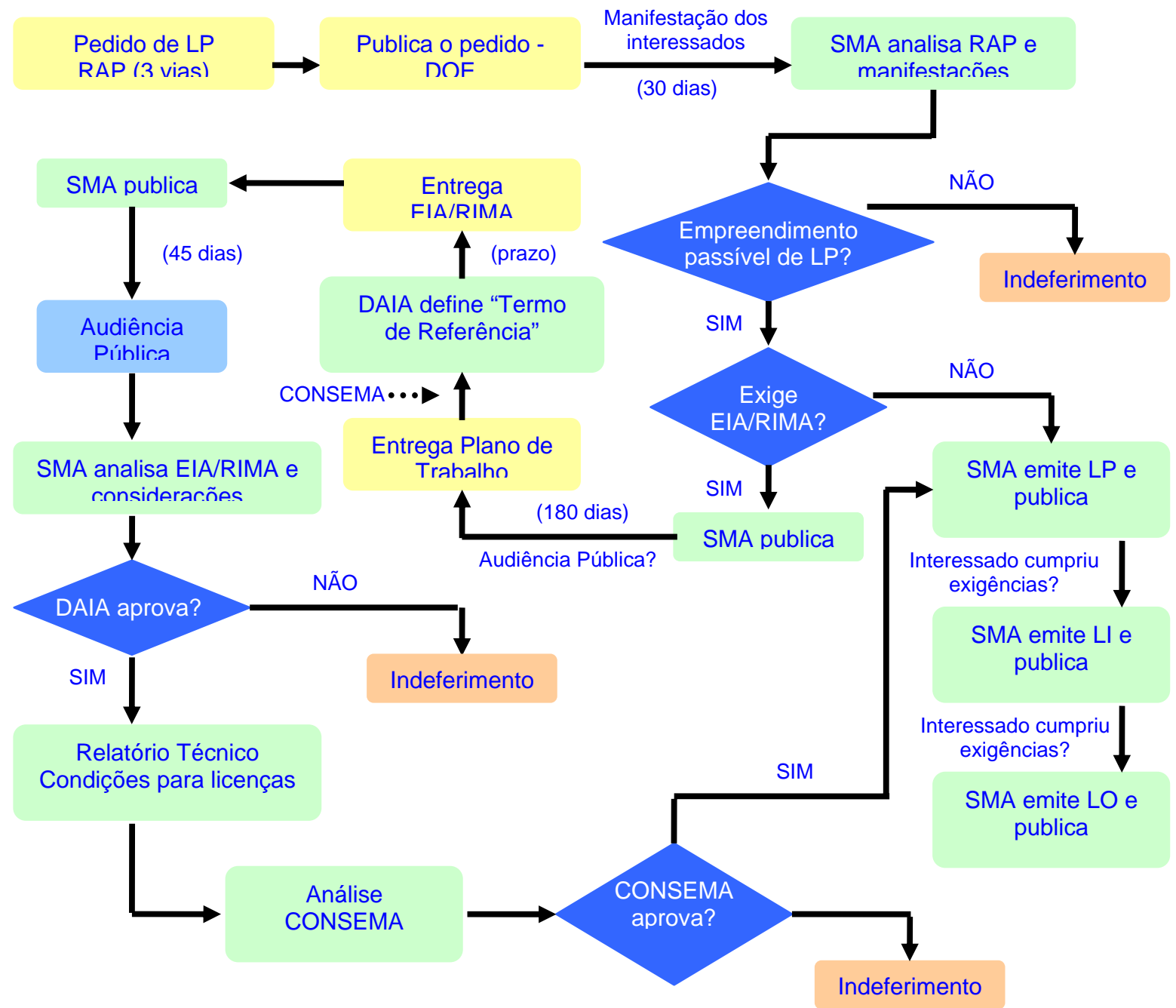

Figura 2.1. Representação do procedimento de licenciamento ambiental com apresentação de RAP no âmbito do DAIA, conforme Resolução SMA $42 / 94$ (adaptado de Ranieri, 2008). 


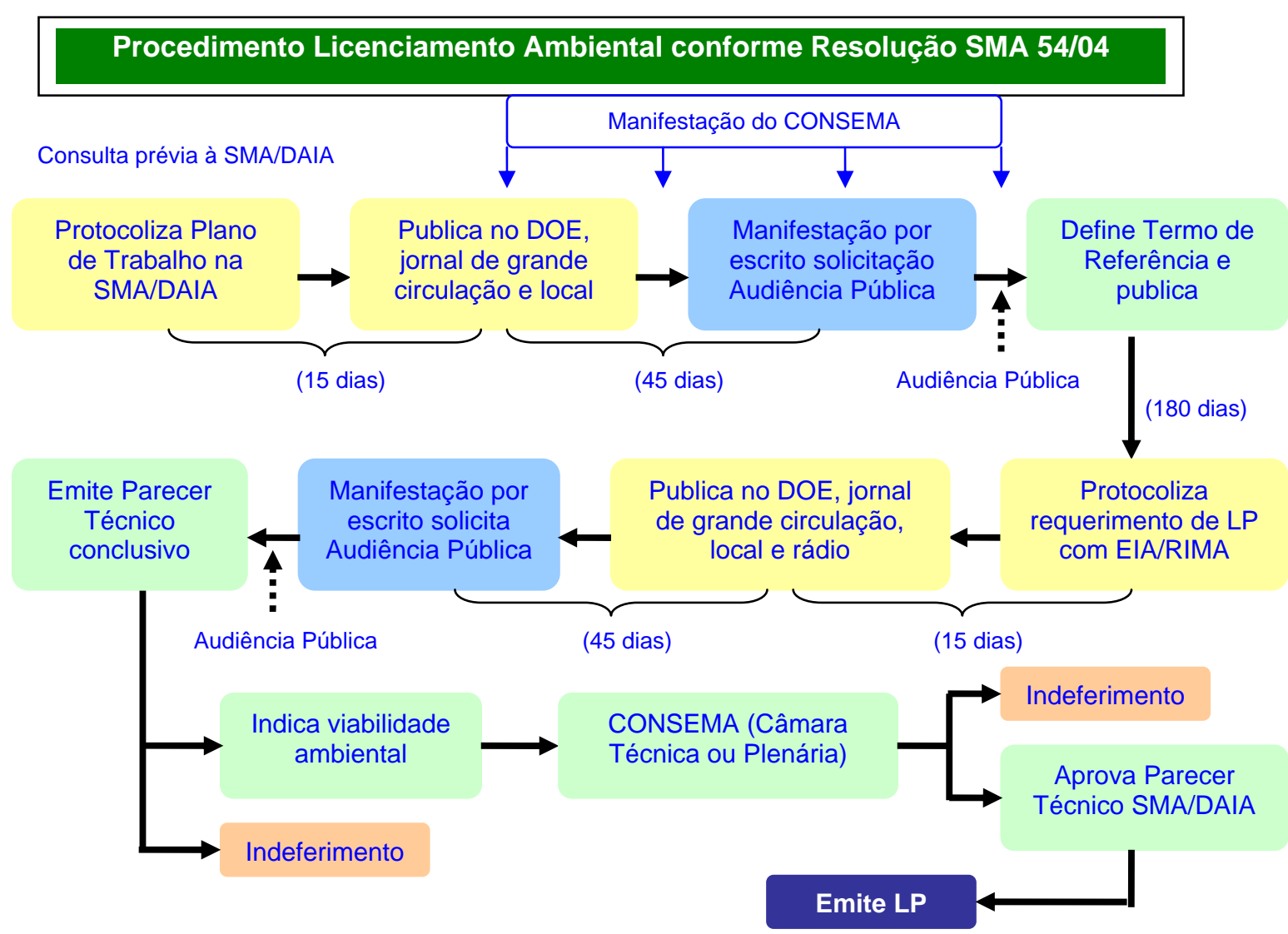

Figura 2.2. Representação do procedimento de licenciamento ambiental com apresentação de EIA/RIMA no âmbito do DAIA, conforme Resolução SMA 54/2004 (adaptado de Ranieri, 2008).

\subsection{Setor elétrico e o Licenciamento Ambiental}

Devido ao grande potencial hídrico, a matriz energética brasileira baseia-se na geração de energia elétrica a partir de aproveitamentos hidráulicos que corresponde, atualmente, a 75,98\% do potencial total instalado. De acordo com o Balanço Energético Nacional - 2007, o parque gerador de eletricidade aumentou de $11 \mathrm{GW}$ em 1970 para 96,6 GW em 2006, sendo, portanto, a capacidade instalada hidráulica de 73,4 GW (MME, 2007).

A partir de meados da década de 1990, com o reaquecimento da economia brasileira, o setor de geração de energia elétrica passou a operar com capacidade máxima em tempo integral, o que baixou os níveis dos reservatórios a índices críticos. No ano de 2001 o Brasil vivenciou uma crise no setor elétrico, evidenciando assim a escassez de investimentos aliada ao crescente nível no consumo, motivado pela estabilização econômica (LOURENÇO, 2003). 
Em decorrência da crise que se iniciou no final da década de 90, e que, segundo Guadagnini (2006), levou a um risco de desabastecimento que atingiu aproximadamente 20\% (bem acima dos 5\% aceitos internacionalmente), o cenário energético nacional mostrou-se favorável à implantação de um Programa do Ministério de Minas e Energia, o Programa Prioritário de Termeletricidade (PPT), instituído pelo Decreto $\mathrm{n}^{\circ} 3.371$ de 24 de fevereiro de 2000 (BRASIL, 2000).

O PPT, anunciado como a solução para se evitar uma crise energética a curto prazo, previa a construção de 49 usinas em todo país até 2003, a maioria delas utilizando gás natural como fonte primária, que gerariam juntas 15 mil MW/h.

As usinas termelétricas integrantes do PPT passaram a fazer jus a prerrogativas como garantia de suprimento de gás natural pelo prazo de até 20 anos, aos empreendimentos que começassem a operar até 2004, e garantia de acesso a programas de apoio financeiro pelo Banco Nacional de Desenvolvimento Econômico e Social (BNDES) (BRASIL, 2000a).

Desde 1997, com a Lei 9.478/97 (BRASIL, 1997a), ficou estabelecido como uma das atribuições do Conselho Nacional de Política Energética (CNPE), rever periodicamente a matriz energética nacional, sendo esta, segundo o estudo "Projeção da Matriz Energética Nacional 2005 - 2023" (MME, 2006a), um instrumento econômico privilegiado para a simulação de diferentes cenários de mercado e avaliação de seus efeitos.

A partir de então, a periodicidade da revisão tornou-se uma imposição legal cujo objetivo principal é, por meio de projeções da matriz energética, simular os efeitos de eventuais políticas energéticas, dentre eles, gargalos de infra-estrutura, vulnerabilidades sistêmicas, riscos ambientais, impactos em outras políticas públicas e, sobretudo, na inovação tecnológica, estrutura econômica e no padrão de consumo dos indivíduos (MME, 2006a).

Apoiando-se em cenários macro-setoriais de longo prazo (agropecuário, indústrias e serviços) e utilizando-se de taxas de crescimento macroeconômicas (dentre as quais Produto Interno Bruto (PIB); oferta interna de carvão, de energia nuclear, de hidrocarbonetos e de hidreletricidade) foi projetado um cenário referência 2005 - 2023 de crescimento para a economia brasileira (MME, 2006a) e analisadas, a partir dele, a evolução da demanda de energia elétrica no Brasil (Tabela 2.1) e a 
composição dos parques de geração ao longo do horizonte, denominado cenário referência (Tabela 2.2).

Tabela 2.1. Evolução da Demanda Total de Energia Elétrica Final (MWa)

\begin{tabular}{cccccc}
\hline Ano & $\mathbf{2 0 0 5}$ & $\mathbf{2 0 1 0}$ & $\mathbf{2 0 1 5}$ & $\mathbf{2 0 2 0}$ & $\mathbf{2 0 2 3}$ \\
\hline Total & 45.010 & 58.200 & 73.240 & 92.260 & 103.340 \\
\hline Taxa Anual \% & 5,3 & 4,7 & 4,7 & 3,9 \\
\hline Fonte: MME (2006a) & & & &
\end{tabular}

Tabela 2.2. Detalhamento da Matriz Elétrica do cenário referência 2005 - 2023 (MWa)

\begin{tabular}{|c|c|c|c|c|c|c|c|c|}
\hline & 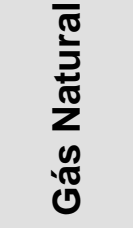 & 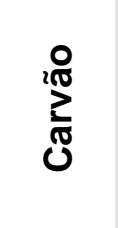 & 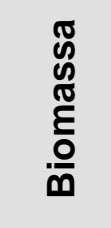 & 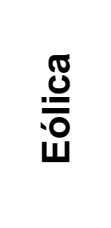 & 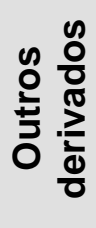 & $\frac{\frac{\pi}{0}}{\frac{0}{0}}$ & 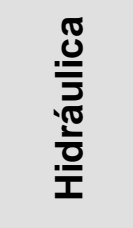 & 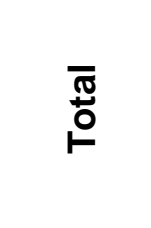 \\
\hline 2005 & 4.335 & 918 & 1.541 & 270 & 908 & 1.723 & 37.686 & 47.382 \\
\hline 2010 & 6.126 & 1.608 & 2.936 & 800 & 758 & 1.724 & 47.354 & 61.305 \\
\hline 2015 & 8.016 & 4.184 & 3.707 & 1.121 & 437 & 2.875 & 57.010 & 77.352 \\
\hline 2020 & 12.242 & 5.850 & 4.596 & 1.364 & 445 & 2.875 & 69.981 & 97.353 \\
\hline 2023 & 14.183 & 5.850 & 5.393 & 1.767 & 477 & 4.026 & 77.568 & 109.263 \\
\hline
\end{tabular}

MME (2006a) salienta que "o cenário adotado como referência apresenta características de um cenário tendencial, ou seja, não considera, no período enfocado, maiores transformações qualitativas na trajetória produtiva do país além daquelas já delineadas nos últimos anos".

Pode-se notar por meio da Tabela 2.2 e da Figura 2.3, os quais representam o cenário referência, que a participação das usinas hidrelétricas na produção de energia elétrica reduz de 79,5\% em 2005 para 71,0\% em 2023. Por outro lado, ressalta-se 0 crescimento da participação de termelétricas a gás natural, com valores de 9,1\% em 2005 para 13,0\% em 2013, e termelétricas a carvão, estimando-se a inclusão de carvão importado a partir de 2015.

A partir deste cenário referência foram elaborados três cenários alternativos, conforme descrito:

Cenário 1: cenário onde foi considerada a substituição, em relação ao cenário referência, de todo carvão importado e uma usina nuclear por uma maior participação das usinas termelétricas a gás. Neste cenário a geração de energia elétrica a partir de gás natural aumenta em 21\% (Figura 2.4); 
Cenário 2: cenário com substituição, em relação ao cenário referência, de todo carvão importado, uma usina nuclear e 6.500 MW de potência instalada de energia hidráulica por uma maior participação das usinas termelétricas a gás. Neste cenário a geração de energia elétrica a partir de gás natural aumenta em 44\% (Figura 2.5);

Cenário 3: neste cenário buscou-se uma maior exploração do potencial hidroelétrico da Amazônia, postergando o programa de expansão térmico. Assim, substituíram-se do cenário de referência, as usinas termelétricas a carvão importado, uma usina nuclear e parcelas da expansão das termelétricas a carvão nacional e a gás natural por uma maior participação de usinas hidrelétricas.

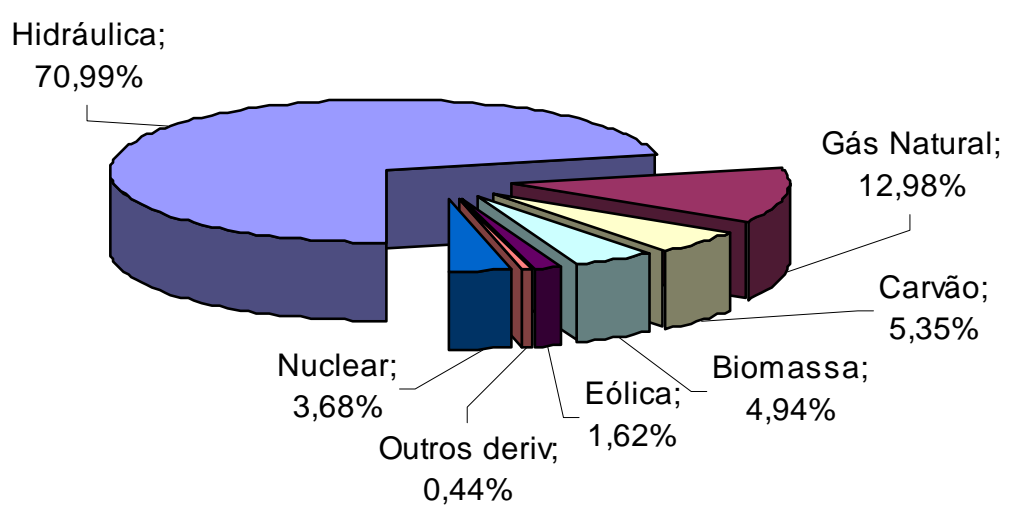

Figura 2.3. Matriz de Energia Elétrica 2023: Cenário Referência (adaptado de MME, 2006a).

As recentes descobertas de gás natural, as quais somam-se 364,9 bilhões de metros cúbicos (EBC, 2008), confirmam as perspectivas dos resultados dos cenários de projeção da matriz energética para o ano de 2023 e as anteriormente apontadas por Horta Nogueira (2001) de que o gás natural permaneceria desempenhando um papel relevante na matriz energética, e com isso espera-se um importante incremento no uso da geração térmica. 


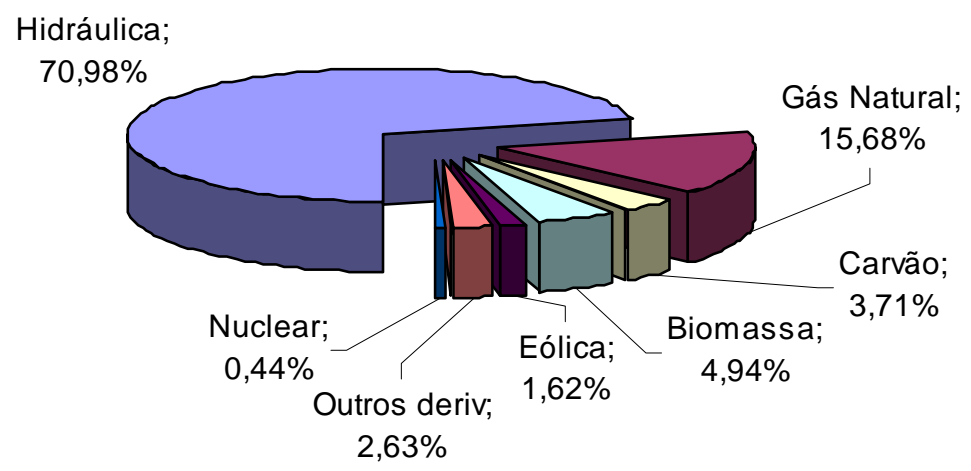

Figura 2.4. Matriz de Energia Elétrica 2023: Cenário alternativo 1 (adaptado de MME, 2006a).

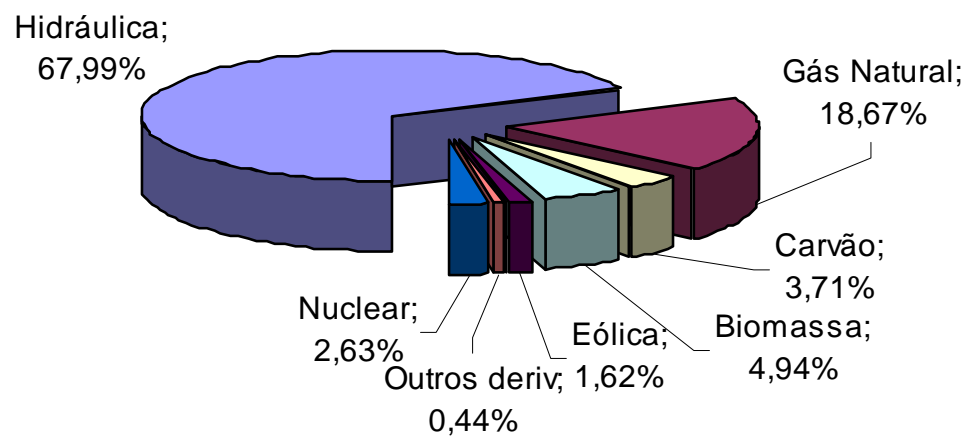

Figura 2.5. Matriz de Energia Elétrica 2023: Cenário alternativo 2 (adaptado de MME, 2006a).

Os defensores do aumento da utilização do gás natural na matriz energética do país afirmam que o gás natural é o combustível fóssil "mais limpo". Segundo Williams (2000), as usinas que utilizam gás natural não emitem dióxido de enxofre nem particulados e suas emissões de $\mathrm{NO}_{x}$ são cerca de $90 \%$ menores em relação às usinas à base de carvão, por unidade de produção de eletricidade.

Sabe-se, porém, que a geração térmica caracteriza-se por uma atividade potencialmente poluidora por causar significativos impactos ambientais, principalmente decorrentes do uso da água utilizada no sistema de resfriamento e da deterioração da qualidade do ar devido à emissão de poluentes atmosféricos, e, portanto, encontra-se 
incluída nas Resoluções CONAMA 001/86 e 237/97 como atividade passível de licenciamento ambiental.

Segundo Bajay et al. (2000) apud ANEEL (2005), embora existam tecnologias de redução da quantidade de água necessária, dependendo do volume de água captado, das perdas por evaporação e do despejo de efluentes, os impactos certamente podem ser significativos. Em termos de poluição atmosférica, destacam-se as emissões de óxidos de nitrogênio $\left(\mathrm{NO}_{\mathrm{x}}\right)$, dentre os quais o dióxido de nitrogênio $\left(\mathrm{NO}_{2}\right)$, um dos principais componentes do chamado $\mathrm{smog}^{2}$, e o óxido nitroso $\left(\mathrm{N}_{2} \mathrm{O}\right)$, um dos gases causadores do efeito estufa e que também contribui para a redução da camada de ozônio (CASA, 2001 apud ANEEL, 2005).

O Quadro 2.2 apresenta alguns dos potenciais impactos ambientais positivos $(P)$ e negativos (N) observados nas fases de planejamento (PL), implantação (I) e operação $(\mathrm{O})$ de uma usina termelétrica a gás natural, elaborada com base nos EIAs referentes aos seis processos de licenciamento ambiental analisados junto ao DAIA.

Apesar dos evidentes impactos ambientais decorrentes da geração térmica e a conseqüente necessidade de avaliação da viabilidade ambiental dos empreendimentos termelétricos, empreendedores e alguns setores governamentais (notadamente aqueles mais interessados na rápida expansão da infra-estrutura energética) contestam o licenciamento ambiental por entenderem que a agilidade na análise dos processos é aquém da desejável e isso traz conseqüências para o setor e para a sociedade de um modo geral, tais como: projetos civis de termelétricas estagnados, carência na oferta de energia elétrica principalmente em regiões afastadas aos pólos financeiros, falsas expectativas de crescimento do setor energético e conseqüentes reduções de investimentos no setor.

Gomide (2004) aponta a falta de uma maior integração entre as políticas energética e ambiental como a grande dificuldade para atender as necessidades energéticas do país de forma sustentável.

\footnotetext{
${ }^{2}$ Mistura de fumaça (contendo vários poluentes) e de nevoeiro, que, sob determinadas condições atmosféricas, se forma sobre os grandes centros urbanos e industriais (ANEEL, 2005).
} 


\begin{tabular}{|c|c|c|c|}
\hline Aspecto & Impacto & Fase & Natureza \\
\hline Emissões & Alteração da qualidade do ar & $\mathrm{O}$ & $\mathrm{N}$ \\
\hline Gasosas & Alteração das condições climáticas locais & $\mathrm{O}$ & $\mathrm{N}$ \\
\hline \multirow{2}{*}{$\begin{array}{l}\text { Geração de } \\
\text { Ruídos }\end{array}$} & \multirow{2}{*}{$\begin{array}{l}\text { Interferência sobre o cotidiano da população } \\
\text { Surgimento de problemas auditivos } \\
\text { trabalhadores }\end{array}$} & $\mathrm{I}, \mathrm{O}$ & $\mathrm{N}$ \\
\hline & & $\mathrm{I}, \mathrm{O}$ & $\mathrm{N}$ \\
\hline \multirow{4}{*}{$\begin{array}{l}\text { Demanda pelos } \\
\text { recursos } \\
\text { hídricos }\end{array}$} & $\begin{array}{l}\text { Alteração nos níveis de vazão e disponibilidade } \\
\text { hídrica }\end{array}$ & $\mathrm{O}$ & $\mathrm{N}$ \\
\hline & \multirow{2}{*}{$\begin{array}{l}\text { Comprometimento de demais usos a jusante } \\
\text { Alteração da qualidade da água }\end{array}$} & O & $\mathrm{N}$ \\
\hline & & $\mathrm{I}, \mathrm{O}$ & N \\
\hline & $\begin{array}{l}\text { Alteração na Dinâmica dos Ecossistemas } \\
\text { Aquáticos }\end{array}$ & 0 & $\mathrm{~N}$ \\
\hline \multirow{3}{*}{$\begin{array}{l}\text { Limpeza do } \\
\text { terreno, } \\
\text { movimentação } \\
\text { de solo e rocha }\end{array}$} & \multirow{3}{*}{$\begin{array}{l}\text { Instalação de Processos Erosivos e } \\
\text { Assoreamento } \\
\text { Aumento na taxa de escoamento superficial } \\
\text { Aumento de partículas de poeira no ar }\end{array}$} & I & $\mathrm{N}$ \\
\hline & & 1 & $\mathrm{~N}$ \\
\hline & & i & $\mathrm{N}$ \\
\hline $\begin{array}{l}\text { Geração de } \\
\text { Material de } \\
\text { Bota-Fora }\end{array}$ & $\begin{array}{l}\text { Possibilidade de Contaminação de Solo e } \\
\text { Subsolo por compostos químicos }\end{array}$ & I & $\mathrm{N}$ \\
\hline \multirow{2}{*}{$\begin{array}{l}\text { Supressão de } \\
\text { Vegetação }\end{array}$} & $\begin{array}{l}\text { Perda de variabilidade genética e de espécies } \\
\text { endêmicas }\end{array}$ & $\mathrm{I}, \mathrm{O}$ & $\mathrm{N}$ \\
\hline & Simplificação da Paisagem & $\mathrm{O}$ & $\mathrm{N}$ \\
\hline \multirow{11}{*}{$\begin{array}{l}\text { Demanda por } \\
\text { mão-de-obra }\end{array}$} & \multirow{11}{*}{$\begin{array}{l}\text { Geração de Expectativas } \\
\text { Aumento da Oferta de Postos de Trabalho } \\
\text { Ampliação da Atração Demográfica } \\
\text { Aumento de Renda } \\
\text { Incremento das Atividades Terciárias } \\
\text { Proliferação de Atividades Informais } \\
\text { Ampliação da Demanda por Serviços Públicos } \\
\text { Surgimento de Favelas nas imediações do } \\
\text { Canteiro de Obras } \\
\text { Ampliação da Receita Tributária } \\
\text { Dinamização da economia do município afetado } \\
\text { Aumento do Tráfego }\end{array}$} & $\mathrm{PL}, \mathrm{I}$ & $\mathrm{N}$ \\
\hline & & 1,0 & $P$ \\
\hline & & $\mathrm{I}, \mathrm{O}$ & $\mathrm{N}$ \\
\hline & & 1,0 & $P$ \\
\hline & & 1,0 & $P$ \\
\hline & & 1,0 & $\mathrm{~N}$ \\
\hline & & $\mathrm{I}, \mathrm{O}$ & $\mathrm{N}$ \\
\hline & & $\mathrm{I}, \mathrm{O}$ & $\mathrm{N}$ \\
\hline & & $\mathrm{I}, \mathrm{O}$ & $P$ \\
\hline & & 1,0 & $P$ \\
\hline & & 1 & $\mathrm{~N}$ \\
\hline $\begin{array}{l}\text { Desmobilização } \\
\text { da mão-de- } \\
\text { obra }\end{array}$ & Redução da Oferta de Empregos & $\mathrm{O}$ & $\mathrm{N}$ \\
\hline
\end{tabular}

De acordo com a pesquisa Sondagem Especial sobre o Meio Ambiente, realizada pela Confederação Nacional da Indústria (CNI, 2007a), das 1491 empresas pesquisadas, 66,9\% consideram a demora na análise de processos o principal entrave quando o assunto é licenciamento ambiental. Os custos elevados para cumprir as exigências foram citados por 52\%, enquanto que 42,6\% apontaram a dificuldade em identificar critérios (Figura 2.6). 


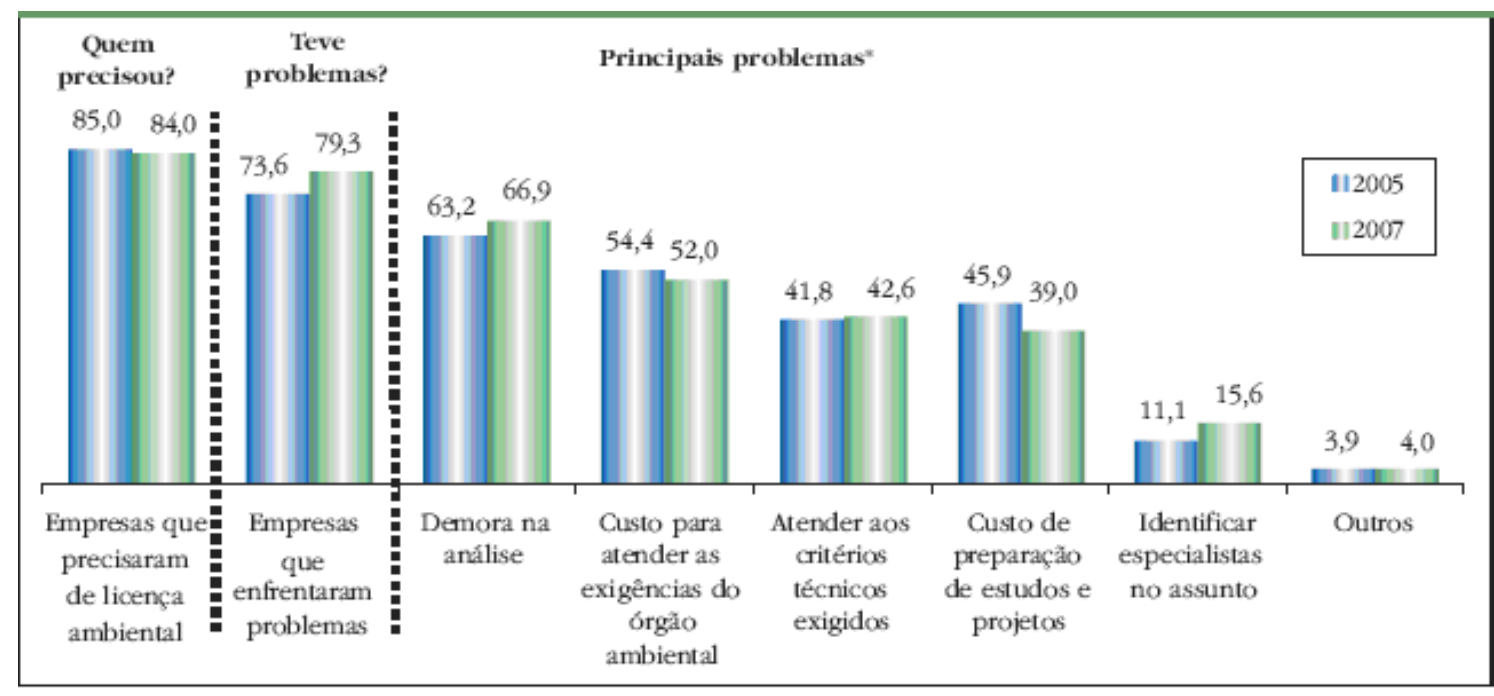

Figura 2.6. Principais problemas enfrentados pela indústria no processo de Licenciamento (\%) (Fonte: CNI, 2007a)

Segundo CNI (2007b), "[...] é fundamental que o processo de licenciamento ambiental ganhe em rapidez, transparência e objetividade, de forma a promover o crescimento econômico em conjunto com a conservação do meio ambiente".

Apesar das críticas sobre a morosidade dos processos de licenciamento em geral, e do setor energético em particular, não há estudos que apontem com segurança a existência de relação entre fatores ligados ao procedimento de licenciamento ambiental e o tempo total de tramitação dos processos. A identificação de interferências sobre o tempo de tramitação pode fornecer subsídios e aprimorar a eficiência do procedimento de licenciamento ambiental, indispensável para a conciliação entre o desenvolvimento econômico e a qualidade ambiental desejada pela sociedade. 


\section{OBJETIVO}

Este trabalho tem como objetivo geral: "Analisar a interferência de alguns fatores, apontados como responsáveis pela demora no licenciamento ambiental, sobre os tempos de tramitação de processos de licenciamento prévio de empreendimentos termelétricos propostos no Estado de São Paulo".

Os objetivos específicos são:

1) Identificar os fatores ligados aos procedimentos de licenciamento ambiental com potencial de interferir nos tempos de tramitação dos processos;

2) Analisar os processos de licenciamento ambiental de empreendimentos termelétricos que tramitaram no âmbito do DAIA, entre os anos de 1998 e 2007 frente aos fatores identificados;

3) Verificar, com base nas análises dos processos frente aos fatores identificados, a existência de relação entre tais fatores e o tempo total de tramitação dos processos. 


\section{MATERIAIS E MÉTODOS}

\subsection{Método Científico}

Lakatos e Marconi (1987) definem a pesquisa científica como "um procedimento formal que requer a adoção de um tratamento técnico ou científico, e se constitui no caminho para se conhecer a realidade ou para descobrir verdades parciais". Neste sentido, para a realização de uma pesquisa há a necessidade de se adotar um método científico, e a escolha por um ou outro depende de fatores como: natureza do objeto que se pretende pesquisar, recursos materiais disponíveis, nível de abrangência do estudo e, sobretudo, da inspiração filosófica do pesquisador (CCEM, 2008).

Considerando que os processos de licenciamento ambiental podem ser considerados documentos cientificamente autênticos e que é garantida a legitimidade dos dados por ser uma fonte de dados primários representados por meio de documentos públicos e oficiais (VERGARA, 2007), sendo ofícios, pareceres, memorandos, cartas, relatórios, dentre outros, a metodologia utilizada nesta pesquisa caracteriza-se pela Análise Documental de processos de licenciamento ambiental de empreendimentos termelétricos, considerada por Godoy (1995) uma das técnicas de maior confiabilidade.

Tais processos foram iniciados devido à solicitação de licença ambiental prévia a empreendimentos termelétricos a gás natural, com potência instalada superior a $10 \mathrm{MW}$ e propostos no estado de São Paulo, processos estes que tramitaram no âmbito do DAIA entre os anos de 1998 e 2007.

Portanto, por meio da análise documental de processos de licenciamento ambiental, os procedimentos adotados encontram-se descritos a seguir.

\subsection{Descrição dos procedimentos adotados}

Inicialmente foi adotado como indicador de eficiência dos processos de licenciamento ambiental o "tempo total de tramitação do processo", uma vez que é normalmente apontado por diversos agentes econômicos (CNI, 2007a; CNI, 2007b) e, particularmente, por aqueles ligados ao setor elétrico como o principal gargalo quando o assunto é licenciamento ambiental. 
Para a identificação dos fatores ligados aos procedimentos de licenciamento ambiental com potencial de interferir nos tempos de tramitação dos processos foi realizada revisão bibliográfica (livros e artigos científicos) e documental (processos de licenciamento ambiental). Na revisão foram identificados diversos fatores com potencial para interferir na agilidade do andamento dos processos, que vão desde o número de funcionários do órgão ambiental envolvidos no licenciamento até a capacidade de mobilização da sociedade na região do empreendimento a ser licenciado, passando por aspectos como a qualidade técnica dos estudos apresentados. Nesse sentido, houve necessidade de priorização dos fatores a serem considerados. Assim, foram feitas consultas aos profissionais ligados à área de Instrumentos de Gestão Ambiental - especialmente aos técnicos do DAIA diretamente envolvidos com o licenciamento ambiental dos empreendimentos termelétricos - que auxiliaram na seleção dos fatores a serem analisados. O principal critério utilizado para a seleção foi a possibilidade de identificar/quantificar o fator interveniente apenas com a análise do processo, ou seja, sem a necessidade de consultar outras fontes.

Além dos fatores quantitativos, outros fatores (fatores qualitativos) que pudessem interferir nos procedimentos, identificados na leitura dos processos, também foram considerados nas análises. Exemplos de fatores qualitativos intervenientes são: interferência do empreendimento em Unidades de Conservação e seu entorno, adequação do empreendimento às normas de uso e ocupação do solo municipal, proximidade com áreas urbanas e disponibilidade hídrica.

Uma vez identificados tais fatores, tanto os quantitativos quanto os qualitativos, foi realizada a revisão documental dos processos de licenciamento ambiental que tramitaram no DAIA/SMA entre 1998 e 2007, e que objetivavam a implantação de usinas termelétricas a gás natural com potência instalada superior a $10 \mathrm{MW}$. Os processos foram consultados na íntegra diretamente no órgão ambiental e deles foram obtidos dados quantitativos e informações qualitativas que permitiriam a verificação da medida de interferência dos fatores selecionados sobre o tempo total de tramitação dos processos.

Os dados e informações foram coletados por meio de todos os documentos gerados e constantes nos processos, a saber, ofícios, memorandos, cartas, faxes, pareceres, licenças, deliberações, atas de reunião, entre outros, incluindo-se os EIAs apresentados. 
É importante destacar que apesar de terem sido coletadas informações gerais de todos os processos encontrados que tramitaram entre 1998 e 2007 no estado de São Paulo, para que fosse possível uma análise comparativa entre eles, a fim de se alcançar o objetivo de uma forma coerente, havia a necessidade de que os processos apresentassem certa similaridade de tramitação. Portanto, foi adotado um recorte considerando como objeto desta pesquisa somente os processos que resultaram na emissão da licença ambiental prévia, ou seja, os processos que iniciaram-se com a apresentação do RAP até a concessão da LP. Neste sentido, os processos analisados representam a totalidade dos casos, segundo o recorte adotado. 


\section{RESULTADOS E DISCUSSÃO}

\subsection{Identificação dos fatores que influenciam no tempo total de tramitação do processo de Licenciamento Ambiental}

Enquanto a eficácia remete-nos ao resultado a que o processo de licenciamento ambiental deve chegar, ou seja, a tomada de decisão e a concessão ou não da licença ambiental, a eficiência reflete o desempenho interno do processo de licenciamento ambiental, e, portanto, pode ser entendida pela relação entre os resultados alcançados e os recursos utilizados durante o processo.

Neste sentido a eficácia enfatiza o alcance dos resultados, por meio do atendimento dos objetivos, enquanto que a eficiência valoriza os meios a que fizeram chegar ao resultado, procura a solução de problemas internos ao processo e o cumprimento de tarefas.

Portanto, inerentes ao processo de licenciamento ambiental, independentemente da tipologia do empreendimento, os indicadores de eficiência podem medir ou quantificar características comuns a todo procedimento, permitindo assim que seja possível uma análise comparativa entre os processos. Para a determinação desses indicadores foi realizado levantamento por meio de estudo bibliográfico e reuniões com profissionais ligados à área de Gestão Ambiental, em especial, com os profissionais diretamente envolvidos no processo de licenciamento ambiental.

Foi selecionado como indicador de eficiência do processo de licenciamento ambiental o tempo total de tramitação do processo, desde a solicitação até a obtenção da licença prévia. Por meio do estudo dos procedimentos de licenciamento foram identificados os fatores inerentes ao procedimento e que possam interferir neste indicador, são eles:

- Número de solicitações de informações complementares feitas pelos órgãos ambientais ao empreendedor;

- Número de impactos ambientais identificados no EIA/RIMA apresentado;

- Número de condicionantes exigidas pelos órgãos licenciadores por meio da Licença Ambiental Prévia expedida. 
O "tempo total de tramitação do processo para obtenção da LP" é o tempo (em dias) desde a solicitação de licença prévia, por parte do empreendedor, até a concessão da mesma pelo órgão licenciador. São considerados, portanto, o tempo de análise realizada pelos órgãos envolvidos (DAIA, Consema, Cetesb, DEPRN, Comitê de Bacias Hidrográficas, IBAMA etc), o tempo de elaboração de estudos exigidos ao empreendedor após o pedido de $\mathrm{LP}^{3}$, o tempo de resposta do empreendedor às solicitações complementares feitas pelos órgãos ambientais e o tempo que eventualmente o processo tenha ficado parado em função, por exemplo, de decisões judiciais.

É importante salientar que, o tempo total de tramitação não se refere ao somatório do tempo em cada agente envolvido no processo, uma vez que a análise pode estar sendo feita naquele momento por um ou mais agentes, ou ainda, que enquanto um agente aguarda resposta do empreendedor a alguma solicitação, outro agente pode estar analisando o caso, pois entende que, para sua manifestação, as informações apresentadas são satisfatórias. Portanto, durante a tramitação do processo existe uma sobreposição de tempos.

O "número de solicitações de informações complementares" compreende o número de vezes em que foram feitas solicitações ao empreendedor, tanto pelo DAIA quanto pelos demais agentes envolvidos no processo. A utilização deste fator baseiase no pressuposto de que quanto maior o número de solicitações de informações feitas ao empreendedor, maior tenderá a ser o tempo total de tramitação, já que o empreendedor demandará algum tempo para fornecer uma resposta e, enquanto isso, a análise do processo fica suspensa ${ }^{4}$. Este aspecto permite inferir também se o estudo entregue apresenta deficiências, o que motiva o órgão licenciador ou os demais agentes envolvidos a solicitar complementações.

${ }^{3}$ No caso de empreendimentos que dão entrada ao pedido de LP com apresentação de RAP, o tempo para a elaboração deste estudo não é considerado, pois não é possível, analisando os processos, determinar quando teve início a elaboração do RAP. Já os tempos para a elaboração do Plano de Trabalho e do EIA/RIMA são computados para fins de cálculo do tempo total de tramitação do processo.

${ }^{4} \mathrm{Na}$ verdade, enquanto o empreendedor providencia a resposta, os agentes evolvidos no processo podem estar analisando o processo, mas o prazo regulamentar para análise fica suspenso. 
O fator "número de impactos ambientais identificados no EIA" foi analisado para dar a idéia da fragilidade do meio frente ao empreendimento. Partindo da premissa de que, se o EIA foi elaborado de forma criteriosa, quanto maior o número de impactos identificados, tanto maior deve ser a fragilidade ambiental do local onde 0 empreendimento está sendo proposto e, ao contrário, quanto menor o número de impactos, maior a adequação do empreendimento ao local. Entretanto, a identificação de um número reduzido de impactos também pode indicar deficiências de elaboração do EIA/RIMA apresentado. Sendo assim, este fator precisa ser necessariamente observado em conjunto com o número de condicionantes constante na licença.

O elevado "número de condicionantes exigidas por meio da Licença Prévia expedida" associado a um baixo número de impactos identificados permite supor que os impactos foram subestimados, ou seja, o EIA foi mal elaborado e apresenta deficiências como as apontadas por MPF (2004) e representadas no Quadro 2.2. Por sua vez, o baixo número de condicionantes associado a um alto número de impactos identificados no EIA pode indicar que o diagnóstico da área de influência do empreendimento foi criterioso, a previsão dos impactos foi detalhada e as medidas mitigadoras propostas são adequadas e suficientes para tornar compatível o empreendimento ao local proposto. A terceira situação possível é a combinação de um baixo número de impactos identificados com um baixo número de condicionantes, que indica que o local proposto para o empreendimento apresenta elevada capacidade de suporte para aquela tipologia, cabendo ao órgão licenciador exigir apenas condicionantes pontuais. Esta situação, ao contrário, também pode indicar que o EIA foi mal elaborado (poucos impactos identificados) e o órgão ambiental falhou ao analisar o estudo ou foi omisso ao não apontar as falhas do EIA, o que representa uma situação grave. Por fim, a quarta combinação possível, é a identificação de um elevado número de impactos associada à exigência de um grande número de condicionantes. Esta situação aponta no sentido de que o local proposto para o empreendimento é frágil do ponto de vista ambiental, a identificação dos impactos foi realizada de forma criteriosa no EIA, mas as medidas mitigadoras propostas são insuficientes (EIA deficiente), o que obriga ao órgão ambiental solicitar muitas condicionantes. Um quadro resumo com as combinações entre os dois fatores é apresentado no Quadro 5.1. 


\begin{tabular}{|c|c|c|c|}
\hline \multicolumn{4}{|c|}{ Número de condicionantes exigidos pelo órgão licenciador na LP } \\
\hline & & Baixo & Alto \\
\hline 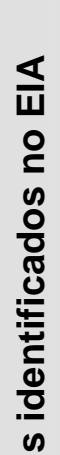 & 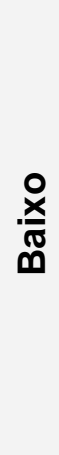 & $\begin{array}{l}\text { Local com elevada capacidade de } \\
\text { suporte para receber o } \\
\text { empreendimento e estudo bem } \\
\text { elaborado (situação mais desejável) } \\
\text { ou estudo mal elaborado e falha na } \\
\text { análise ou omissão do órgão } \\
\text { ambiental (situação menos desejável). }\end{array}$ & $\begin{array}{l}\text { Local com baixa capacidade de } \\
\text { suporte para receber o } \\
\text { empreendimento e estudo mal } \\
\text { elaborado. }\end{array}$ \\
\hline 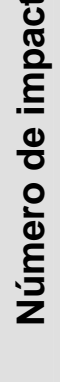 & 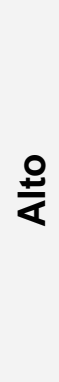 & $\begin{array}{l}\text { Local com baixa capacidade de } \\
\text { suporte para receber o } \\
\text { empreendimento e estudo bem } \\
\text { elaborado tanto na identificação de } \\
\text { impactos quanto na proposição de } \\
\text { medidas mitigadoras. }\end{array}$ & $\begin{array}{l}\text { Local com baixa capacidade de } \\
\text { suporte para receber o } \\
\text { empreendimento e estudo bem } \\
\text { elaborado na identificação dos } \\
\text { impactos, mas falho na proposição } \\
\text { de medidas mitigadoras. }\end{array}$ \\
\hline
\end{tabular}

Quadro 5.1. Possíveis combinações entre o número de impactos identificados no EIA e o número de condicionantes exigidas pelos órgãos licenciadores.

É importante comentar que um elevado número de condicionantes constantes na LP expedida associado a um baixo número de impactos ambientais identificados no EIA apresentado pode também indicar uma análise excessivamente criteriosa por parte dos técnicos responsáveis, mas esta hipótese não é considerada neste estudo.

A caracterização e análise dos processos de licenciamento ambiental de empreendimentos termelétricos que tramitaram no âmbito do DAIA, por meio da quantificação destes frente aos fatores identificados e descritos acima permite a comparação dos processos entre si e o apontamento quanto à interferência destes fatores sobre o tempo total de tramitação dos processos, relacionando, assim, com a maior ou menor eficiência dos procedimentos. 


\subsection{Caracterização dos empreendimentos e análise dos processos de licenciamento ambiental}

Conforme descrito no item 4.2 deste trabalho, inicialmente, por meio de pesquisa realizada no DAIA, foram identificados 18 processos de solicitação de licenciamento ambiental referente à instalação de 15 usinas termelétricas a gás natural, com potência instalada superior a $10 \mathrm{MW}$ e, portanto, licenciadas por meio de apresentação de EIA/RIMA, a serem instaladas no estado de São Paulo.

Porém, a fim de tornar possível a análise de cada processo frente aos fatores selecionados e efetuar uma comparação entre eles, neste trabalho foram estudados somente os processos de empreendimento que obtiveram a referida licença prévia.

O Quadro 5.2 lista os processos de licenciamento ambiental que tramitaram no DAIA no período compreendido entre 1998 e 2007 mas que não são objeto deste trabalho pois não resultaram na emissão de LP. No Quadro 5.3 são apresentados os processos que foram analisados no presente estudo.

É importante mencionar que os processos analisados neste trabalho tramitaram quando, no estado de São Paulo, o procedimento de licenciamento ambiental era normatizado pela Resolução SMA $n^{\circ} 42$ de 1.994, que instituiu o RAP como instrumento preliminar ao EIA/RIMA. De acordo com tal Resolução, o RAP era solicitado a fim de esclarecer, de forma rápida e sucinta, os impactos ambientais previstos para implantação de um dado empreendimento e apontar ao órgão competente a necessidade ou não de exigência de apresentação de EIA/RIMA. Esta norma, no entanto, causou bastante polêmica, uma vez que para o licenciamento de empreendimentos como os de geração de energia com capacidade superior a $10 \mathrm{MW}$ era previsto, pela Resolução CONAMA 001/86, a necessidade de apresentação de EIA/RIMA. Em que pese a grande discussão gerada na época, os procedimentos no estado de São Paulo seguiram a regra paulista em detrimento da regra nacional, ou seja, todos os pedidos de LP foram protocolados com apresentação de RAP, cabendo ao DAIA a exigência ou dispensa de apresentação do EIA/RIMA após a análise do RAP. 


\begin{tabular}{|c|c|c|c|}
\hline $\begin{array}{l}\text { Processo } \\
\text { SMA }\end{array}$ & UTE & Município & Observações \\
\hline $13.540 / 2002$ & Ribeirão Preto & $\begin{array}{l}\text { Ribeirão } \\
\text { Preto }\end{array}$ & EIA/RIMA não protocolados \\
\hline $\begin{array}{l}13.791 / 2001 \\
13.531 / 2002\end{array}$ & $\begin{array}{l}\text { Ribeirão do } \\
\text { Moinho }\end{array}$ & Andradina & $\begin{array}{l}\text { Análise RAP concluído - Exigido } \\
\text { EIA/RIMA } \\
\text { Complementações ao EIA não } \\
\text { atendidas }\end{array}$ \\
\hline $13.758 / 2001$ & Sorocaba & Sorocaba & EIA/RIMA não protocolados \\
\hline $13.730 / 2001$ & Anhanguera & Limeira & $\begin{array}{l}\text { Complementações ao EIA não } \\
\text { atendidas }\end{array}$ \\
\hline $13.588 / 2001$ & Bariri & Bariri & $\begin{array}{l}\text { Complementações ao EIA não } \\
\text { atendidas }\end{array}$ \\
\hline $13.549 / 2001$ & Paulínia II & Mogi Mirim & $\begin{array}{l}\text { EIA/RIMA não protocolados e } \\
\text { Auto de Infração }\end{array}$ \\
\hline $13.584 / 2002$ & Mogi Mirim & Mogi Guaçu & $\begin{array}{l}\text { EIA/RIMA não protocolados e } \\
\text { Auto de Infração }\end{array}$ \\
\hline $\begin{array}{l}13.740 / 2006 \\
13.724 / 2007\end{array}$ & $\begin{array}{l}\text { Paulínia II e Mogi } \\
\text { Mirim }\end{array}$ & $\begin{array}{l}\text { Mogi Mirim e } \\
\text { Mogi Guaçu }\end{array}$ & $\begin{array}{l}\text { Análise do Plano de Trabalho } \\
\text { concluído - Emitido Termo de } \\
\text { Referência } \\
\text { Pedido de LP indeferido, EIA } \\
\text { reprovado }\end{array}$ \\
\hline $13.757 / 1998$ & Bom Jardim & Jundiaí & $\begin{array}{l}\text { Fase Plano de Trabalho - } \\
\text { Arquivado à pedido do } \\
\text { interessado }\end{array}$ \\
\hline $13.626 / 1998$ & Planalto Paulista & Paulínia & $\begin{array}{l}\text { Solicitação de reelaboração de } \\
\text { EIA/RIMA, não protocolados }\end{array}$ \\
\hline
\end{tabular}

\begin{tabular}{ccccc}
\hline $\begin{array}{c}\text { Processo } \\
\text { SMA }\end{array}$ & Município & UTE & $\begin{array}{c}\text { Potência } \\
\text { MW }\end{array}$ & LP \\
\hline $13.698 / 1998$ & Cubatão & $\begin{array}{c}\text { Central de Cogeração } \\
\text { da Baixada Santista }\end{array}$ & 950 & $381 / 01$ \\
\hline $13.696 / 1999$ & Santa Branca & Santa Branca & 1.067 & $\begin{array}{c}470 / 01 \\
\text { (cancelada) }\end{array}$ \\
\hline $13.629 / 2000$ & Pederneiras & Duke Energy I & 500 & $457 / 01$ \\
\hline $13.545 / 2000$ & Americana & Carioba II & 1.200 & $492 / 02$ \\
\hline $\begin{array}{c}13.506 / 2001 \\
13.734 / 2003\end{array}$ & Araraquara & Araraquara & 512 & $807 / 05$ \\
\hline $\begin{array}{l}\text { Quadro 5.3. Processos de licenciamento ambiental que tramitaram no DAIA no período } \\
\text { compreendido entre 1998 e 2007 e resultaram na emissão de LP. }\end{array}$ &
\end{tabular}

Sabe-se, atualmente, que a Resolução 001/86 quando lista em seu Art. $2^{\circ}$ as atividades passíveis de licenciamento ambiental por meio de EIA/RIMA tem apenas caráter exemplificativo e, portanto, o órgão ambiental estadual possui autonomia, após 
a devida análise da tipologia e porte do empreendimento e localização proposta, indicar a necessidade de apresentação de EIA/RIMA ou adotar um procedimento simplificado, com a apresentação de RAP por parte do empreendedor, onde as exigências legais de audiência pública, em caso de solicitação (Resolução CONAMA 001/86 e Resolução CONAMA 009/87), e compensação ambiental (Lei 9.985/2000) não se aplicam.

A seguir, os empreendimentos citados no Quadro 5.3 são caracterizados de forma mais detalhada e seus respectivos processos de licenciamento ambiental que tramitaram no âmbito do DAIA são analisados frente aos fatores selecionados. Também é apresentada uma representação gráfica de todo o trâmite dos processos e uma análise de fatores qualitativos que podem ter interferido no decorrer de cada processo. 


\subsubsection{UTE Central de Cogeração da Baixada Santista - CCBS}

Como este estudo analisa o processo de licenciamento ambiental prévio, as informações contidas no Quadro 5.4 são as características do empreendimento de acordo com o projeto inicial, ou seja, de quando obteve a LP em 2001. O projeto da UTE CCBS foi modificado, e, atualmente, o empreendimento caracteriza-se por potência instalada e geração de vapor inferiores aos de quando foi licenciada.

\begin{tabular}{|c|c|}
\hline Empreendimento & $\begin{array}{l}\text { Central de Cogeração da Baixada Santista } \\
\text { (CCBS) }\end{array}$ \\
\hline Número do processo no DAIA & SMA 13.698/1998 (SMA, 1998) \\
\hline Município & Cubatão \\
\hline Empreendedor & $\begin{array}{l}\text { Baixada Santista Energia Ltda, consórcio } \\
\text { firmado entre Marubeni Corporation (trading } \\
\text { japonesa) e Petrobrás. }\end{array}$ \\
\hline Local de implantação & 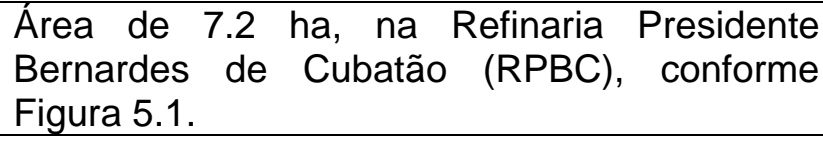 \\
\hline Coordenadas & $23^{\circ} 51^{\prime} 53.80 " \mathrm{~S} ; 46^{\circ} 25^{\prime} 29.45^{\prime \prime} \mathrm{W}$ \\
\hline Potência Instalada & $\begin{array}{l}950 \mathrm{MW} \text { (95 MW para atender a demanda da } \\
\text { RPBC e o restante para comercialização) }\end{array}$ \\
\hline Combustível & 4 milhões $\mathrm{m}^{3} /$ dia de gás natural \\
\hline Investimento & US\$ 650 milhões \\
\hline Rio para captação & Cubatão \\
\hline $\begin{array}{l}\text { Intervenção em Unidade de } \\
\text { Conservação }\end{array}$ & Parque Estadual Serra do Mar \\
\hline Restrições Ambientais destacadas & Região saturada por poluentes atmosféricos. \\
\hline Previsão para ser instalada & 2001 \\
\hline Licença Ambiental Prévia & LP no 00381 de $01 / 02 / 2001$ \\
\hline Observações & $\begin{array}{l}\text { Inscrita no PPT (Usina de cogeração a gás } \\
\text { natural, conforme Portaria 43/2000). }\end{array}$ \\
\hline
\end{tabular}

Quadro 5.4. Principais características da UTE CCBS.

Após a aprovação pelo Consema, que se deu sob grande manifestação de ambientalistas e do Ministério Público, e conseqüente concessão da LP, tramitou na Câmara dos Vereadores de Cubatão um projeto de emenda à Lei Orgânica municipal que proibiria a instalação de termelétricas na região. No entanto, foi uma liminar, concedida em 2001 à Ação Civil Pública da Promotoria de Justiça de Meio Ambiente de Cubatão, que impediu a instalação da usina, programada para entrar em operação no mesmo ano. A promotoria alegou, na ocasião, que a instalação do empreendimento 
no sítio proposto seria ilegal, em função da saturação por poluentes já verificada no local.

Segundo Cuoco (2001), esta foi a primeira liminar obtida contra o programa emergencial do governo que pretendia construir 49 usinas em todo o país, dentre as quais 17 movidas a gás natural no estado de São Paulo.

Em 2005 a Petrobrás anunciou a compra da UTE CCBS, e esta, que recebeu o nome de Usina Termelétrica Euzébio Rocha, encontra-se em construção desde fevereiro de 2007, com previsão para entrar em operação a partir do segundo semestre de 2008. As características do projeto foram modificadas e atualmente a capacidade instalada é para a geração de $208 \mathrm{MW}$ de energia (47MW para atender a demanda da RPBC e comercialização da energia excedente) e produção de 415 t/h de vapor.

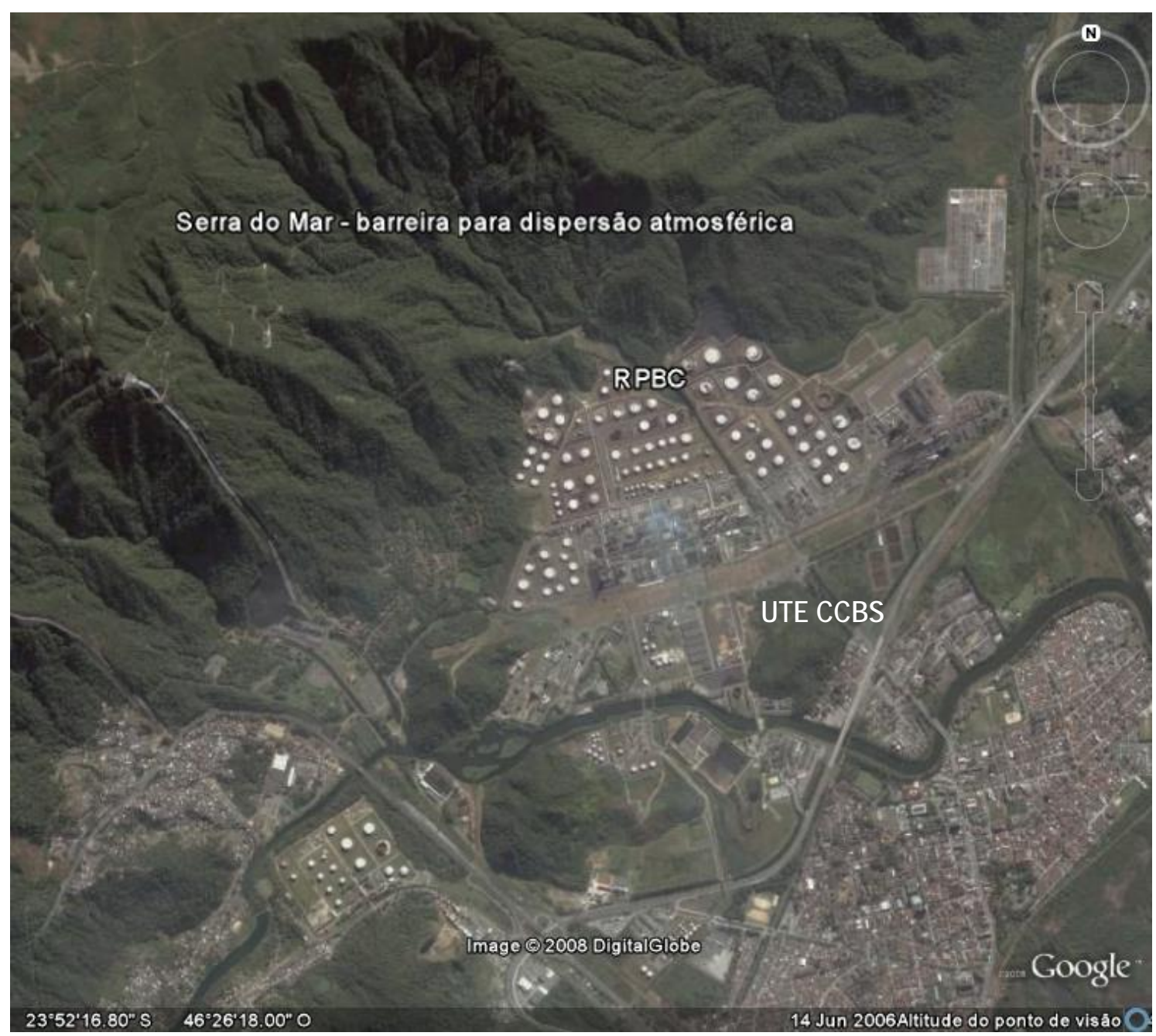

Figura 5.1. Localização proposta para implantação da UTE CCBS (extraído de Google Earth). 
A Tabela 5.1 representa a caracterização do processo de licenciamento ambiental da UTE CCBS junto ao DAIA (Processo SMA 13.698/1998), frente aos fatores selecionados, desde a apresentação do RAP até a concessão da LP.

Tabela 5.1. Caracterização do processo SMA 13.698/1998 frente aos fatores selecionados.

\begin{tabular}{|l|c|}
\hline \multicolumn{1}{|c|}{ Fatores selecionados } & Quantificação \\
\hline Número de solicitações de informações complementares & 5 \\
\hline Número de impactos ambientais identificados no EIA/RIMA & 21 \\
\hline Número de condicionantes exigidas por meio da LP expedida & 16 \\
\hline
\end{tabular}

Conforme Tabela 5.1, Tabela 5.2 e Figura 5.2, do tempo total de tramitação do processo de licenciamento ambiental da UTE CCBS, ou seja, desde a apresentação do RAP até a concessão da LP, 32\% deste ficou sob responsabilidade do empreendedor, quer tenha sido para a elaboração do Plano de Trabalho e do EIA/RIMA ou ainda para o atendimento das 5 vezes em que foram solicitadas informações complementares.

Apesar de ainda não determinada a obrigatoriedade da autorização do órgão gestor da Unidade de Conservação a ser afetada, conforme Lei Federal no 9.985/2000 (BRASIL, 2000b), neste processo foi solicitada a manifestação do Instituto Florestal devido a alternativa locacional proposta estar próxima ao Parque Estadual da Serra do Mar, núcleo Pilões, criado pelo Decreto 10.251 de 1977.

Do tempo total em cada agente do processo (Figura 5.3) é necessário destacar que existe uma sobreposição de atuação dos agentes, o que pode ser claramente observado na Figura 5.4 que representa toda a tramitação do processo. Portanto, somando-se o tempo em cada agente o resultado é superior ao tempo total de tramitação do processo.

Observa-se que o tempo total de tramitação do processo sob responsabilidade do IF foi superior ao tempo sob responsabilidade do DAIA, uma vez que para continuidade da análise de viabilidade ambiental do empreendimento por parte do DAIA foram solicitadas 5 vezes informações complementares e, enquanto eram providenciadas as informações, o processo ficou sob responsabilidade do empreendedor. 
Tabela 5.2. Análise dos tempos de tramitação do processo SMA 13.698/1998.

\begin{tabular}{|l|c|}
\hline \multicolumn{1}{|c|}{ Tempos de tramitação } & Quantificação \\
\hline Tempo total de tramitação do processo até a obtenção da LP & 877 dias \\
\hline Tempo total de tramitação que depende do empreendedor & 281 dias \\
\hline Tempo total de tramitação que independe de ação do empreendedor & 596 dias \\
\hline
\end{tabular}

\section{Tempo total de tramitação do processo}

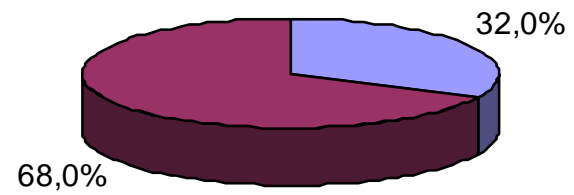

$\square$ Depende do Empreendedor $\square$ Não depende do empreendedor

Figura 5.2. Tempo total de tramitação do processo SMA 13.698/1998.

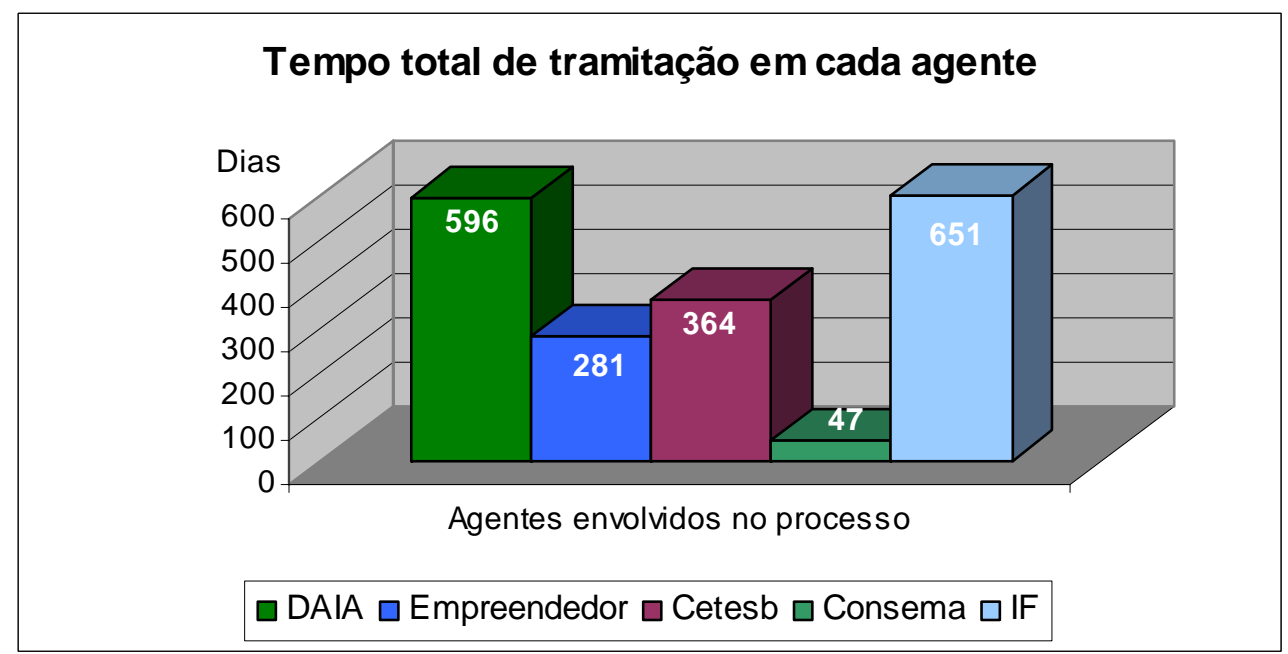

Figura 5.3. Tempo total de tramitação em cada agente envolvido no processo SMA 13.698/1998.

A Figura 5.4 representa todo o trâmite do processo e, por meio desta, pode ser visualizada a atuação dos diferentes agentes envolvidos e o tempo que cada agente foi demandado no processo de licenciamento ambiental da UTE CCBS. As 
intervenções do Ministério Público observadas foram apenas no sentido de solicitação de informações quanto ao andamento do processo. 


\begin{tabular}{|c|c|c|c|c|c|c|c|c|c|c|c|c|c|c|c|c|c|c|c|c|c|c|c|c|c|c|c|c|c|}
\hline \multirow[b]{2}{*}{ 13.698/1998 } & \multirow[t]{2}{*}{ RAP } & \multicolumn{6}{|c|}{ Plano de Trabalho } & \multicolumn{22}{|c|}{ EIA/RIMA } \\
\hline & & \multicolumn{3}{|c|}{1998} & \multicolumn{11}{|c|}{1999} & \multicolumn{12}{|c|}{2000} & \multicolumn{2}{|c|}{2001} \\
\hline IF & & & & & & & & & & & & & & & & & & & 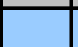 & & & 1 & . & . & 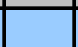 & & & & \\
\hline Cetesb & & & & & & & & & & & & & & & & & & & & & $T$ & & & & & & & & \\
\hline Consema & & & & & & & & & & & & & & & & & & & & & & & & & & & & & \\
\hline DAIA & & & & & & & & & & & & & & & & & & & & & 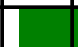 & & & & & & 1 & & \\
\hline Empreendedor & & & & & & & & & & & & & & & & & & & & & & & & & & & & & \\
\hline
\end{tabular}

Figura 5.4. Representação da tramitação do processo de licenciamento ambiental da UTE CCBS (SMA 13.698/1998). 


\section{Fatores qualitativos que podem ter interferido no tempo de tramitação do processo:}

Observa-se neste processo que, dado o contexto histórico de Cubatão de acentuado uso industrial e alto grau de poluição atmosférica, sendo esta situação agravada pela configuração topográfica da região, a questão mais crítica levantada durante o processo foi quanto à dispersão atmosférica dos poluentes resultantes do processo operacional da usina, reconhecidamente abordada pelo próprio estudo apresentado:

Ao longo do Vale do Mogi, em área de transição da Serra do Mar para a baixada litorânea, a circulação atmosférica encontra no relevo serrano uma barreira, [...]. Alternando-se, em melhor condição durante o dia e piores efeitos durante a noite, o núcleo do município de Cubatão encontra-se fora da direção predominante dos ventos [...] (SMA, 1998).

Além dos evidentes impactos sobre a saúde pública do município, a instalação da usina em Cubatão e a emissão de mais poluentes na região, já tida na época como saturada por ozônio e outros elementos, poderia acarretar em significativos impactos ao bioma Mata Atlântica, uma vez que a Serra do Mar concentra grande parte dos 5\% dos remanescentes de Mata Atlântica do Brasil, e aos manguezais existentes, indispensáveis à subsistência das populações tradicionais das zonas costeiras. Certamente, os efeitos do empreendimento, assim como de todo o pólo industrial de Cubatão iriam recair sobre a Unidade de Conservação da Serra do Mar.

É contraditório, no entanto, que, mesmo tendo sido considerada nas décadas de 80 e 90 a cidade mais poluída do mundo, devido à baixa taxa de dispersão dos poluentes atmosféricos imposta pela barreira natural da Serra do Mar, Cubatão tenha sido a alternativa locacional proposta para instalação de tal empreendimento.

Como justificativa foi apresentado no EIA que a instalação da UTE CCBS objetivava a auto-suficiência energética da RPBC. Sabe-se, porém, que a potência instalada seria para geração de uma quantidade de energia muito superior a esta autosuficiência o que permitiria a comercialização de quase $90 \%$ da energia que seria gerada. 
No EIA apresentado não foram realizados estudos de alternativas locacionais, tampouco foram considerados critérios ambientais na escolha do local proposto para instalação da usina que pudessem conferir ao projeto maior viabilidade ambiental.

É importante mencionar que, além de instituir critérios de acordo com a tipologia do empreendimento a ser licenciado para a determinação da obrigatoriedade de elaboração de EIA e respectivo RIMA, a Resolução CONAMA 001/86 em seu Art. $5^{\circ}$ também estabelece diretrizes gerais e exigências mínimas quanto ao conteúdo de tais estudos. Dentre estas exigências o EIA deve "contemplar todas as alternativas tecnológicas e de localização confrontando-as com a hipótese de não execução do projeto".

A necessidade de apresentação do estudo de alternativas locacionais no EIA torna-se ineficaz ao que se propõe - escolha da alternativa ambientalmente mais viável - quando a localização proposta para instalação do empreendimento termelétrico já encontra-se definida pelos investidores junto ao Ministério de Minas e Energia (MME) em momento prévio ao licenciamento ambiental. Nestes casos, assim como observado neste EIA analisado, o estudo de alternativas locacionais, apesar de intitulado desta forma, apresenta-se apenas como uma descrição da localização já definida para a instalação do empreendimento, sem que sejam identificadas quaisquer outras alternativas. Em outros casos, são consideradas alternativas locacionais evidentemente inferiores do ponto de vista ambiental, o que conseqüentemente torna a localização pretendida a alternativa mais adequada.

Em que se pesem as controvérsias, o estudo de alternativas locacionais configura-se atualmente por uma exigência legal que deve ser abordado no EIA e que, sem o qual, o órgão ambiental responsável pela análise do mesmo deveria solicitar a reelaboração ou até mesmo proceder na reprovação do EIA apresentado.

Romero (2002) afirma que " a ausência de análises de alternativas locacionais e tecnológicas tem reduzido os EIAs à identificação de medidas mitigadoras e/ou compensatórias de decisões técnicas e políticas previamente adotadas".

Apesar de todas estas contradições que poderiam ter levado à conclusão da inviabilidade ambiental do empreendimento por parte do DAIA, dadas as condições do local proposto, ou ainda, a necessidade de reelaboração do EIA por não apresentar 
um estudo de alternativas locacionais, uma exigência legal, a LP $\mathrm{n}^{0} 381$ foi concedida em 01/02/2001.

Como já mencionado anteriormente, foi concedida a LI nº 214 em 19/10/2001 e atualmente a UTE, que recebeu o nome de Euzébio Rocha, encontra-se em construção com algumas alterações ao projeto inicial e com previsão para entrar em operação a partir do segundo semestre de 2008. 


\subsubsection{UTE Santa Branca}

As principais características do empreendimento encontram-se descritas no Quadro 5.5.

\begin{tabular}{|c|c|}
\hline Empreendimento & Usina Termelétrica Santa Branca \\
\hline Número do processo no DAIA & SMA 13.696/1999 (SMA, 1999) \\
\hline Município & Santa Branca \\
\hline Empreendedor & Eletroger Ltda. \\
\hline Local de implantação & $\begin{array}{l}\text { Área de } 120.000 \mathrm{~m}^{2} \text {, adjacente à represa da } \\
\text { UHE Santa Branca, conforme Figura } 5.5 .\end{array}$ \\
\hline Coordenadas & $23^{\circ} 23^{\prime} \mathrm{S} ; 45^{\circ} 52^{\prime} \mathrm{W}$ \\
\hline Potência Instalada & $1.067 \mathrm{MW}$ \\
\hline Combustível & 4,8 milhões $\mathrm{m}^{3} /$ dia de gás natural \\
\hline Investimento & US $\$ 600$ milhões \\
\hline Rio para captação & Paraíba do Sul \\
\hline $\begin{array}{l}\text { Intervenção em Unidade de } \\
\text { Conservação }\end{array}$ & APA Mananciais do Paraíba do Sul (Federal) \\
\hline Restrições Ambientais destacadas & $\begin{array}{l}\text { - Intervenção em patrimônio ecológico do } \\
\text { município de Santa Branca } \\
\text { - Área destinada à recuperação ambiental }\end{array}$ \\
\hline Previsão para ser instalada & 2001 \\
\hline Licença Ambiental Prévia & LP no 470 de 08/02/2002 (cancelada) \\
\hline Observações & $\begin{array}{l}\text { - Inscrita no PPT (Usina a gás natural em ciclo } \\
\text { combinado, conforme Portaria 43/2000); } \\
\text { - Contemplado pela Medida Provisória n } \\
\text { 2147/2001. }\end{array}$ \\
\hline
\end{tabular}

Quadro 5.5. Principais características da UTE Santa Branca.

A Tabela 5.3 representa a caracterização do processo de licenciamento ambiental da UTE Santa Branca junto ao DAIA (Processo SMA 13.696/1999), frente aos fatores selecionados, desde a apresentação do RAP até a concessão da LP. 


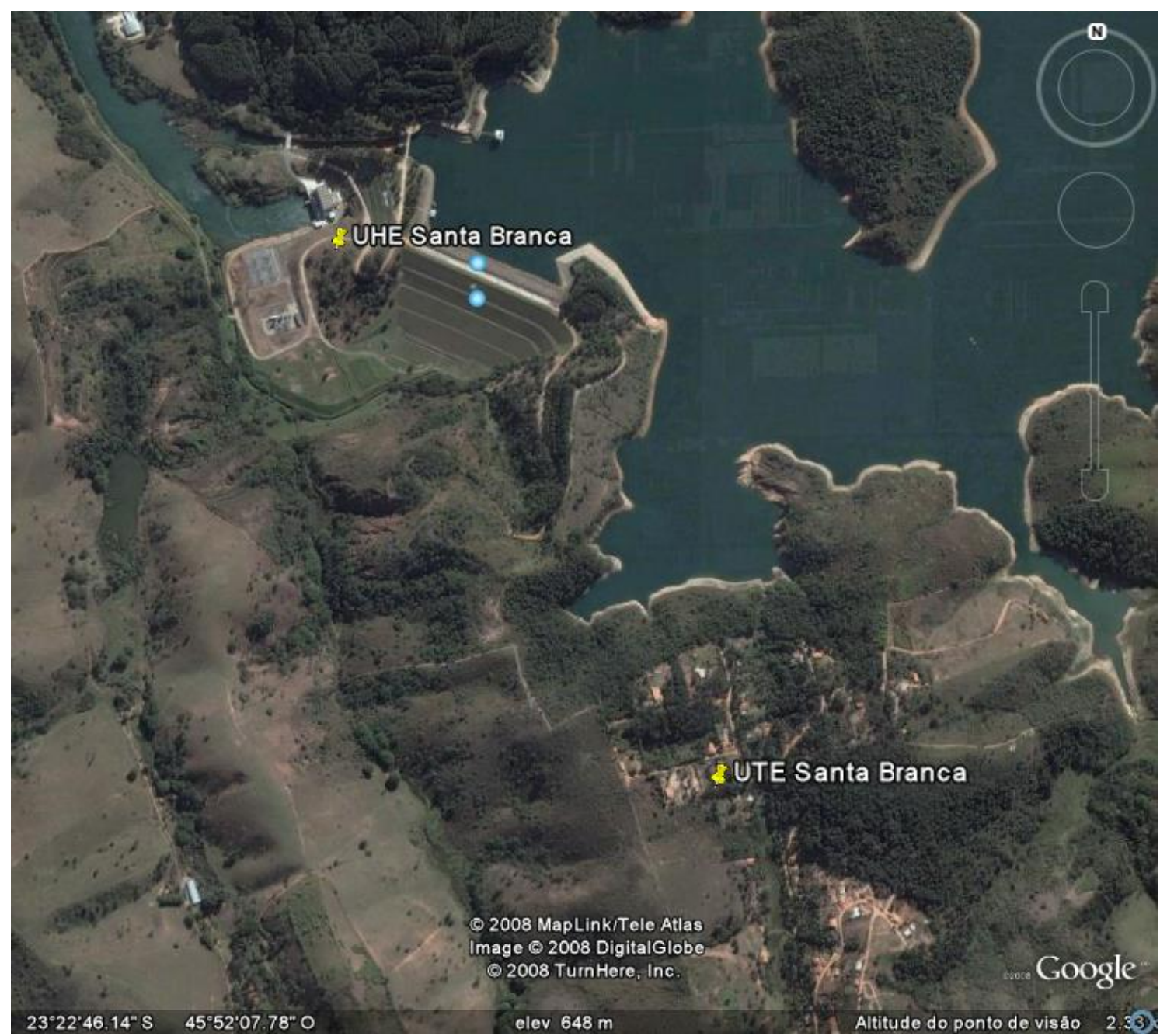

Figura 5.5. Localização proposta para implantação da UTE Santa Branca (extraído de Google Earth).

Tabela 5.3. Caracterização do processo SMA 13.696/1999 frente aos fatores selecionados.

\begin{tabular}{|l|c|}
\hline \multicolumn{1}{|c|}{ Fatores selecionados } & Quantificação \\
\hline Número de solicitação de informações complementares & 02 \\
\hline Número de impactos ambientais identificados no EIA/RIMA & 38 \\
\hline Número de condicionantes constantes na LP expedida & 67 \\
\hline
\end{tabular}

Observa-se (Tabela 5.4 e Figura 5.6) que, do tempo total de tramitação do processo (992 dias), 55\% ficaram sob análise quer seja do DAIA, Cetesb, Consema, Comitê de Bacia ou IBAMA. Para uma análise criteriosa dos diferentes aspectos ambientais que sofrem interferência quando da implantação de uma usina termelétrica, é necessário demanda e envolvimento de diferentes órgãos internos ou não ao SISNAMA. A Cetesb foi responsável pela análise dos aspectos relacionados às emissões atmosféricas (incluindo-se estudos de dispersão), ruído e vibrações, 
resíduos sólidos industriais e análise de risco. Ao Comitê de Bacia coube a análise quanto à disponibilidade e usos do corpo hídrico, mas, de acordo com os registros desse processo, apesar da solicitação oficial feita por parte do DAIA, não houve manifestação por parte do Comitê.

Do tempo total de tramitação sob a responsabilidade do empreendedor (387 dias), 254 dias $(65,6 \%)$ foram utilizados pelo empreendedor para a elaboração e reelaboração do Plano de Trabalho, 119 dias (30,7\%) para elaboração do EIA/RIMA, e os 14 dias restantes foram utilizados para atendimento à solicitação de informações complementares ao EIA feita pela Cetesb relativas aos aspectos de emissões atmosféricas, climatologia, modelo de dispersão, poluição sonora, efluentes líquidos, resíduos sólidos, águas subterrâneas, solo e análise de risco.

Tabela 5.4. Análise dos tempos de tramitação do processo SMA 13.696/1999.

\begin{tabular}{|l|c|}
\hline \multicolumn{1}{|c|}{ Tempos de tramitação } & Quantificação \\
\hline Tempo total de tramitação do processo até a obtenção da LP & 992 dias* $^{\star}$ \\
\hline Tempo total de tramitação que depende do empreendedor & 387 dias \\
\hline Tempo total de tramitação que independe de ação do empreendedor & 547 dias \\
\hline
\end{tabular}

* neste processo o tempo total de tramitação inclui 58 dias em que a análise foi suspensa devido à liminar concedida pelo Poder Judiciário à Ação Civil Pública requerida pelo Ministério Público em face da Fazenda Pública Estadual.

Do tempo total em cada agente do processo (Figura 5.7) é necessário ressaltar que existe uma sobreposição de atuação dos agentes, ou seja, enquanto o processo encontra-se sob análise de um agente também o poderá estar em análise em outro, o que pode ser claramente observado na Figura 5.8, ou ainda que, somando-se o tempo em cada agente o resultado é superior ao tempo total de tramitação do processo. Isto acontece com muita freqüência quando o DAIA, feita sua análise, somente poderá dar publicidade ao parecer técnico final quando receber a manifestação de outro órgão demandado.

O Ministério Público interveio neste processo através de duas Ações Civis Públicas as quais foram concedidas liminares pelo Poder Judiciário, o que evidentemente interferiram na tramitação do processo, uma vez que não somente resultaram na suspensão da análise por 58 dias como também cancelaram a LP concedida. 


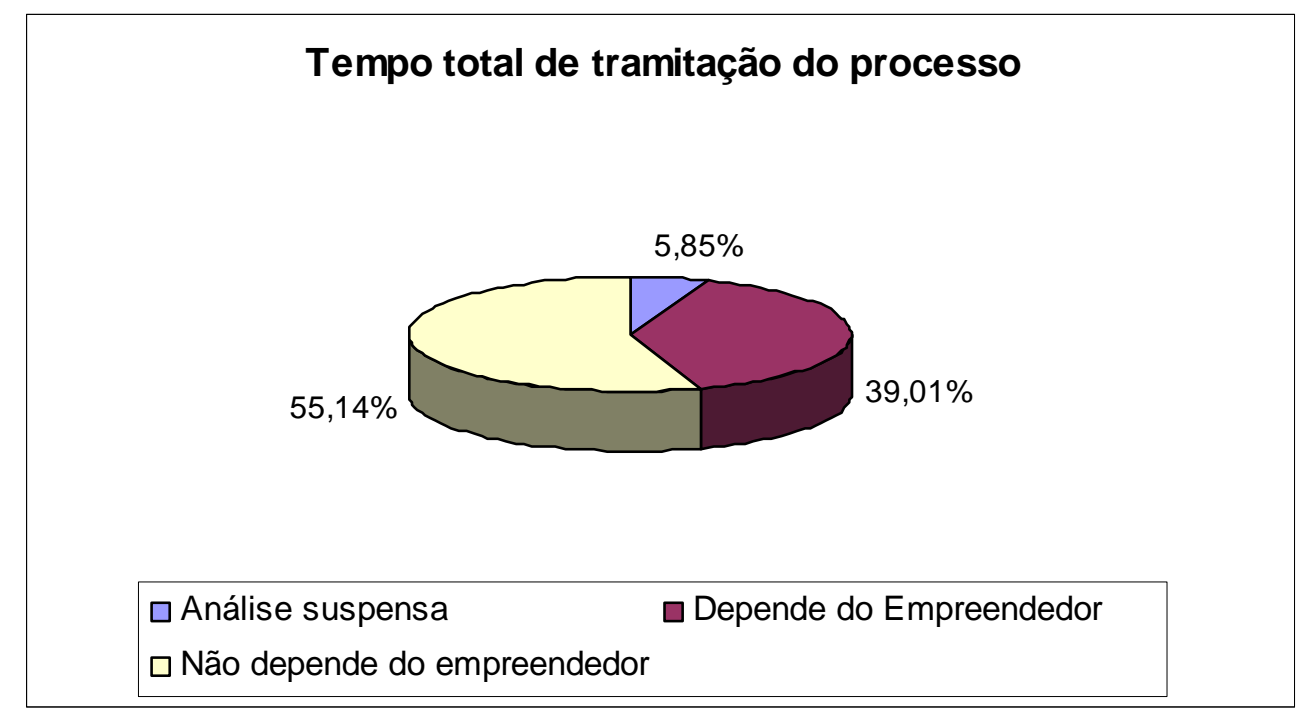

Figura 5.6. Tempo total de tramitação do processo SMA 13.696/1999.

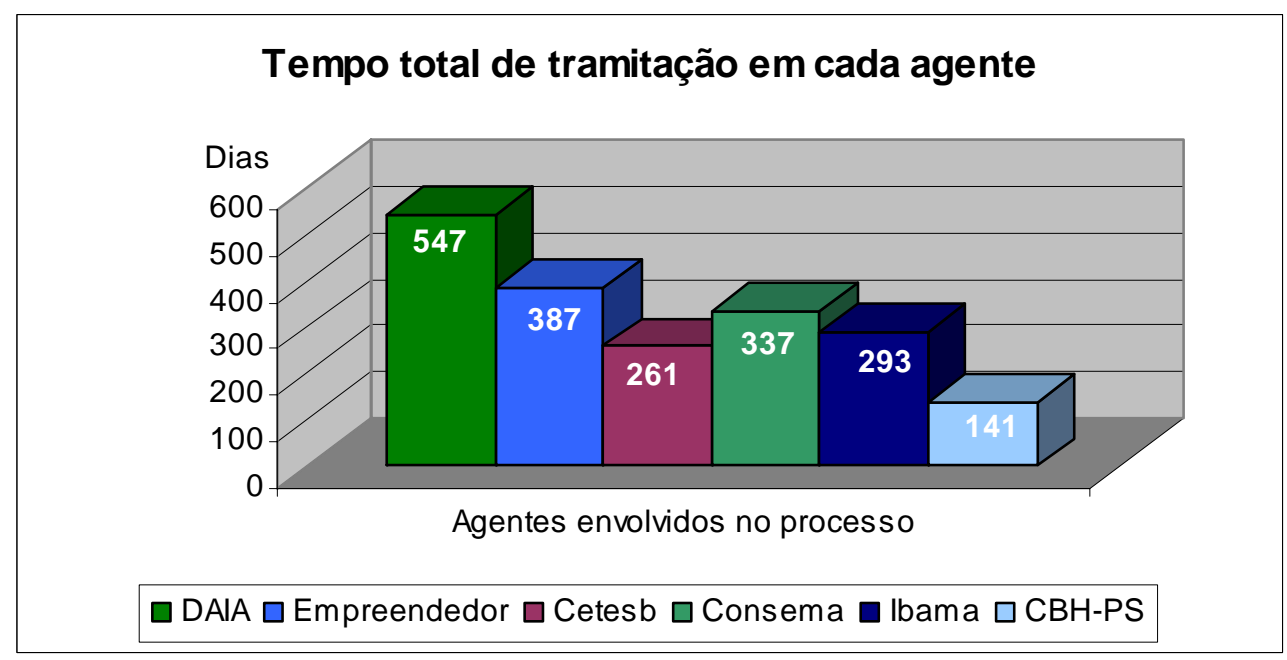

Figura 5.7. Tempo total de tramitação em cada agente envolvido no processo SMA 13.696/1999.

A Figura 5.8 representa todo o trâmite do processo e por meio desta pode ser visualizada a atuação dos diferentes agentes envolvidos e o tempo que cada agente foi demandado no processo de licenciamento ambiental da UTE Santa Branca. 


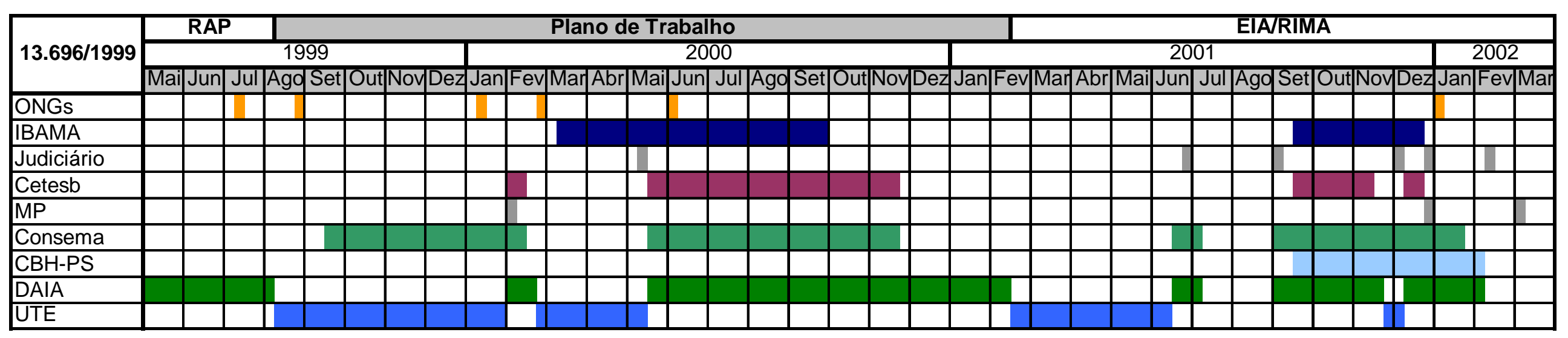

Figura 5.8. Representação da tramitação do processo de licenciamento ambiental da UTE Santa Branca (SMA 13.696/1999) 


\section{Fatores qualitativos que podem ter interferido no tempo de tramitação do processo:}

Durante a análise do Plano de Trabalho, o DAIA constatou que, apesar de erroneamente informado no RAP pag. 43, a alternativa locacional proposta para instalação da UTE situava-se dentro dos limites da Área de Proteção Federal (APA) Mananciais do Paraíba do Sul e, em atendimento ao disposto na Resolução Conama no 10/88, foi solicitado manifestação ao IBAMA que, por sua vez, concedeu a Licença Especial n 04/2001 para a instalação do empreendimento dentro dos limites da referida APA.

Muito atuante neste processo, o Ministério Público entrou com Ação Civil Pública contra a Light Serviços de Eletricidade S/A, empresa responsável pela Usina Hidrelétrica (UHE) Santa Branca, tendo em vista que a alternativa locacional proposta para a implantação da UTE caracterizava-se por uma área destinada à recuperação ambiental (conforme LI no 0031 de 19/03/1997, concedida à Light Serviços de Eletricidade S/A para o empreendimento UHE Santa Branca). Foi determinado por medida liminar que a Light não desse outra destinação à área que não fosse a plena e inequívoca recuperação ambiental e, diante disso, o DAIA suspendeu a análise do pedido de licença ambiental prévia por 58 dias.

Dadas as circunstâncias emergenciais impostas pela Medida Provisória $n^{\circ}$ 2.147 de 15 de maio de 2001 (Anexo 3), que, em seu Art. $8^{\circ} \S 2^{\circ}$, estabeleceu em cenário nacional o prazo máximo de 4 (quatro) meses para o licenciamento ambiental de empreendimentos termelétricos, foi emitido pelo Secretário do Meio Ambiente a seguinte Informação Técnica AT/CPRN de 03/09/2001 dirigida ao DAIA: "[...] Cabe lembrar que esta Administração tem o dever legal de dar prosseguimento aos licenciamentos em curso, sob pena de estar infringido direito líquido e certo do particular [...]" (SMA, 1999), portanto foi reiniciada a análise pelo DAIA em 03/09/2001.

Devido ao prosseguimento dado ao processo, o Ministério Público entrou com outra Ação Civil Pública, agora contra a Fazenda Pública Estadual, baseando-se na Lei Orgânica do município de Santa Branca em seu Art. 166, que estabelece que o rio Paraíba do Sul, seus limites, afluentes e a represa existente são tidos como patrimônio ecológico do município e insusceptíveis de outra destinação. 
A empresa Eletroger, responsável pelo projeto da usina, afirmou que o patrimônio ambiental não seria afetado e que os técnicos da empresa estavam realizando estudos, levando em consideração as restrições ambientais impostas pelo local. Também justificou a instalação da usina pela quantidade de empregos que seriam gerados, 500 empregos diretos durante a fase de construção e outros 50 em 2003, após entrar em operação.

Alegando, portanto, que a SMA descumpria os ditames legais da Lei Orgânica do município de Santa Branca prosseguindo com o licenciamento ambiental, o objeto da Ação Civil Pública era que fosse determinado liminarmente a abstenção de conceder qualquer licença, fosse LP, LI ou LO para a UTE Santa Branca, e a revogação das licenças, caso já tivessem sido concedidas, bem como fosse oficiado à Polícia Florestal, Polícia Militar local e autoridade policial de Santa Branca para que fiscalizassem o cumprimento da medida liminar a ser concedida, e enviassem ao Juízo relatórios semanais das fiscalizações realizadas.

Aos conhecimentos da SMA sobre a Ação Civil Pública, a Consultoria Jurídica desta apresentou informações como as que seguem:

[...] todavia, antes de ser "patrimônio ecológico da cidade", o rio Paraíba do Sul é de domínio da União, visto que banha mais de um estado [...] Logo, é forçoso admitir que a edição de lei municipal, neste particular, invade o campo de competência legislativa da União e desrespeita, via de conseqüência, o Princípio da Independência dos Poderes, agasalhada pela Constituição Federal.

[...] nada impede que a lei local diga que o rio Paraíba é patrimônio ecológico do município de Santa Branca, nos limites e afluentes, pois para isso tem competência concorrente ou suplementar. Todavia, inapropriado dizer que suas águas são "insusceptíveis de outra destinação". Isto porque não diz qual a destinação admitida que impeça "a outra", e, sobretudo, porque não cabe ao município definir os usos das águas, pois dela não tem domínio. As águas são federais ou estaduais e sua gestão se faz por meio do Sistema Federal ou Estadual de Gerenciamento dos Recursos Hídricos, que, através dos respectivos Comitês e Planos de Bacia, estabelecerão os usos (MILARÉ (...) apud SMA, 1999). 
Nesse sentido, a Consultoria Jurídica considerou que não perfazia motivo suficiente para impedir a implantação do empreendimento em questão e, então, o Consema por meio de deliberação, manifestou-se favorável à viabilidade ambiental do empreendimento UTE Santa Branca e foi emitida a Licença Ambiental Prévia no 00470 em 08/02/2002, a qual aprovou a localização e concepção do empreendimento.

Observa-se que, apesar da alternativa locacional proposta para implantação da usina termelétrica ser:

- considerada patrimônio ambiental do município de Santa Branca, conforme Lei Orgânica de 05/04/1990 em seu Art. 166;

- destinada à recuperação ambiental, conforme Parecer Técnico CPRN/DAIA/51/97 e LI nº 0031 de 19/03/1997 concedida à Light Serviços de Eletricidade S/A para o empreendimento Usina Hidrelétrica Santa Branca; e

- inserida em uma Unidade de Conservação Federal (APA Mananciais do Paraíba do Sul),

a licença ambiental prévia foi concedida, a qual aprovou a localização e concepção do empreendimento por entender que este empreendimento era ambientalmente viável.

Após a emissão da licença, segundo consta no processo analisado, foi concedida a medida liminar pelo Poder Judiciário e, portanto, a SMA foi obrigada a revogar a licença.

O empreendedor, tomando conhecimento do cancelamento da licença, entrou com recursos solicitando reconsideração, porém, a Consultoria Jurídica da SMA, por meio de Parecer justificado, considerou os pedidos indeferidos e a licença prévia permaneceu cancelada. 


\subsubsection{UTE Duke Energy 1}

As principais características do empreendimento encontram-se descritas no Quadro 5.6.

\begin{tabular}{|c|c|}
\hline Empreendimento & UTE Duke Energy I \\
\hline Número do processo no DAIA & SMA $13.629 / 2000$ (SMA, 2000a) \\
\hline Município & Pederneiras \\
\hline Empreendedor & Duke Energy 1 Brasil Ltda. \\
\hline Local de implantação & $\begin{array}{l}\text { Área de } 100 \text { ha, em propriedade rural junto a } \\
\text { Rodovia SP } 261 \text { que liga Pederneiras a Bauru. }\end{array}$ \\
\hline Coordenadas & $22^{\circ} 23^{\prime} 42.58^{\prime \prime} \mathrm{S} ; 48^{\circ} 44^{\prime} 33.79^{\prime \prime W}$ \\
\hline Potência Instalada & $\begin{array}{l}500 \text { MW (suficiente para abastecer uma cidade } \\
\text { com 1,4 milhão de habitantes, ou seja, 40x } \\
\text { maior do que a de Pederneiras). }\end{array}$ \\
\hline Combustível & 2 milhões de $\mathrm{m}^{3} /$ dia de gás natural \\
\hline Investimento & US\$ 250 milhões \\
\hline Rio para captação & $\begin{array}{l}\text { Ribeirão dos Patos (braço do Reservatório da } \\
\text { UHE Bariri) }\end{array}$ \\
\hline $\begin{array}{l}\text { Intervenção em Unidade de } \\
\text { Conservação }\end{array}$ & não \\
\hline $\begin{array}{l}\text { Restrições Ambientais } \\
\text { destacadas }\end{array}$ & $\begin{array}{l}\text { De acordo com o EIA, não existiam. A proposta } \\
\text { locacional caracterizava-se por: } \\
\text { - área com predominância de plantio de cana e } \\
\text { pasto, conforme Figura } 5.9 \text { e Figura 5.10; } \\
\text { - área de Distrito Industrial, disciplinada na } \\
\text { época conforme Lei Complementar } n^{\circ} \\
2.163 / 2000 \text {. }\end{array}$ \\
\hline Previsão para ser instalada & 2003 \\
\hline Licença Ambiental Prévia & LP no 00457 de 19/12/2001 \\
\hline Observações & $\begin{array}{l}\text { - Inscrita no PPT (Usina a gás natural em ciclo } \\
\text { combinado, conforme Portaria 43/2000); } \\
\text { - Contemplado pela Medida Provisória n } \\
\text { 2147/2001. }\end{array}$ \\
\hline
\end{tabular}

Quadro 5.6. Principais características da UTE Duke Energy 1.

De acordo com o EIA/RIMA apresentado no DAIA, para escolha da localização, dentre as alternativas levantadas para a implantação da usina, foram considerados critérios como proximidade do mercado consumidor, afastamento de centros urbanos, suprimento de gás natural, disponibilidade hídrica, facilidade de integração à rede de distribuição, receptividade da população frente à proposta de implantação da UTE e facilidade de acesso à usina. 


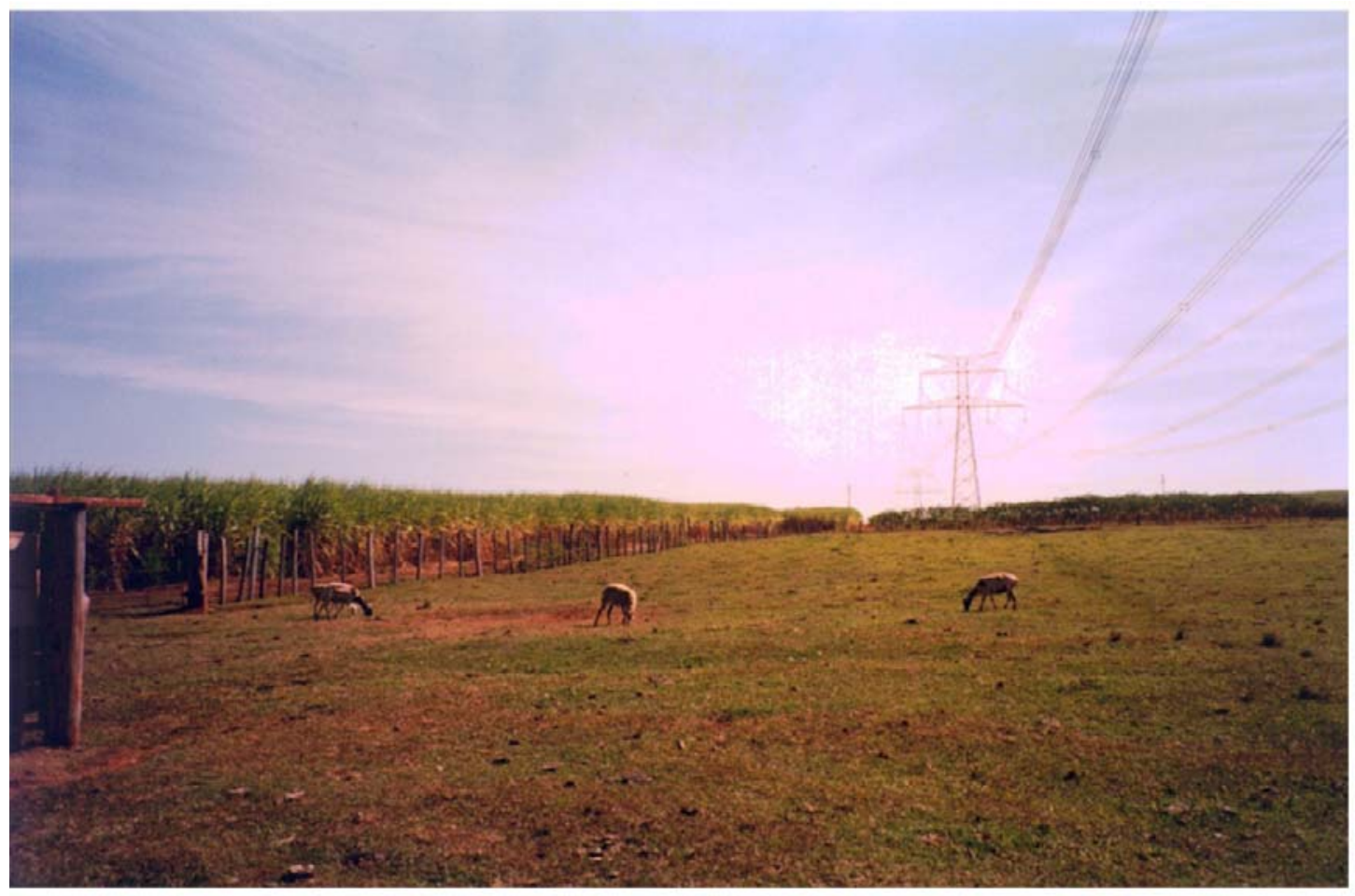

Figura 5.9. Área proposta para implantação da UTE Duke Energy 1.

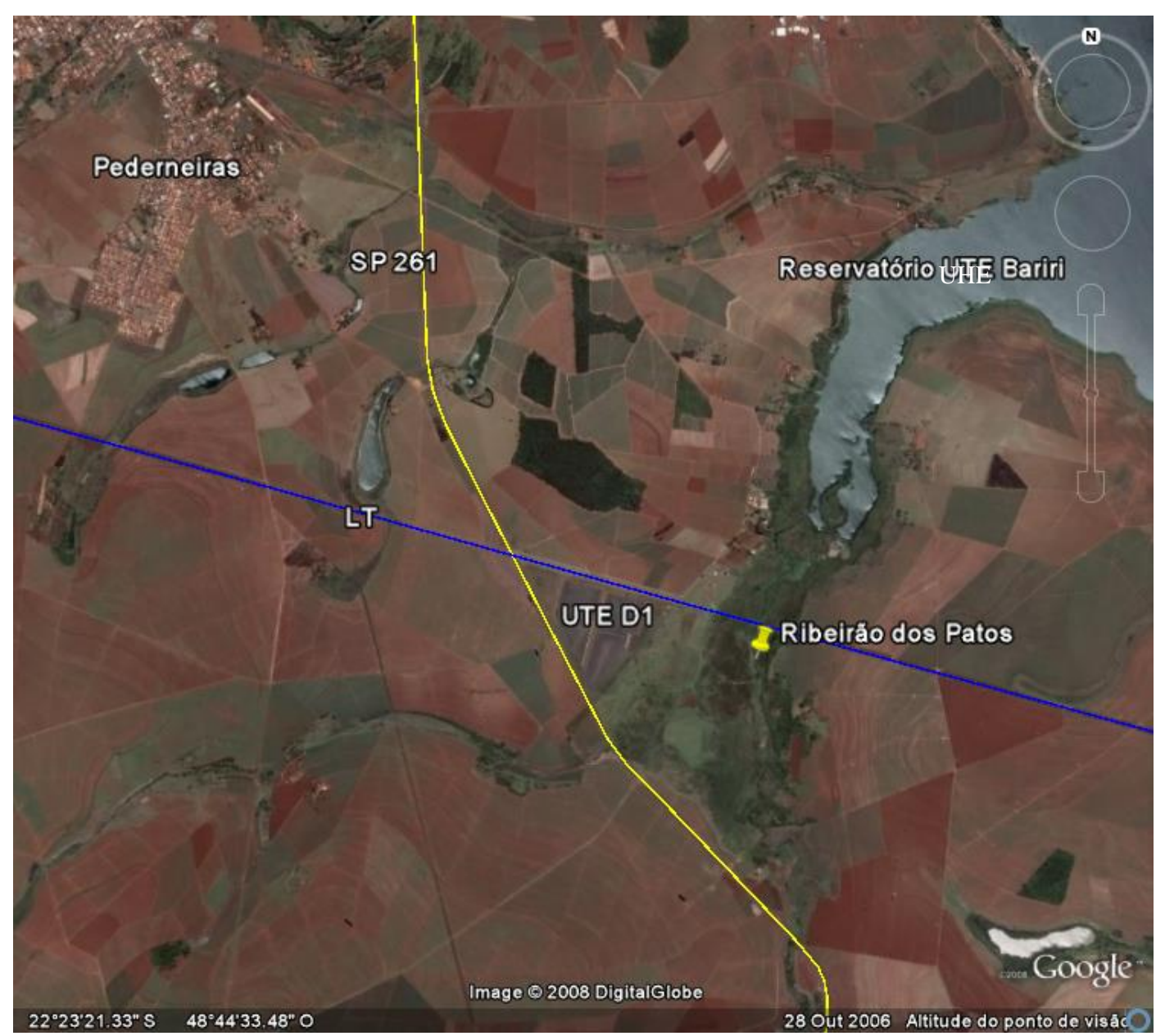

Figura 5.10. Proposta locacional para instalação da UTE Duke 1 (extraído de Google Earth). 
Na época, a distribuidora Gas Brasiliano reviu o projeto de construção da rede de distribuição do gás natural que, até então, não passava pelo município de Pederneiras, mas o volume que seria absorvido pela termelétrica, cerca de 2 milhões de $\mathrm{m}^{3} /$ dia, justificava a mudança de planos.

A ANEEL, por meio da Resolução $n^{\circ}$ 185, de 6 junho de 2000, autorizou a empresa Duke Energy 1 Brasil Ltda a implantar a central geradora termelétrica. Porém, em 2002, os investidores suspenderam o projeto alegando não haver quantidade suficiente de gás natural disponível no país para suprir as térmicas e, a pedido do própria empreendedor, esta resolução foi revogada pela Resolução $n^{0} 120$ de 25 de março de 2003.

A Tabela 5.5 representa a caracterização do processo de licenciamento ambiental da UTE Duke Energy 1 junto ao DAIA (Processo SMA 13.629/2000), frente aos fatores selecionados, desde a apresentação do RAP até a concessão da LP.

Tabela 5.5. Caracterização do processo SMA 13.629/2000 frente aos fatores selecionados.

\begin{tabular}{|l|c|}
\hline \multicolumn{1}{|c|}{ Fatores selecionados } & Quantificação \\
\hline Número de solicitação de informações complementares & 2 \\
\hline Número de impactos ambientais identificados no EIA/RIMA & 33 \\
\hline Número de condicionantes constantes na LP expedida & 40 \\
\hline
\end{tabular}

Do tempo total de tramitação do processo (493 dias), 82,8\% não ficaram sob a responsabilidade do empreendedor (Tabela 5.6 e Figura 5.11), ou seja, o processo ficou sob análise do DAIA ou de outros agentes envolvidos no processo. Do tempo total de tramitação que independe do empreendedor (408 dias), observa-se (Figura 5.12 e Figura 5.13) que existe uma grande possibilidade de que o DAIA tenha ficado aguardando manifestação da Cetesb, em especial durante a fase de Plano de Trabalho, para emissão do Termo de Referência.

Tabela 5.6. Análise dos tempos de tramitação do processo SMA 13.629/2000.

\begin{tabular}{|l|c|}
\hline \multicolumn{1}{|c|}{ Tempos de tramitação } & Quantificação \\
\hline Tempo total de tramitação do processo até a obtenção da LP & 493 dias \\
\hline Tempo total de tramitação que depende do empreendedor & 85 dias \\
\hline Tempo total de tramitação que independe de ação do empreendedor & 408 dias \\
\hline
\end{tabular}




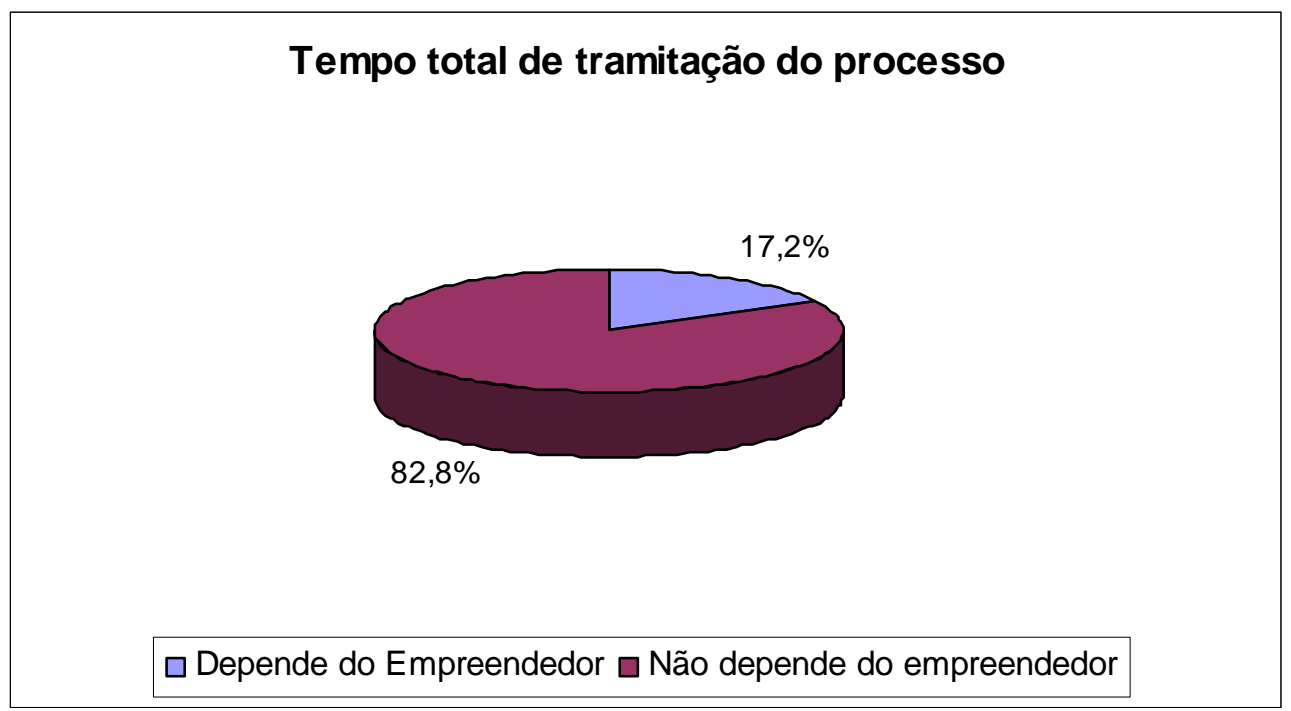

Figura 5.11. Distribuição do tempo total de tramitação do processo SMA 13.629/2000 entre os dois principais grupos de agentes (empreendedor e órgãos governamentais).

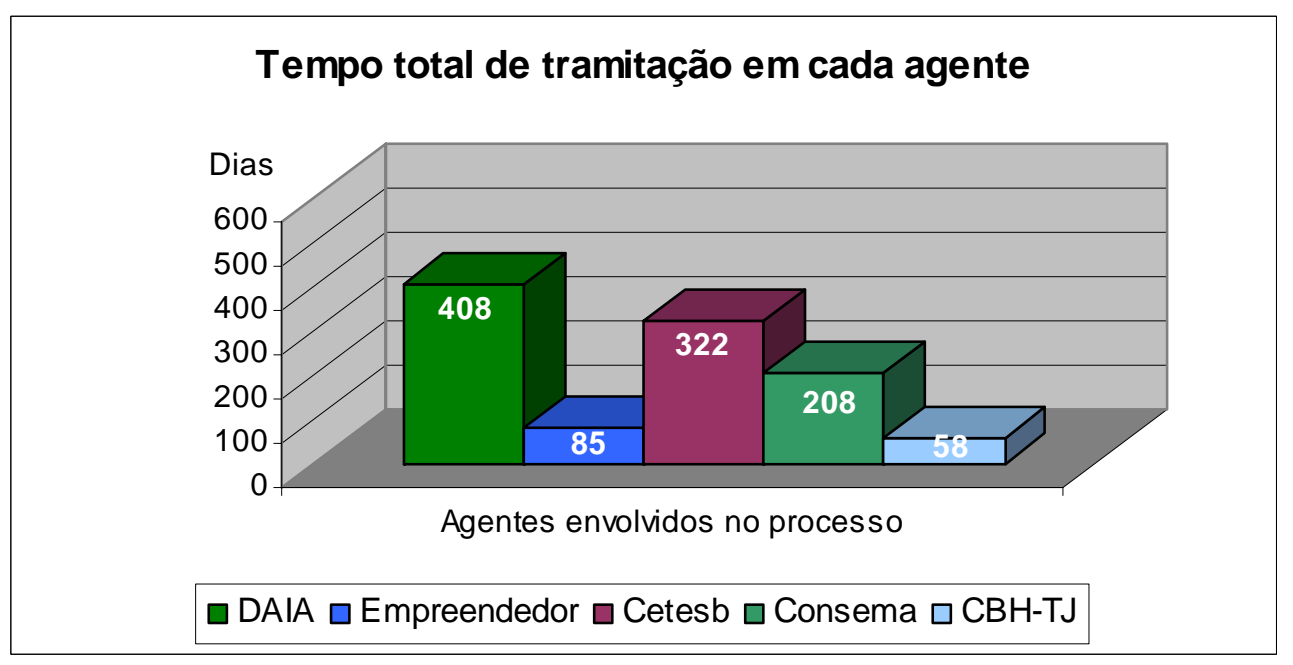

Figura 5.12. Tempo total de tramitação em cada agente envolvido no processo SMA $13.629 / 2000$.

Na Figura 5.13, que representa graficamente todo o trâmite do processo, pode ser visualizada a atuação dos diferentes agentes envolvidos e o tempo que cada agente foi demandado no processo de licenciamento ambiental da UTE Santa Branca.

Como pode ser observado pela Figura 5.13, enquanto o empreendedor providenciava as informações complementares solicitadas pela Cetesb, portanto, o tempo de tramitação do processo estava sob responsabilidade do empreendedor, o Comitê e o Consema davam continuidade à análise, por entenderem que as informações apresentadas encontravam-se satisfatórias para suas respectivas manifestações. 


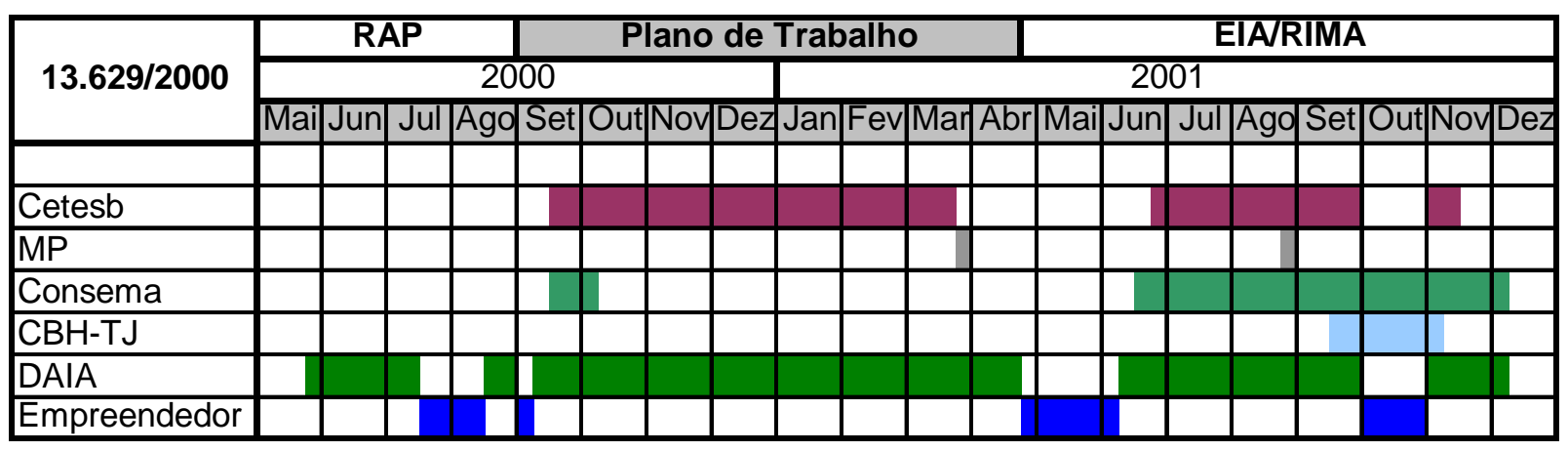

Figura 5.13. Representação da tramitação do processo de licenciamento ambiental da UTE Duke Energy 1 (SMA 13.629/2000).

\section{Fatores qualitativos que podem ter interferido no tempo de tramitação do processo:}

Neste processo, em especial, observa-se que o Ministério Público enviou contribuições para a análise do Plano de Trabalho e do EIA/RIMA. Os documentos encaminhados foram:

- Parecer Técnico elaborado por assessor técnico do Ministério Público, a partir da análise do Plano de Trabalho, contendo sugestões para o Termo de Referência;

- Informação Técnica elaborada por analistas periciais da Procuradoria da República no município de Bauru a fim de subsidiar a análise do EIA.

$\mathrm{O}$ CBH-TJ manifestou-se favoravelmente à implantação da UTE Duke Energy 1 e o empreendedor comprometeu-se com este a apresentar uma proposta de recuperação da mata ciliar do Ribeirão dos Patos deste a nascente, no município de Agudos, até o ponto de captação, no município de Pederneiras, onde seria instalada a usina. Também foi acordado que a empresa Duke Energy deveria dar prioridade no fomento a estudos para a implantação de corredores de fauna.

Pode ser observado que, durante o processo, não houve grandes discussões sobre a proposta locacional do empreendimento e que, de acordo com o número de impactos identificados e o número de condicionantes constantes na licença prévia expedida, pode-se supor que, ou o EIA tenha sido elaborado de forma satisfatória por meio da identificação do maior número possível de impactos e/ou as medidas mitigadoras propostas tenham sido eficazes, ou o empreendimento encontrava-se adequado ao local proposto. 


\subsubsection{UTE Carioba II}

As principais características do empreendimento encontram-se descritas no Quadro 5.7.

\begin{tabular}{|c|c|}
\hline Empreendimento & Usina Termelétrica Carioba II \\
\hline Número do processo no DAIA & SMA $13.545 / 2000$ (SMA, 2000b) \\
\hline Município & Americana \\
\hline Empreendedor & CPFL, Intergen do Brasil Ltda. e Shell \\
\hline Local de implantação & $\begin{array}{l}\text { Área de } 120.000 \mathrm{~m}^{2} \text { pertencente a empresa } \\
\text { Fibra, na divisa com Santa Bárbara d'Oeste } \\
\text { (conforme Figura 5.15). }\end{array}$ \\
\hline Coordenadas & $22^{\circ} 41^{\prime} 47.95^{\prime \prime S}, 47^{\circ} 21^{\prime} 43.19^{\prime \prime} \mathrm{W}$ \\
\hline Potência Instalada & $1.200 \mathrm{MW}$ \\
\hline Combustível & 6,4 milhões de $\mathrm{m}^{3} /$ dia de gás natural. \\
\hline Investimento & US\$ 600 milhões \\
\hline Rio para captação & Piracicaba \\
\hline $\begin{array}{l}\text { Intervenção em Unidade de } \\
\text { Conservação }\end{array}$ & não \\
\hline Restrições Ambientais destacadas & $\begin{array}{l}\text { - alternativa locacional em área próxima às } \\
\text { manchas urbanas dos municípios de } \\
\text { Americana e Santa Bárbara D'Oeste. }\end{array}$ \\
\hline Previsão para ser instalada & Não identificada \\
\hline Licença Ambiental Prévia & LP no 492 de 23/04/2002 \\
\hline Observações & $\begin{array}{l}\text { - Inscrita no PPT (Usina a gás natural em } \\
\text { ciclo combinado, conforme Portaria 43/2000); } \\
\text { - Contemplado pela Medida Provisória no } \\
\text { 2147/2001. }\end{array}$ \\
\hline
\end{tabular}

Quadro 5.7. Principais características da UTE Caroba II.

De acordo com o EIA apresentado, a área proposta para instalação da usina termelétrica encontrava-se regulamentada pela Lei Municipal no 3.271/99 em seu Art. 13, como sendo permitida a instalação de empreendimentos desta tipologia, porém, observa-se pela Figura 5.14 e Figura 5.15 a proximidade às manchas urbanas dos municípios de Americana e Santa Bárbara d’Oeste. 


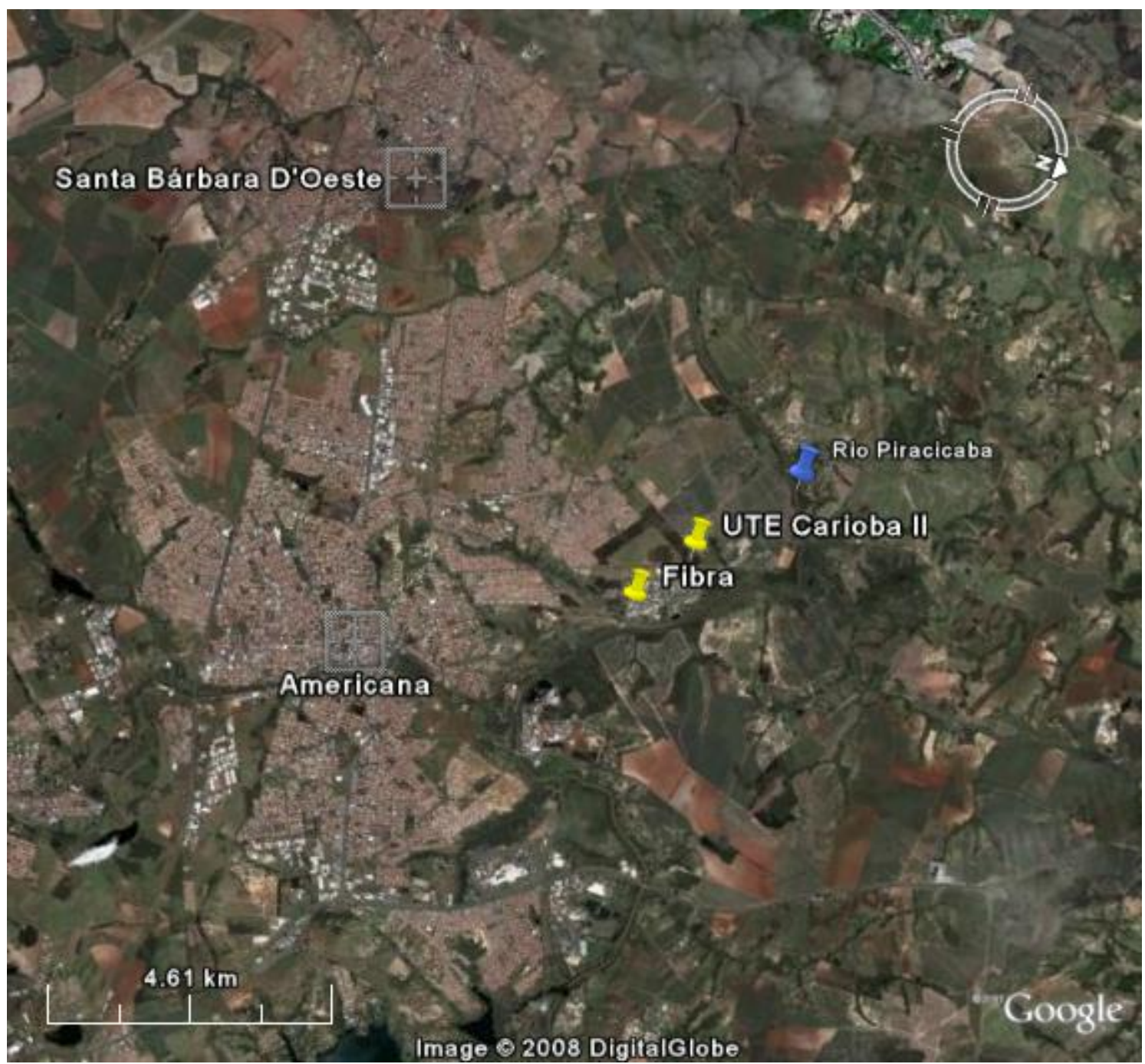

Figura 5.14. Proposta locacional para instalação da UTE Carioba II próxima às manchas urbanas dos municípios de Americana e Santa Bárbara D’Oeste.

A Tabela 5.7 representa a caracterização do processo de licenciamento ambiental da UTE Carioba II junto ao DAIA, frente aos fatores selecionados, desde a apresentação do RAP até a concessão da LP. Neste processo é importante destacar o número de solicitações feitas ao empreendedor tanto pelo DAIA, quanto pelos demais órgãos envolvidos no processo (Cetesb, Comitê de Bacia Hidrográfica dos rios Piracicaba, Capivari e Jundiaí (CBH-PCJ) e Consema). 


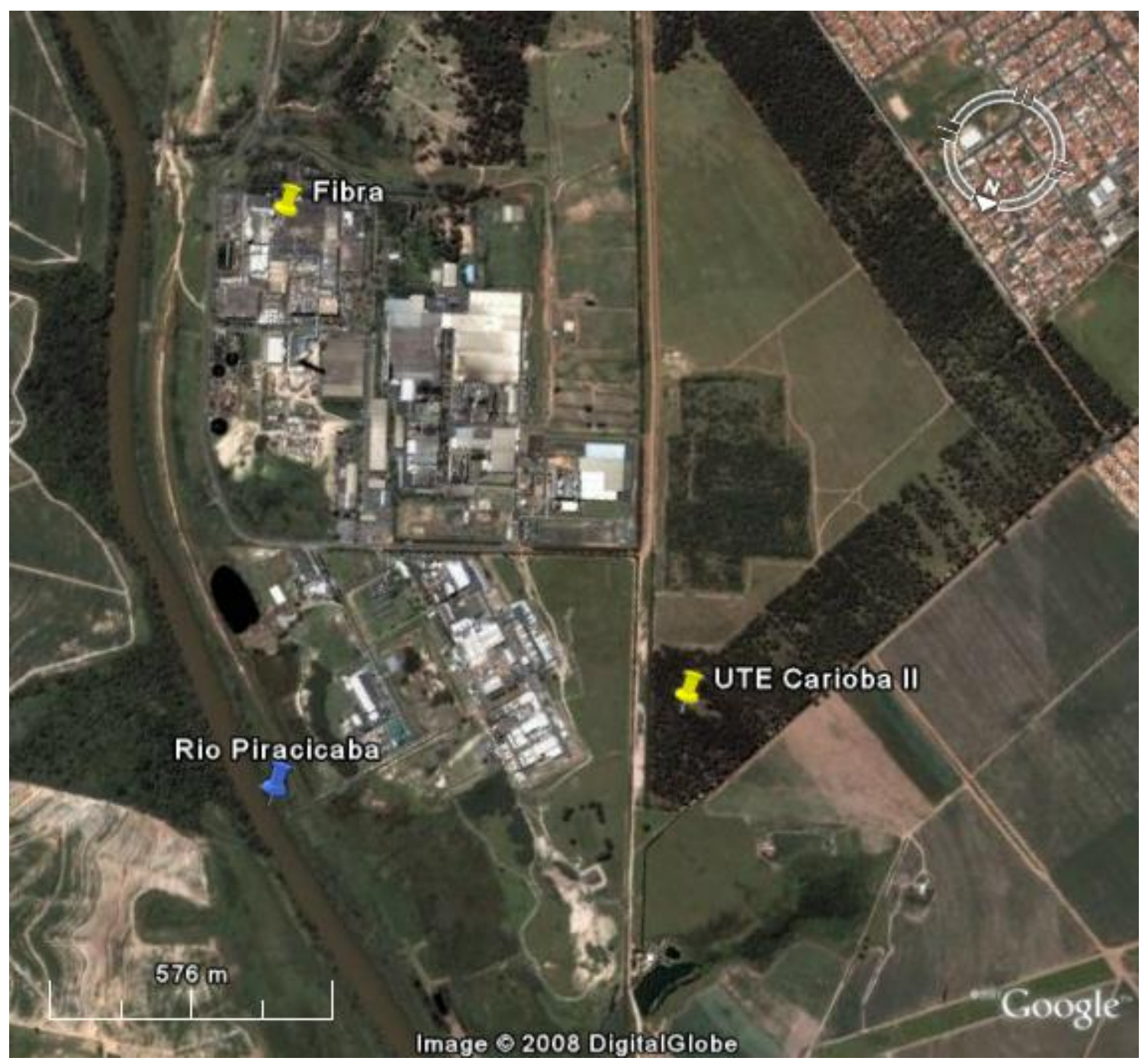

Figura 5.15. Alternativa locacional proposta em terreno pertencente à empresa Fibra (extraído de Google Earth)

Tabela 5.7. Caracterização do processo SMA 13.545/2000 frente aos fatores selecionados.

\begin{tabular}{|l|c|}
\hline \multicolumn{1}{|c|}{ Fatores selecionados } & Quantificação \\
\hline Número de solicitação de informações complementares & 12 \\
\hline Número de impactos ambientais identificados no EIA/RIMA & 29 \\
\hline Número de condicionantes constantes na LP expedida & 75 \\
\hline
\end{tabular}

Observa-se (Tabela 5.8 e Figura 5.16) que, do tempo total de tramitação do processo (771 dias), 64,9\% deste ficou sob responsabilidade dos órgãos estaduais, quer seja em análise no DAIA, Cetesb, Consema ou Comitê de Bacia. No tempo em que o processo tramitou sob responsabilidade do empreendedor, 271 dias, ou ainda, 1/3 do tempo total de tramitação do processo, foram contabilizados os tempos para elaboração de Plano de Trabalho e EIA/RIMA, e o tempo em que o empreendedor 
providenciava as informações complementares que foram solicitadas 12 vezes durante o processo, o que pode indicar grandes deficiências no estudo apresentado.

Pela Figura 5.18 é possível visualizar que enquanto o empreendedor providenciava as informações complementares solicitadas durante a fase de EIA/RIMA a análise continuava sendo feita pela Cetesb, Consema e Comitê de Bacia.

Tabela 5.8. Análise dos tempos de tramitação do processo SMA 13.545/2000.

\begin{tabular}{|l|c|}
\hline \multicolumn{1}{|c|}{ Tempos de tramitação } & Quantificação \\
\hline Tempo total de tramitação do processo até a obtenção da LP & 771 dias \\
\hline Tempo total de tramitação que depende do empreendedor & 271 dias \\
\hline Tempo total de tramitação que independe de ação do empreendedor & 500 dias \\
\hline
\end{tabular}

A Figura 5.17 representa o tempo total de tramitação em cada agente envolvido no processo. Durante a fase de Plano de Trabalho o empreendedor apresentou o documento ao comitê e solicitou manifestação deste externamente ao processo.

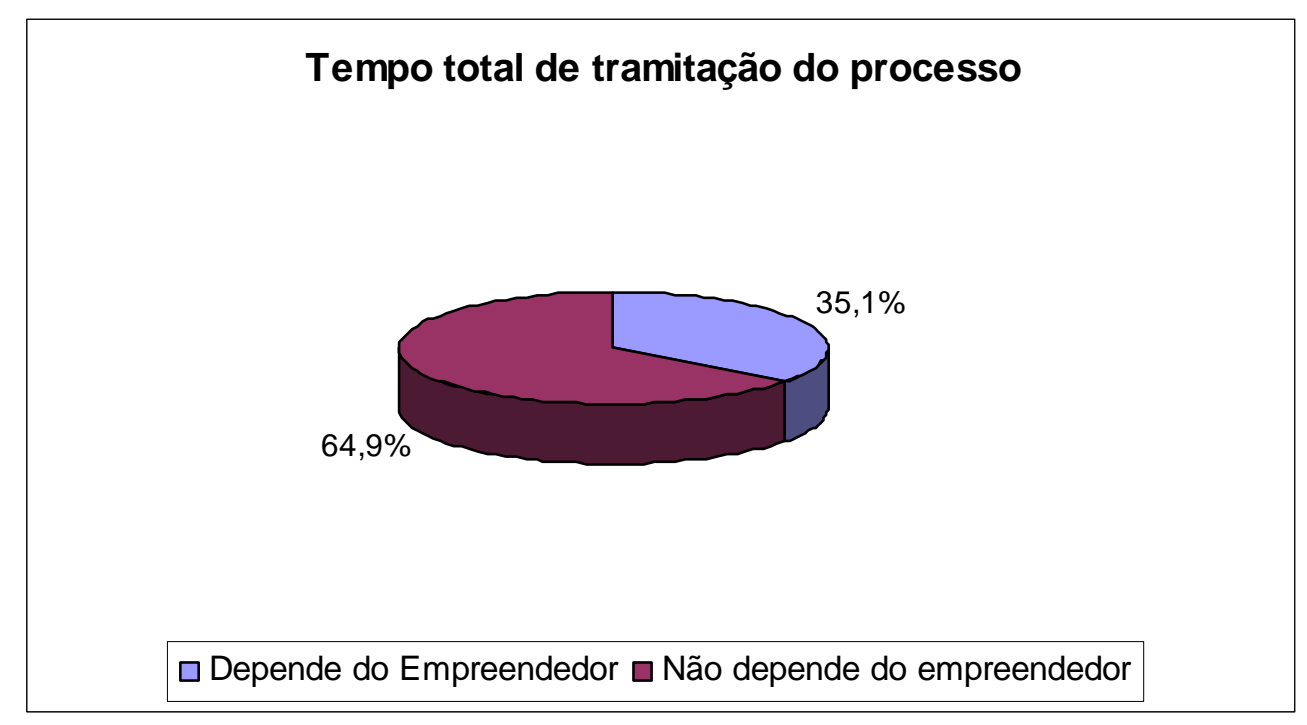

Figura 5.16. Tempo total de tramitação do processo SMA 13.545/2000. 


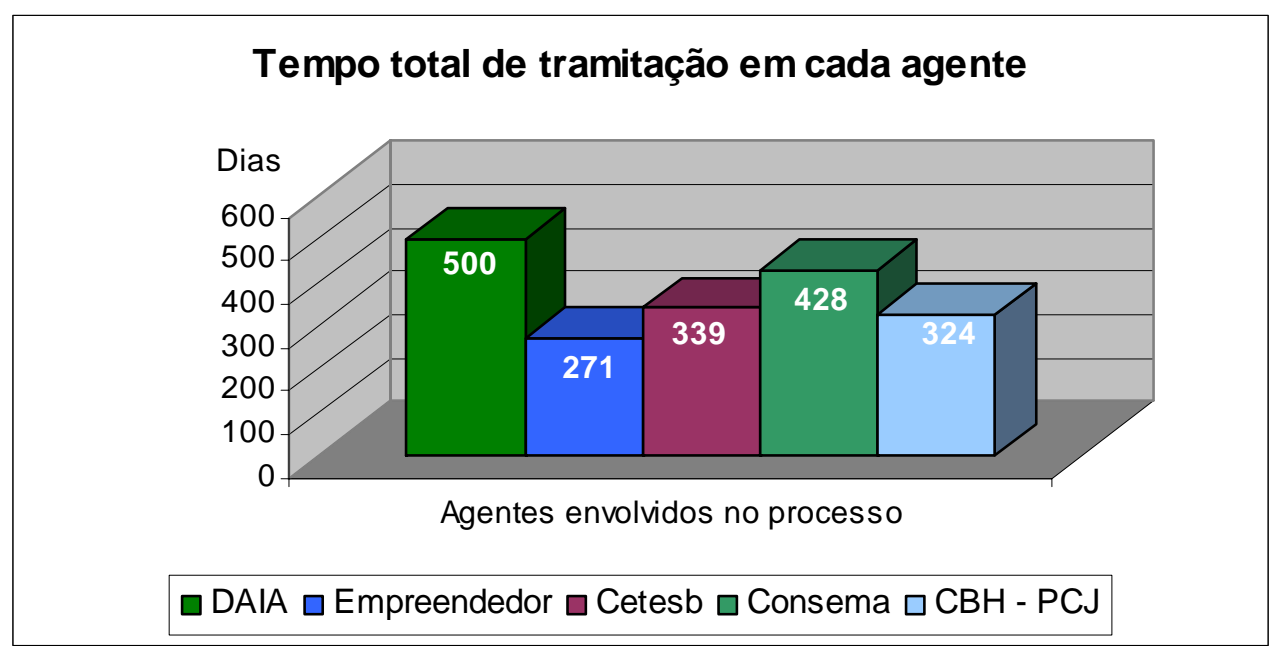

Figura 5.17. Tempo total de tramitação em cada agente envolvido no processo SMA $13.545 / 2000$.

$\mathrm{Na}$ representação gráfica dos trâmites do processo (Figura 5.18) pode ser visualizada a atuação dos diferentes agentes envolvidos e o tempo que cada agente foi demandado no processo de licenciamento ambiental da UTE Carioba II. 


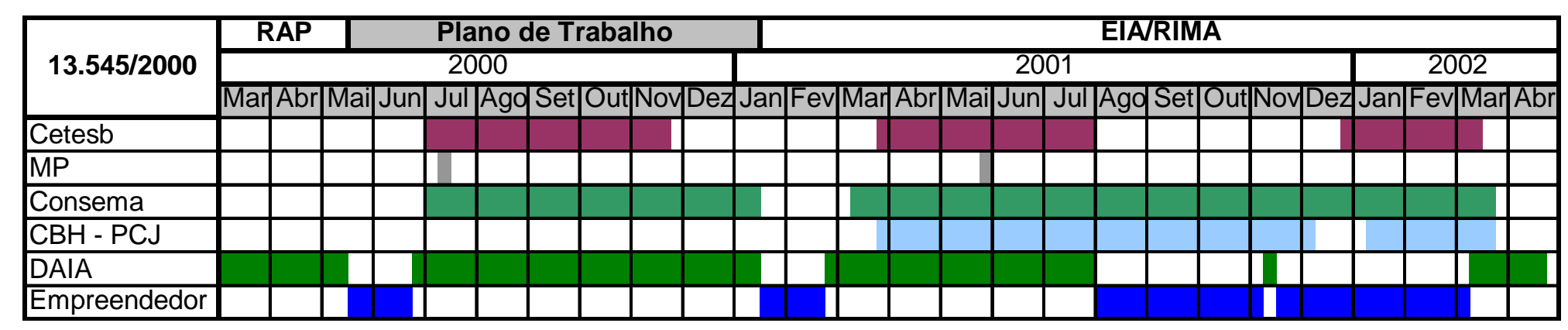

Figura 5.18. Representação da tramitação do processo de licenciamento ambiental da UTE Carioba II (SMA 13.545/2000). 


\section{Fatores qualitativos que podem ter interferido no tempo de tramitação do processo:}

No início do processo o Ministério Público solicitou Audiência Pública Preliminar para discussão do Plano de Trabalho encaminhado e, em momento posterior, após dado publicidade à entrega do EIA/RIMA, observa-se grande organização da sociedade civil, de órgãos ligados às prefeituras dos municípios de Americana, Guarujá, Limeira, Piracicaba e Paulínia e associações de profissionais que encaminharam ao Consema mais de 10 solicitações de Audiência Pública. A fim de atender tais solicitações, consta no processo estudado, a realização de 5 audiências públicas.

O Comitê de Bacia Hidrográfica dos rios Piracicaba, Capivari e Jundiaí participou do processo desde a análise do Plano de Trabalho, em que, por meio de parecer aprovado pela Deliberação CBH-PCJ 100/01, encaminhou sugestões a serem contempladas no EIA e apontou no Plano de Trabalho apresentado lacunas e omissões no tocante aos impactos e às medidas mitigadoras e compensatórias.

Com relação ao EIA apresentado, no que se refere à determinação dos potenciais impactos ambientais decorrentes das fases de planejamento, implantação e operação da usina, pode-se observar que este se restringiu a apresentar em tópicos os aspectos ambientais, que, segundo Sánchez (2006), são as atividades decorrentes de cada fase do empreendimento, como "Impacto da Movimentação de Solo e Rocha sobre a Qualidade das Águas". Sánchez (2006) afirma que esse erro básico ocorre freqüentemente nos estudos de impacto e que tal erro conceitual compromete a qualidade do estudo.

Pode ser observada no estudo a descrição dos aspectos ambientais decorrentes da implantação e operação do tramo do gasoduto, também como impacto ambiental, sendo que este não configurava ser objeto do processo de licenciamento.

Quanto ao estudo de alternativas locacionais apresentado no EIA, não foi considerado, dentre os parâmetros inicialmente selecionados, qualquer critério que pudesse conferir ao empreendimento maior viabilidade ambiental, como proximidade aos centros urbanos, condições atmosféricas do local, ou ainda, as interferências aos diversos usos dos recursos hídricos. 
Inicialmente, foram analisadas 7 alternativas locacionais, a saber: Americana (A); Viracopos/Campinas (B); Dois Córregos/Santa Maria da Serra (C); Araraquara (D); Bebedouro (E); Ibitinga (F) e Lins (G), de acordo com os seguintes parâmetros:

1) Proximidade das fontes de suprimento de combustível;

2) Proximidade dos principais centros de cargas;

3) Facilidade de conexão com a rede elétrica do sistema interligado;

4) Disponibilidade hídrica;

5) Disponibilidade de infra-estrutura de transporte para acesso e construção, e

6) Disponibilidade de área para implantação do projeto.

A partir destas avaliações técnico/econômicas, que resultaram na indicação de Americana para implantação da usina, foi feita uma análise quali-quantitativa, com atribuição de pesos, para avaliar os aspectos ambientais das alternativas propostas nos contextos sem o empreendimento, e com a inserção do empreendimento e das medidas de mitigação propostas, representadas, respectivamente, pela Tabela 5.9 e Tabela 5.10.

Para as análises feitas, quer seja considerando-se o local sem ou com o empreendimento, as notas foram dadas seguindo o princípio de que quanto melhor a qualidade do aspecto ambiental maior nota que deveria ser dada.

De acordo com os resultados foi apresentado que, para a alternativa locacional A (Americana) a condição do local com o empreendimento é ambientalmente mais favorável do que sem o empreendimento, ou ainda, que os aspectos ambientais água e flora seriam consideravelmente beneficiados com a implantação do empreendimento e ainda que, mesmo com a reconhecida emissão de efluentes gasosos, típica desta tipologia de empreendimento, o aspecto ar não sofreria alterações em relação à condição sem o empreendimento.

É possível concluir que o estudo não retrata com veracidade as alterações que a inserção do empreendimento poderia acarretar sobre as áreas de influência e que apresenta claras deficiências e fortes tendências quanto à escolha do município de Americana para a implantação do empreendimento, notadamente comprovado pelo Parecer Técnico CPRN/DAIA/115/2002 (SMA, 2000b) em sua pág. 3:

[...] as restrições ambientais da região, eventualmente subestimadas na avaliação locacional, impuseram custo econômico adicional ao 
projeto como, por exemplo, a substituição das torres de resfriamento por condensadores a ar e a redução da potência energética pleiteada (de $1.200 \mathrm{MW}$ para $945 \mathrm{MW}$ ).

Tabela 5.9. Análise das alternativas locacionais sem a implantação da UTE Carioba II.

\begin{tabular}{|l|c|c|c|c|c|c|c|c|}
\hline \multirow{2}{*}{ Aspecto Ambiental } & \multirow{2}{*}{ Peso } & \multicolumn{7}{|c|}{ Alternativas Locacionais } \\
\cline { 3 - 9 } & & A & B & C & D & E & F & G \\
\hline Ar & 10 & 50 & 10 & 100 & 100 & 100 & 100 & 100 \\
\hline Água & 10 & 10 & 10 & 50 & 50 & 50 & 100 & 100 \\
\hline Uso e ocupação do solo & 5 & 50 & 25 & 25 & 25 & 25 & 25 & 25 \\
\hline Flora & 5 & 25 & 50 & 25 & 25 & 25 & 25 & 25 \\
\hline Fauna & 5 & 50 & 50 & 25 & 25 & 25 & 25 & 25 \\
\hline Socioeconomia & 5 & 50 & 50 & 50 & 50 & 50 & 50 & 50 \\
\hline Somatório & & $\mathbf{2 3 5}$ & $\mathbf{1 9 5}$ & $\mathbf{2 7 5}$ & $\mathbf{2 7 5}$ & $\mathbf{2 7 5}$ & $\mathbf{3 2 5}$ & $\mathbf{3 2 5}$ \\
\hline
\end{tabular}

Tabela 5.10. Análise das alternativas locacionais com a implantação da UTE Carioba II.

\begin{tabular}{|l|c|c|c|c|c|c|c|c|}
\hline \multirow{2}{*}{ Aspecto Ambiental } & \multirow{2}{*}{ Peso } & \multicolumn{7}{|c|}{ Alternativas Locacionais } \\
\cline { 3 - 9 } & & A & B & C & D & E & F & G \\
\hline Ar & 10 & 50 & 10 & 10 & 10 & 10 & 10 & 10 \\
\hline Água & 10 & 100 & 10 & 10 & 10 & 10 & 10 & 10 \\
\hline Uso e ocupação do solo & 5 & 25 & 25 & 5 & 5 & 5 & 5 & 5 \\
\hline Flora & 5 & 50 & 50 & 50 & 50 & 50 & 50 & 50 \\
\hline Fauna & 5 & 50 & 50 & 50 & 50 & 50 & 50 & 50 \\
\hline Socioeconomia & 5 & 50 & 50 & 50 & 50 & 50 & 50 & 50 \\
\hline Somatório & & $\mathbf{3 2 5}$ & $\mathbf{1 9 5}$ & $\mathbf{1 7 5}$ & $\mathbf{1 7 5}$ & $\mathbf{1 7 5}$ & $\mathbf{1 7 5}$ & $\mathbf{1 7 5}$ \\
\hline
\end{tabular}

Cabe destacar também que durante o processo foram solicitadas 12 vezes informações complementares, uma vez que os órgãos responsáveis pela análise de viabilidade ambiental do empreendimento entenderam que havia deficiências no estudo apresentado. Também o alto número de condicionantes constantes na licença prévia expedida, com um baixo número de impactos ambientais identificados, podem indicar deficiências no estudo, quer seja na falta de um detalhamento no diagnóstico ambiental que ocasionaria subestimação dos impactos ambientais, quer seja na própria identificação dos impactos ou ainda nas medidas e programas propostos que não cumpriram a função de minimizar ou mitigar os potenciais impactos decorrentes. 


\title{
5.2.5 UTE Araraquara
}

O processo de licenciamento ambiental da UTE Araraquara iniciou-se em 2001, quando foi protocolizado o RAP e a solicitação de LP ao empreendimento sob responsabilidade da Energest S.A..

Assuntos externos ao processo de licenciamento em questão levaram o grupo português (Energest S.A.) a desistir do investimento em maio de 2003. A decisão foi justificada por questões ligadas às indefinições no modelo do setor elétrico, alto custo do gás natural e dificuldades ambientais, todos alinhados à política "conservadora" do grupo.

De acordo com o Eduardo Bernini, presidente da empresa Energest:

\begin{abstract}
Mesmo antes de os problemas conjunturais - sobra de energia e o preço do gás - começarem a desestimular os investimentos em termelétricas, o grupo já vinha enfrentando dificuldades para iniciar a obra em Araraquara. Com autorização da Aneel para a construção da usina desde 2000, o órgão ambiental ainda não havia emitido nenhuma das licenças ambientais necessárias para construir e colocar a usina em operação (CARVALHO, 2003).
\end{abstract}

É importante destacar que o pedido de licença ambiental prévia foi solicitado junto ao DAIA somente em 2001 e, pelo que se pode observar na tramitação do processo (Figura 5.22) os estudos ambientais, quer seja o RAP quer seja o EIA, apresentaram deficiências de informações que justificaram a solicitação de reelaboração de ambos. Enquanto então se aguardava a protocolização dos estudos solicitados foi cancelada a análise pelos órgãos envolvidos, a saber, DAIA, Cetesb, Consema e Comitê de Bacias Hidrográficas dos rios Tietê e Jacaré - CBH-TJ.

Durante o processo SMA 13.506/2001, sabe-se que foram solicitadas algumas informações complementares no período entre nov/2002 e fev/2003, mas devido à inexistência de documentos no processo consultado junto ao DAIA que comprovem tal data de solicitação optou-se por deixar este período hachurado, representado na Figura 5.22. Em 14/04/2003, a pedido do próprio empreendedor, foi cancelada a análise e este processo foi então arquivado. 
Em 2003, com nova solicitação de LP ao empreendimento UTE Araraquara, agora sob responsabilidade da ARS Energia Ltda., foi iniciado o processo SMA 13.734/2003, dando-se continuidade ao processo anterior a partir da fase de Plano de Trabalho. Portanto, nesta análise será considerada a fase de RAP do processo SMA 13.506/2001 e todos os trâmites do processo SMA 13.734/2003.

As principais características do empreendimento, de acordo com o processo SMA 13.734/2003, seguem descritas pelo Quadro 5.8.

\begin{tabular}{|c|c|}
\hline Empreendimento & Usina Termelétrica Araraquara \\
\hline Números dos processos no DAIA & $\begin{array}{l}\text { SMA 13.506/2001 (SMA, 2001) e } \\
\text { SMA 13.734/2003 (SMA, 2003) }\end{array}$ \\
\hline Município & Araraquara \\
\hline Empreendedor & ARS Energia \\
\hline Local de implantação & $\begin{array}{l}\text { Área de } 15 \text { ha, na Fazenda Palmeiras, } \\
\text { zona rural de Araraquara, conforme } \\
\text { Figura 5.19. }\end{array}$ \\
\hline Coordenadas & $21^{\circ} 53^{\prime} 5.09^{\prime \prime S} ; 4^{\circ} 16^{\prime} 57.86^{\prime \prime W}$ \\
\hline Potência Instalada & $512 \mathrm{MW}$ \\
\hline Combustível & 2,3 milhões $\mathrm{m}^{3} / \mathrm{d}$ de gás natural \\
\hline Investimento & US\$ 450 milhões \\
\hline Rio para captação & Rio Jacaré Guaçu \\
\hline Intervenção em Unidade de Conservação & Não \\
\hline Restrições Ambientais destacadas & De acordo com o EIA, não existiam. \\
\hline Previsão para ser instalada & Após concessão de LI \\
\hline Licença Ambiental Prévia & LP no 00807 de 08/03/2005 \\
\hline Observações & $\begin{array}{l}\text { - Inscrita no PPT (Usina a gás natural } \\
\text { em ciclo combinado, conforme Portaria } \\
\text { 43/2000); } \\
\text { - Contemplado pela Medida Provisória } \\
\text { no 2147/2001. }\end{array}$ \\
\hline
\end{tabular}

Quadro 5.8. Principais características da UTE Araraquara. 


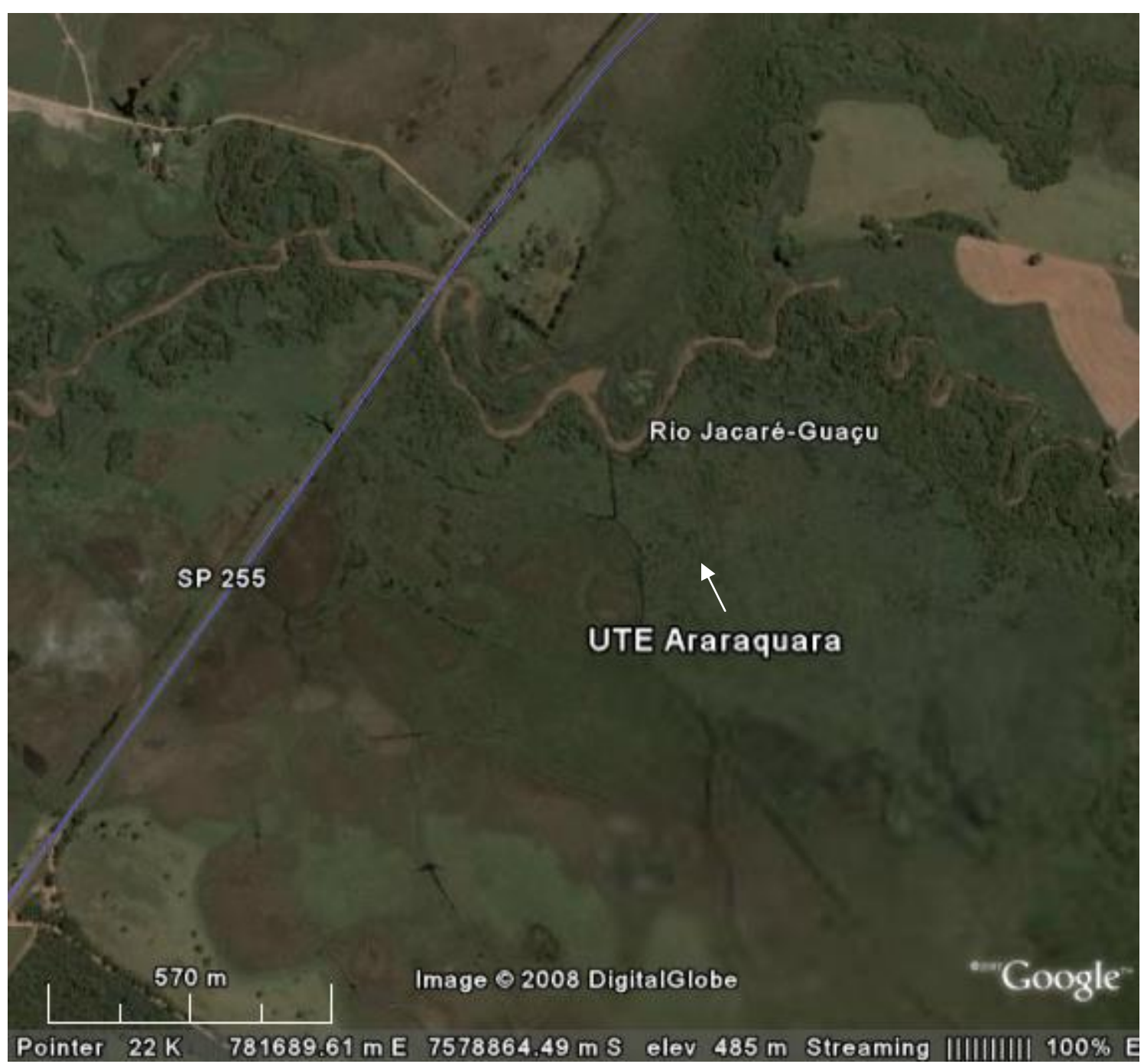

Figura 5.19. Localização proposta para implantação da UTE Araraquara (extraído de Google Earth).

A Tabela 5.11 representa a caracterização dos processos de licenciamento ambiental da UTE Araraquara junto ao DAIA, frente aos fatores selecionados. Ressalta-se que, para a quantificação dos fatores selecionados (Tabela 5.11) e análise dos tempos de tramitação (Tabela 5.12) foi considerada a fase de RAP do processo SMA 13.506/2001, incluindo-se o tempo de elaboração do Plano de Trabalho, e todos os trâmites ocorridos durante o processo SMA 13.734/2003, para que o processo se configurasse semelhante aos demais estudados, ou seja, desde a apresentação do RAP até a concessão da LP.

No tempo de tramitação sob responsabilidade do empreendedor (Tabela $5.12 \mathrm{e}$ Figura 5.20), ou seja, $40,6 \%$ do tempo total de tramitação, encontra-se incluído o tempo utilizado para a reelaboração do RAP, solicitado pelo DAIA no processo em 
2001. Também encontra-se incluído o tempo em que o empreendedor providenciava, durante o processo SMA 13.734/2003, as informações complementares solicitadas pelos diversos órgãos envolvidos no processo, a saber, reelaboração do Programa de Compensação Ambiental, informações referentes aos aspectos de efluentes líquidos, resíduos sólidos, emissões atmosféricas, ruídos e vibrações, e ainda as informações requisitadas pelo DAIA.

Tabela 5.11. Caracterização dos processos SMA 13.506/2001 e SMA 13.734/2003 frente aos fatores selecionados.

\begin{tabular}{|l|c|}
\hline \multicolumn{1}{|c|}{ Fatores selecionados } & Quantificação \\
\hline Número de solicitação de informações complementares & 5 \\
\hline Número de impactos ambientais identificados no EIA/RIMA & 28 \\
\hline Número de condicionantes constantes na LP expedida & 42 \\
\hline
\end{tabular}

Tabela 5.12. Análise dos tempos de tramitação dos processos SMA 13.506/2001 e SMA $13.734 / 2003$

\begin{tabular}{|l|c|}
\hline \multicolumn{1}{|c|}{ Tempos de tramitação } & Quantificação \\
\hline Tempo total de tramitação do processo até a obtenção da LP & 672 dias \\
\hline Tempo total de tramitação que depende do empreendedor & 273 dias \\
\hline Tempo total de tramitação que independe de ação do empreendedor & 399 dias \\
\hline
\end{tabular}

Neste processo pode ser observado por meio da Figura 5.21 que, para análise de viabilidade ambiental do empreendimento, houve envolvimento de agentes até então não demandados, em especial, observa-se a solicitação de manifestação do DEPRN nos aspectos relacionados à supressão de vegetação, intervenção em APP e fauna silvestre e a participação no processo do Conselho Municipal de Defesa do Meio Ambiente (Condema). O Comitê de Bacia envolveu-se no processo com a questão relacionada à captação de água e outorga de direito de uso.

O tempo total de análise do DAIA (399 dias) inclui o tempo em que este Departamento aguardava as manifestações solicitadas aos agentes envolvidos, em especial no que se refere à LP concedida somente após todos os agentes demandados encaminharam suas manifestações. Observa-se na Figura 5.23 que, mesmo quando o processo estava sob responsabilidade do empreendedor, os agentes que entenderam que as informações estavam satisfatórias deram continuidade na análise. 


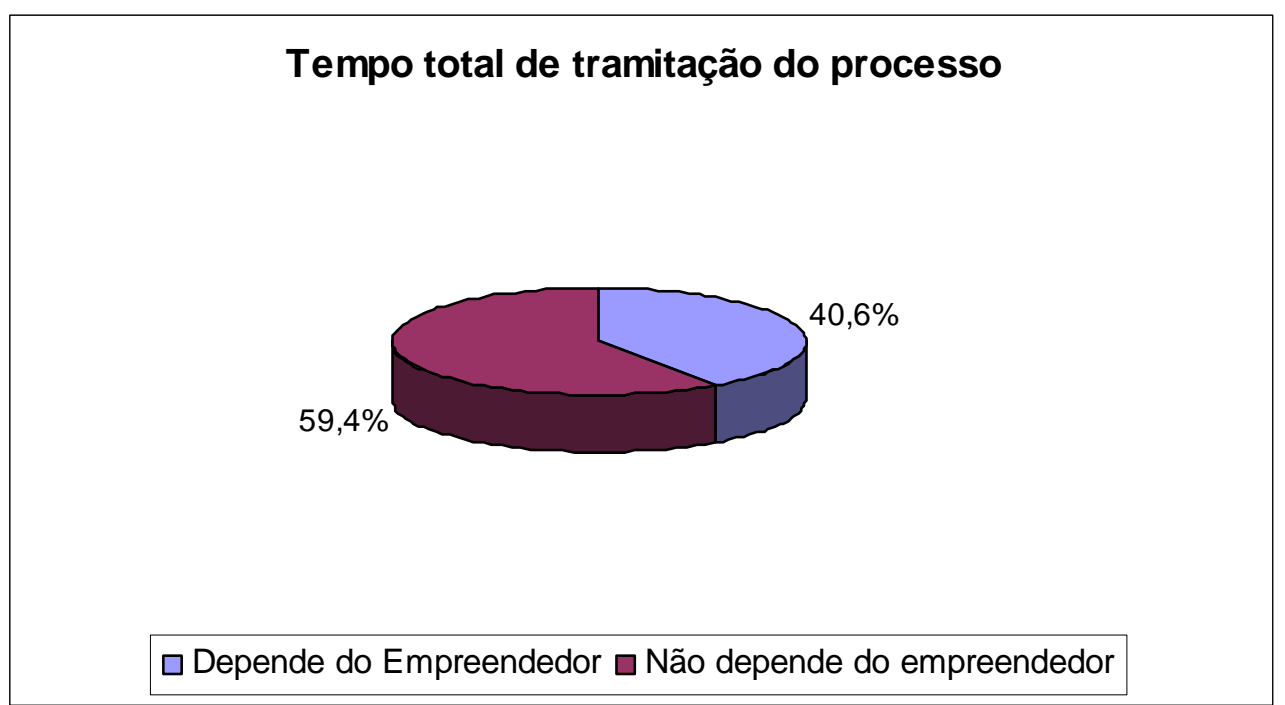

Figura 5.20. Tempo total de tramitação do processo de licenciamento ambiental da UTE Araraquara.

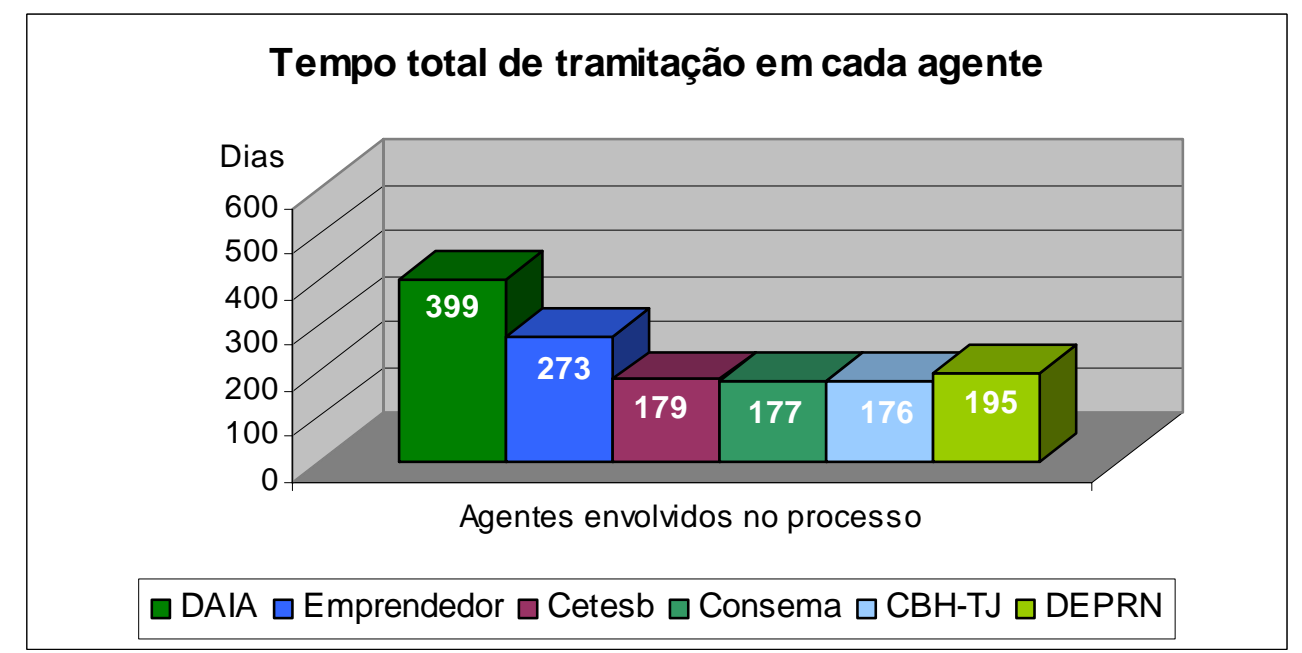

Figura 5.21. Tempo total de tramitação em cada agente envolvido no processo. 


\begin{tabular}{|c|c|c|c|c|c|c|c|c|c|c|c|c|c|c|c|c|c|c|c|c|c|c|}
\hline \multirow{3}{*}{$13.506 / 2001$} & \multicolumn{7}{|c|}{ RAP } & Plano & & \multicolumn{13}{|c|}{ EIA/RIMA } \\
\hline & \multicolumn{10}{|c|}{2001} & \multicolumn{9}{|c|}{2002} & \multicolumn{3}{|c|}{2003} \\
\hline & Jan & $|F e v| r$ & Mar & Abr & Mai & i Jun & \begin{tabular}{|l|} 
Jul \\
\end{tabular} & \begin{tabular}{|l|l|} 
Ago & Set \\
\end{tabular} & Out & Nov|Dez & Jan & Fev|Mar & Abr & Mai & Jun & \begin{tabular}{|l|l|} 
Jul & Ago \\
\end{tabular} & Set & Out/Nov'L & |Dez & Jan & & Mar $\mid \mathrm{Abr}$ \\
\hline Cetesb & & & & & & & & & & & & & & & & & & & & & 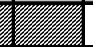 & \\
\hline $\mathrm{MP}$ & & & & & & & & & & & & & & & & & & & & & 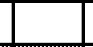 & \\
\hline Consema & & & & & & & & & & & & & & & & & & & & & & \\
\hline $\mathrm{CBH}-\mathrm{TJ}$ & & & & & & & & & & & & & & & & & & & & & & \\
\hline DAIA & & & & & & & & & & & & & & & & & & & & & & \\
\hline Empreendedor & & & & & & & & & & & & & & & & & & & & & & \\
\hline
\end{tabular}

Figura 5.22. Representação da tramitação do processo de licenciamento ambiental da UTE Araraquara (SMA 13.506/2001).

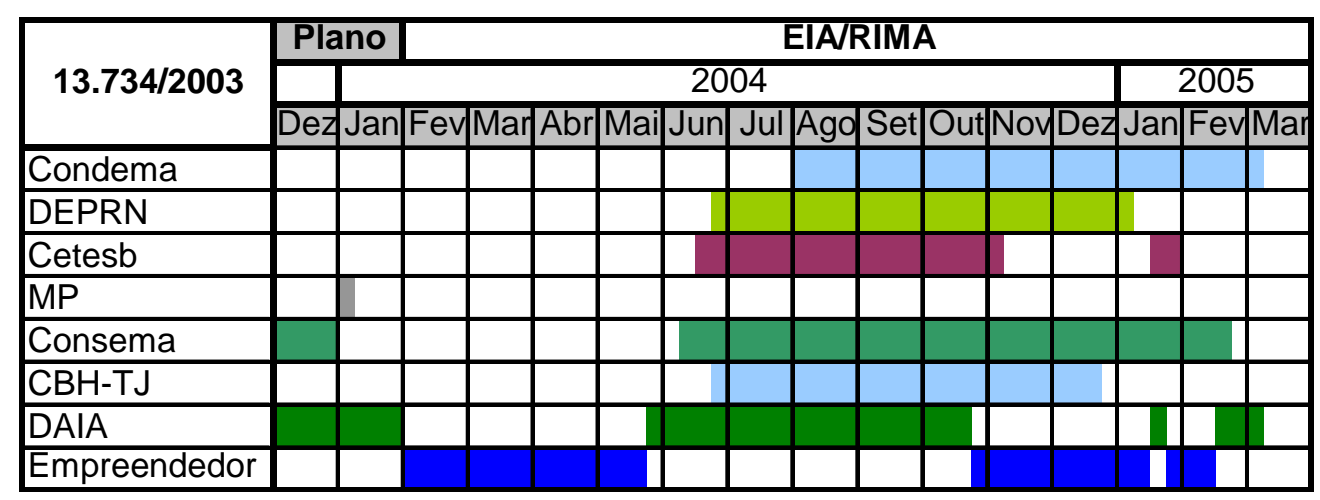

Figura 5.23. Representação da tramitação do processo SMA 13.734/2003. 


\section{Fatores qualitativos que podem ter interferido no tempo de tramitação do processo:}

Segundo o estudo locacional apresentado, inicialmente, tendo como base informações sobre a rota do Gasoduto Bolívia - Brasil, foram pré-selecionadas nove alternativas, as quais foram identificadas e apresentadas em carta gráfica. As alternativas situavam-se nos seguintes rios:

- Rio Jacaré-Guaçu alternativas 1, 1A, 2, 2A, e 3

- Rio Corumbataí alternativa 4

- Rio Capivari. alternativa 5

- Rio Tietê alternativa 6

- Rio Mogi-Guaçu alternativa 7

Estas alternativas foram analisadas frente aos seguintes aspectos ambientais:

- Intervenção em Unidades de Conservação;

- Existência de pontos notáveis (locais susceptíveis à erosões; travessias; principais cruzamentos com rodovias, ferrovias e linhas de transmissão);

- Caracterização do uso atual do solo e identificação de áreas para proteção ambiental (fragmentos florestais; áreas de silvicultura; agricultura e assentamento populacional);

- Disponibilidade de água e gás e facilidade de acesso à malha rodoviária;

- Possibilidade de ligação à rede básica do sistema de transmissão;

- Identificação de restrições ambientais.

Das alternativas analisadas foram descartadas as alternativas 1 e $1 \mathrm{~A}$ por serem consideradas áreas de proteção ambiental; a alternativa 3 por falta de acesso adequado e as alternativas 4 e 5 por carência de água, enquanto que as demais foram quantificadas e então comparadas entre si, de acordo com a Tabela 5.13, considerando:
a) disponibilidade hídrica;
b) distância da rede de distribuição de gás natural;
c) distância da linha de transmissão;
d) condições físicas do terreno para implantação do empreendimento;
e) restrições impostas quanto ao uso do solo;
f) comprimento de ramal para ligação ao city-gate mais próximo. 
O valor 1 foi atribuído para situações consideradas "insatisfatórias", o valor 2 para as "satisfatórias" e o valor 3 para as condições consideradas "boas".

Tabela 5.13. Análise comparativa entre as alternativas locacionais propostas.

\begin{tabular}{cccccccc}
\hline Alternativa & a) & b) & c) & d) & e) & f) & Total \\
\hline $\mathbf{2}$ & 3 & 3 & 1 & 3 & 3 & $1(10 \mathrm{~km})$ & 14 \\
$\mathbf{2 A}$ & 3 & 3 & 3 & 3 & 3 & $3(6 \mathrm{~km})$ & 18 \\
$\mathbf{7}$ & 3 & 3 & 1 & 2 & 3 & 3 & 15 \\
$\mathbf{6}$ & 3 & 3 & 3 & 3 & 1 & $1(8 \mathrm{~km})$ & 14 \\
\hline
\end{tabular}

Portanto, a localização proposta para implantação da usina, conforme Figura 5.19, constituía-se por uma área de 15 ha, localizada dentro da Fazenda Palmeiras, zona rural de Araraquara, onde havia predominância de pastagem e cana-de-açúcar e ficava a aproximadamente 12 e $22 \mathrm{kms}$ da área urbana dos municípios de Araraquara e Gavião Peixoto, respectivamente.

Durante a análise do estudo apresentado no decorrer da tramitação do processo, foi observado que algumas questões pertinentes ao projeto da usina não foram apresentadas de forma clara e refletiram diretamente no andamento do processo, como foi o caso da definição da vazão de água a ser captada no rio JacaréGuaçu para a operação da usina e conseqüente outorga de direito de uso. Apresentando uma diferença considerável, a vazão necessária para captação era de $700 \mathrm{~m}^{3} / \mathrm{h}$, enquanto que a outorga solicitada e concedida pelo DAEE autorizava a captação de $1800 \mathrm{~m}^{3} / \mathrm{h}$.

É importante destacar que os aspectos ambientais considerados no estudo locacional e na escolha do local proposto para a implantação da usina térmica, a saber, proximidade a centros urbanos, intervenção em Unidades de Conservação, áreas frágeis susceptíveis à erosão, áreas de proteção ambiental e restrições ambientais, podem ter influenciado na tramitação do processo de licenciamento ambiental, por conferirem maior viabilidade ambiental ao empreendimento. 


\subsection{Análise comparativa entre os processos/empreendimentos consultados}

Embora o período pesquisado tenha sido entre os anos de 1998 e 2007, não há registros no DAIA de processos de licenciamento ambiental de usinas termelétricas a gás natural com potência instalada superior a $10 \mathrm{MW}$ que tenham tramitado após 2003 e que tenham resultado na emissão da LP. Assim, apesar do número de processos analisados ser pequeno (6 processos de 5 UTEs, conforme se observa no Quadro 5.9), estes representam a totalidade dos casos segundo o recorte adotado, e não uma amostra. Na Tabela 5.14 são apresentados os resultados das análises dos processos.

\begin{tabular}{lcc}
\hline \multicolumn{1}{c}{ Usina Termelétrica } & Sigla & $\begin{array}{c}\text { Processo } \\
\text { SMA }\end{array}$ \\
\hline Central de Cogeração da Baixada Santista & CCBS & $13.698 / 1998$ \\
\hline Santa Branca & SB & $13.696 / 1999$ \\
Duke Energy 1 & DK1 & $13.629 / 2000$ \\
Carioba II & CAll & $13.545 / 2000$ \\
Araraquara & ARA & $13.506 / 2001$ \\
\hline
\end{tabular}

Quadro 5.9. Identificação das UTEs a gás natural, com potência instalada superior a $10 \mathrm{MW}$, que obtiveram LP no Estado de São Paulo e respectivo processo tramitado no âmbito do DAIA.

Tabela 5.14. Resultados das análises dos processos consultados.

\begin{tabular}{lccccc}
\hline & \multicolumn{5}{c}{ Usina Termelétrica } \\
\hline \multicolumn{1}{c}{ Fatores } & CCBS & SB & DK1 & CAll & ARA \\
\hline $\begin{array}{l}\text { Tempo total de tramitação (dias) } \\
\text { Número de solicitações de informações }\end{array}$ & 877 & 992 & 493 & 771 & 672 \\
$\begin{array}{l}\text { complementares feitas pelos órgãos ambientais } \\
\text { ao empreendedor }\end{array}$ & 5 & 2 & 2 & 12 & 5 \\
$\begin{array}{l}\text { Número de impactos ambientais identificados no } \\
\text { ElA }\end{array}$ & 21 & 38 & 33 & 29 & 28 \\
$\begin{array}{l}\text { Número de condicionantes exigidas por meio da } \\
\text { LP expedida }\end{array}$ & 16 & 67 & 40 & 75 & 42 \\
\hline
\end{tabular}

Desde que o EIA apresentado tenha sido elaborado de forma satisfatória, ou seja, sem deficiências, como as apontadas por MPF (2004), pode-se supor que quanto maior o número de impactos identificados, maiores são as restrições ambientais do local escolhido para a instalação do empreendimento proposto. Decorrente dessa suposição, espera-se que, quanto maior o número de impactos ambientais negativos identificados, tanto maior deverá ser o número de medidas mitigadoras propostas e, 
conseqüentemente, maior deve ser o número de condicionantes previstas na LP emitida. De fato, observando a Figura 5.24, pode-se verificar uma forte relação entre o número de impactos identificados no EIA apresentado e o número de condicionantes constantes na licença expedida. Pela análise de regressão linear, nota-se que o valor de $\mathrm{R}^{2}$ (coeficiente de correlação que expressa o quanto a reta se ajusta aos valores representados ou, ainda, o quão preciso será um valor obtido por meio de sua expressão) assume valor igual a 0,89, confirmando, portanto, sua significativa representatividade.

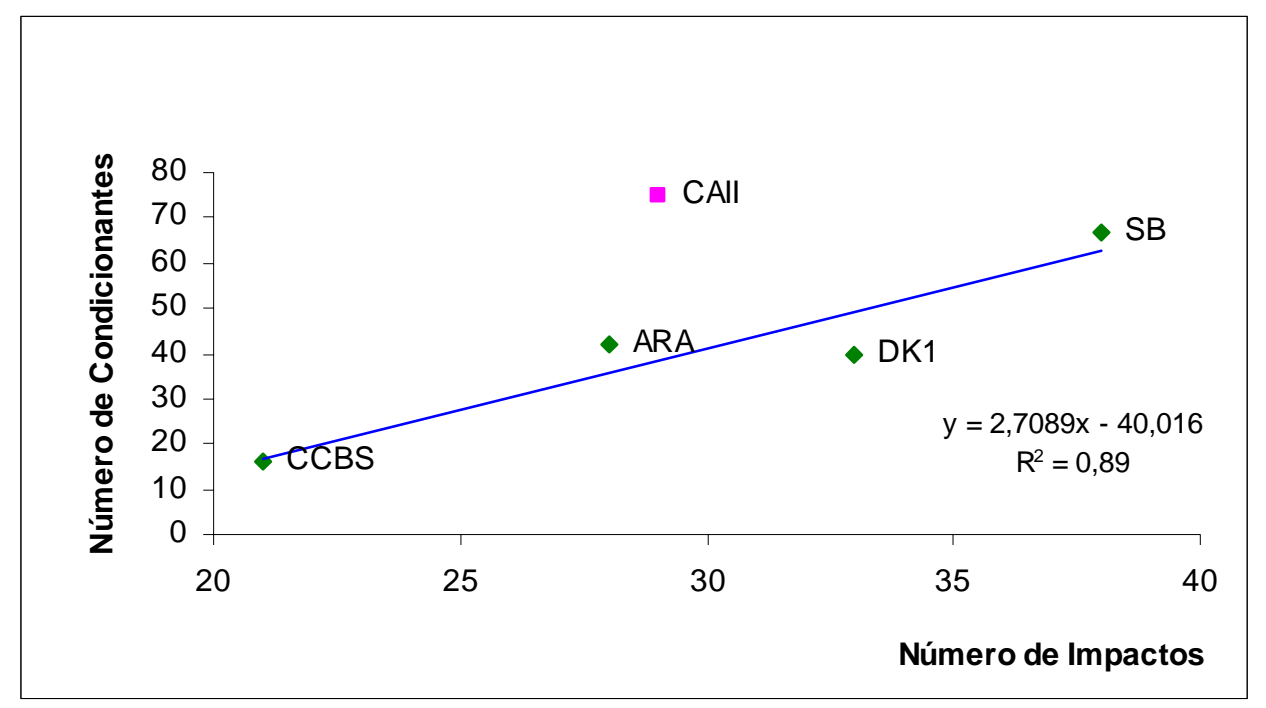

Figura 5.24. Análise da relação entre o número de impactos ambientais identificados no EIA do empreendimento e o número de condicionantes constantes na LP.

Deve ser mencionado, no entanto, que tal relação somente é observada pois foi descartado na regressão linear o dado referente ao licenciamento ambiental da UTE Carioba II. A opção por descartar tal dado decorre da falta de proporcionalidade observada neste processo entre o número de impactos ambientais identificados no EIA daquele empreendimento (somente 29 potenciais impactos ambientais) e o número de condicionantes constantes na LP concedida (75 condicionantes).

Observa-se que, durante o processo de licenciamento prévio daquela usina, por 12 vezes foram solicitadas informações complementares (Tabela 5.14). Ademais, por meio do parecer aprovado pela Deliberação CBH-PCJ 100/01, o Comitê apontou a existência de lacunas e omissões no Plano de Trabalho no tocante aos impactos ambientais e às medidas mitigadoras e compensatórias. Diante disto, é possível supor que o número de condicionantes exigidas na LP expedida justifica-se por grandes deficiências no EIA apresentado e/ou forte organização da sociedade civil em 
oposição à instalação do empreendimento e/ou inadequação do projeto ao local proposto.

Apesar de haver relação direta entre o número de impactos e o número de condicionantes, verifica-se que o número de impactos (Figura 5.25) ou o número de condicionantes (Figura 5.26) não apresentam relação com o tempo total de tramitação dos processos na fase de LP. Entretanto, o número de condicionantes pode afetar o tempo de tramitação da fase seguinte do processo, quando, para a obtenção da licença de instalação faz-se necessário o cumprimento das condicionantes constantes na LP emitida.

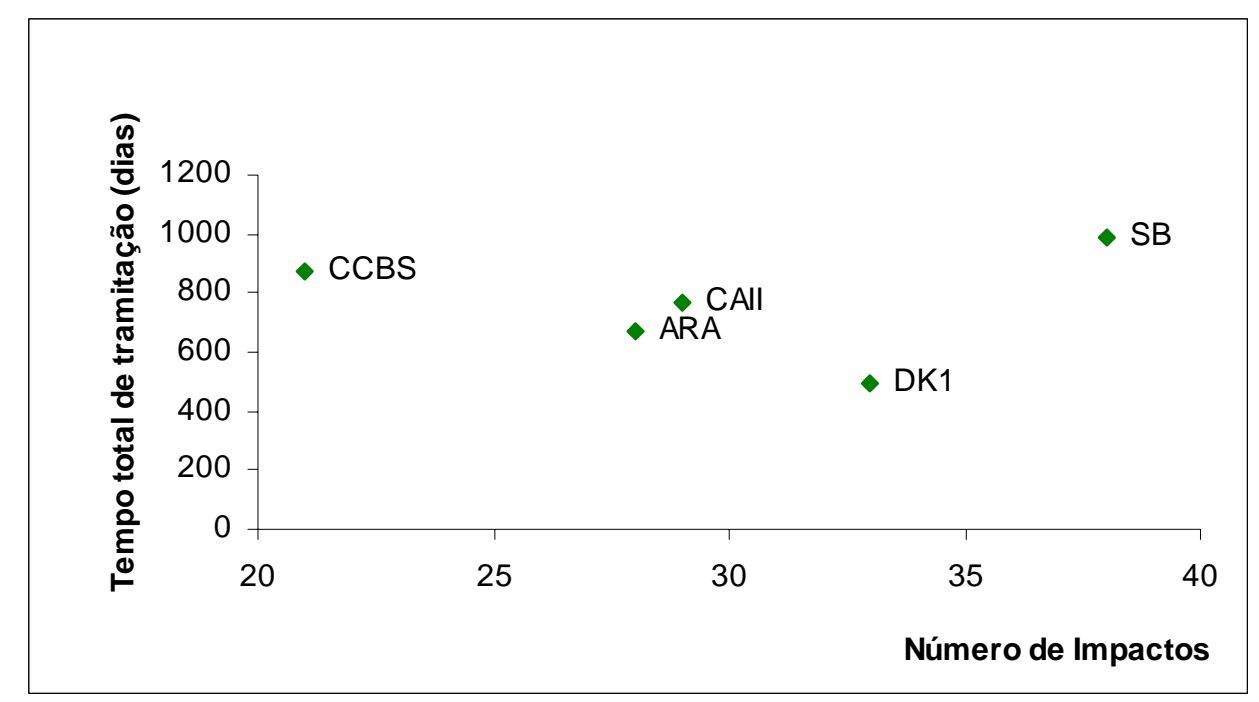

Figura 5.25. Análise da relação entre o número de impactos ambientais e o tempo total de tramitação do processo.

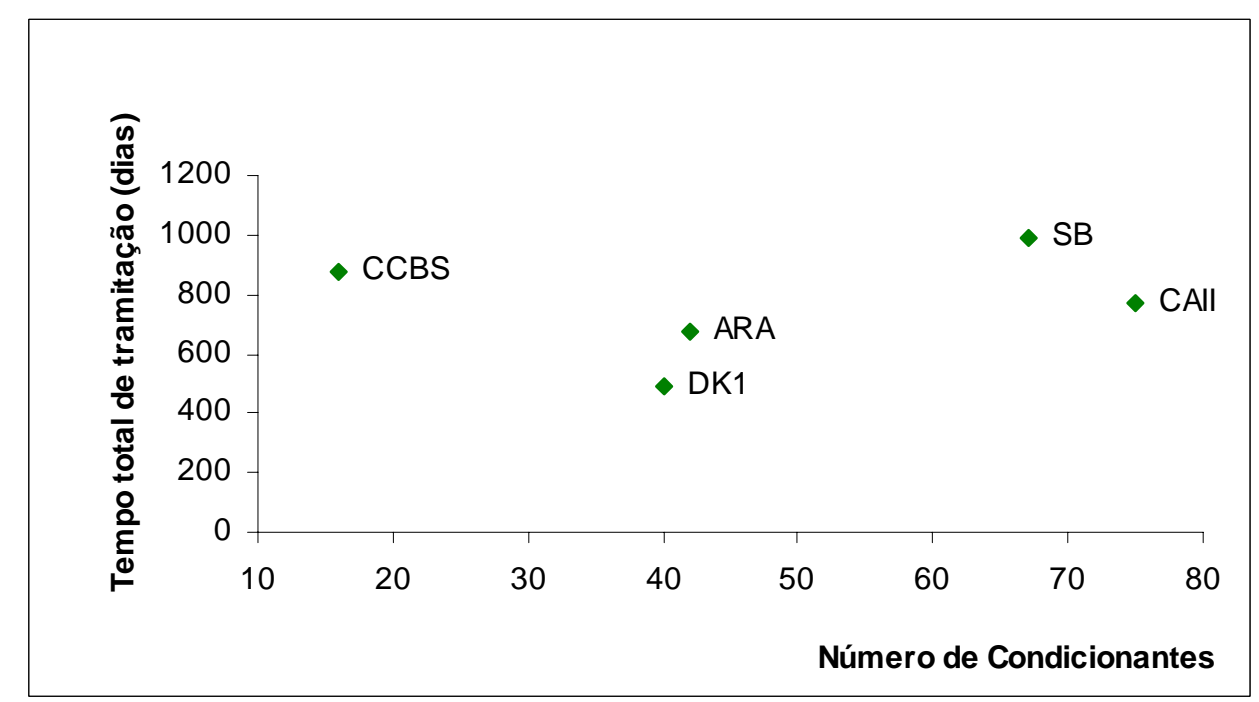

Figura 5.26. Análise da relação entre o número de condicionantes constantes na LP e o tempo total de tramitação do processo. 
É interessante notar que a tramitação do processo da UTE Duke Energy 1 ocorreu em menor tempo se comparado com as UTEs CCBS, Carioba II e Araraquara, apesar da primeira apresentar em seu EIA um número maior de impactos ambientais (33) do que as outras três. Esse resultado talvez possa ser explicado pela combinação entre uma escolha de alternativa locacional mais adequada e um estudo ambiental com menos deficiências, no caso da UTE Duke Energy 1. Vale lembrar que o local proposto para a instalação de Carioba II apresentava sérias restrições ambientais devido à baixa disponibilidade hídrica e a proximidade com áreas populosas (problemas com poluição atmosférica), enquanto que o local pretendido para a implantação da CCBS apresentava limitações em função da proximidade com Unidade de Conservação (Parque Estadual da Serra do Mar) e da saturação de poluentes, na época identificada no local. Seria esperado, nesses dois casos, que o número de impactos identificados nos estudos ambientais fosse maior. Em relação ao processo de licenciamento da UTE Araraquara o que difere ao da UTE Duke Energy 1 foi quanto ao número de solicitações de informações complementares, conseqüentemente o tempo de tramitação sob responsabilidade do empreendedor representou $40,6 \%$ do tempo total de tramitação deste processo.

Em relação à Figura 5.26, nota-se que as licenças que mais apresentaram condicionantes vinculadas foram as emitidas para as UTEs Carioba II e Santa Branca, possivelmente pelas restrições ambientais claramente impostas pelas alternativas locacionais escolhidas ou, ainda, devido à forte participação do Ministério Público e da sociedade civil organizada em ambos os casos.

Situação um tanto quanto contraditória, observada na Figura 5.26, é a quantidade de condicionantes observadas (apenas 16) na licença prévia emitida para a UTE CCBS que, conforme mencionado acima, seria instalada próxima ao Parque Estadual da Serra do Mar e em local, tido na época, como saturado por poluentes atmosféricos devido ao pólo industrial já instalado em Cubatão e à baixa taxa de dispersão atmosférica. Não se pode descartar, também, a possibilidade de fatores externos ao processo terem influenciado na tramitação. Fatores como a relação número de técnicos envolvidos na análise versus número de processos tramitando na mesma época, o rigor adotado pelos técnicos na análise do EIA ou, ainda, as possíveis pressões de interesse institucionais, políticos ou econômicos que não foram considerados nesta pesquisa. 
Verifica-se, pela análise da Figura 5.27, não haver relação direta também entre o número de solicitações de informações complementares feitas pelos órgãos ambientais aos empreendedores e o tempo total de tramitação dos processos.

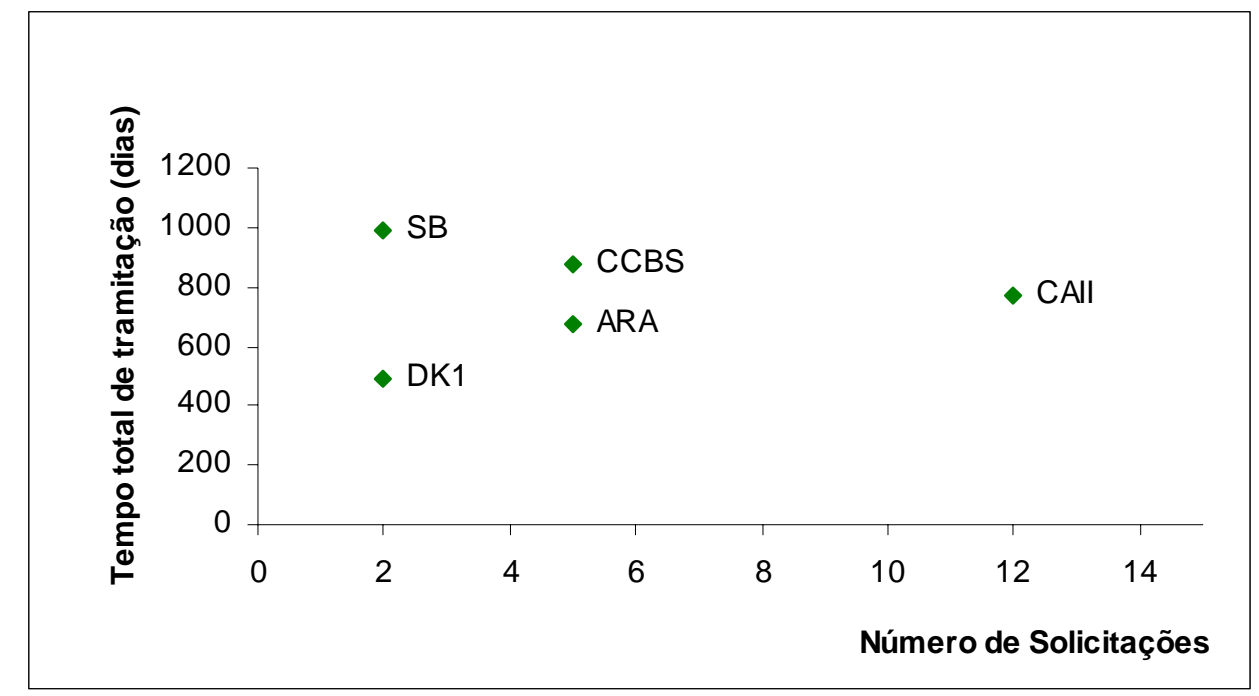

Figura 5.27. Análise da relação entre o número de solicitações de informações complementares feitas pelos órgãos ambientais ao empreendedor e o tempo total de tramitação do processo.

Destaca-se que os empreendimentos Duke Energy 1 e Santa Branca foram aqueles para os quais foram feitas menos solicitações de informações complementares e são justamente os que tiveram os processos com menor e maior tempo de tramitação total, respectivamente. Note-se que o processo da UTE Santa Branca teve um tempo de tramitação aproximadamente duas vezes maior do que o da UTE Duke Energy I.

Diante da constatação de que não existe uma relação entre número de impactos, número de condicionantes e número de solicitações de informações complementares com o tempo total de tramitação do processo, buscou-se verificar a existência de relação entre este tempo com a maior ou menor agilidade na resposta dos órgãos ambientais e do empreendedor.

Neste sentido, o tempo total de tramitação do processo foi subdividido em "tempo total de tramitação que depende do empreendedor" e "tempo total de tramitação que independe de ação do empreendedor".

O tempo total de tramitação que depende do empreendedor diz respeito ao tempo utilizado pelo empreendedor e sua equipe técnica para elaborar os estudos ambientais exigidos após o início do processo e responder as solicitações feitas pelos 
órgãos ambientais, portanto, corresponde ao tempo de tramitação sob sua responsabilidade. Já o tempo de tramitação que independe de ação do empreendedor corresponde ao tempo em que a tramitação do processo estava exclusivamente sob responsabilidade dos agentes envolvidos na análise de viabilidade ambiental do empreendimento, ou seja, quando o empreendedor não foi demandado a apresentar qualquer estudo obrigatório ou informação complementar. Os resultados dessa análise encontram-se representados na Tabela 5.15.

Tabela 5.15. Discriminação do tempo total de tramitação dos processos.

\begin{tabular}{|c|c|c|c|c|c|}
\hline & $\begin{array}{l}\text { Tempo total de } \\
\text { tramitação (dias) }\end{array}$ & & & & \\
\hline UTE & $\begin{array}{l}\text { Que depende do } \\
\text { empreendedor (a) }\end{array}$ & $\begin{array}{l}\text { Percentual } \\
(a /(a+b))\end{array}$ & $\begin{array}{l}\text { Que independe } \\
\text { de ação do } \\
\text { empreendedor } \\
\text { (b) }\end{array}$ & $\begin{array}{l}\text { Percentual } \\
(b /(a+b))\end{array}$ & $(a+b)$ \\
\hline CCBS & 281 & $32,04 \%$ & 596 & $67,96 \%$ & 877 \\
\hline $\mathrm{SB}^{\star}$ & 387 & $41,43 \%$ & 547 & $58,57 \%$ & 934 \\
\hline DK1 & 85 & $17,24 \%$ & 408 & $82,76 \%$ & 493 \\
\hline CAII & 271 & $35,15 \%$ & 500 & $64,85 \%$ & 771 \\
\hline ARA & 273 & $40,63 \%$ & 399 & $59,38 \%$ & 672 \\
\hline Média & 303 & & 490 & & \\
\hline
\end{tabular}

O tempo médio de tramitação do processo que independe do empreendedor é de 490 dias, tendo, portanto, uma variação de cerca de 6 meses, sendo o tempo mínimo de 1 ano 1 mês e 4 dias (UTE Araraquara) e o tempo máximo de 1 ano 7 meses e 17 dias (UTE CCBS).

O tempo médio que depende de ação do empreendedor corresponde a 303 dias, calculado excluindo-se o valor da UTE DK1 uma vez que caso fosse considerado o desvio padrão seria de 108,95, bem acima dos 56,17 quando durante o cálculo médio este valor é excluído. Os valores observados de tempo que depende de ação do empreendedor apresentaram uma variação de aproximadamente 10 meses, sendo os extremos dados pela UTE Duke Energy 1 (85 dias) e pela UTE Santa Branca (387 dias). Interessante reforçar que nos processos de Duke Energy 1 e Santa Branca foi feito o mesmo número de solicitações de informações complementares (duas em cada caso). 
Na Figura 5.28 observa-se que o tempo de tramitação que independe de ação do empreendedor e o tempo total de tramitação do processo não apresentam uma forte relação $\left(R^{2}=0,71\right)$. No entanto, a Figura 5.29 demonstra haver mais forte relação entre o tempo de tramitação do processo sob responsabilidade do empreendedor e o tempo total de tramitação do processo, com valor de $\mathrm{R}^{2}$ de 0,87 , aproximadamente.

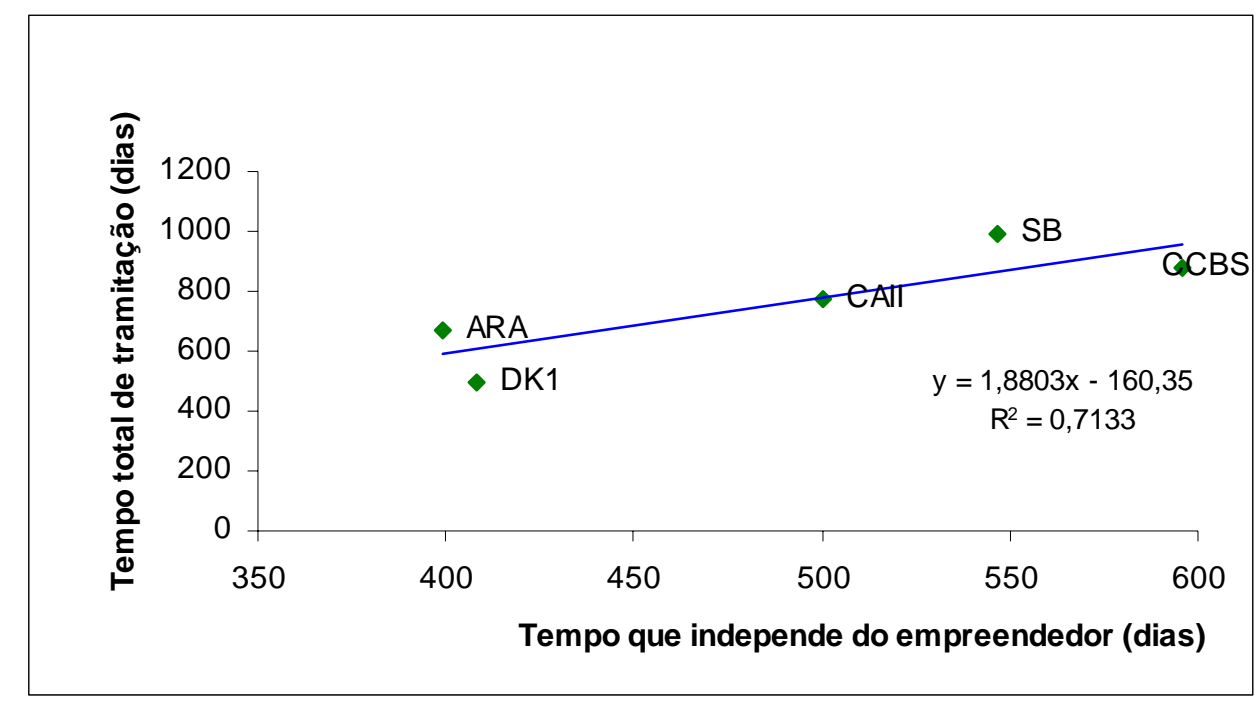

Figura 5.28. Relação entre o tempo que independe do empreendedor e o tempo total de tramitação do processo.

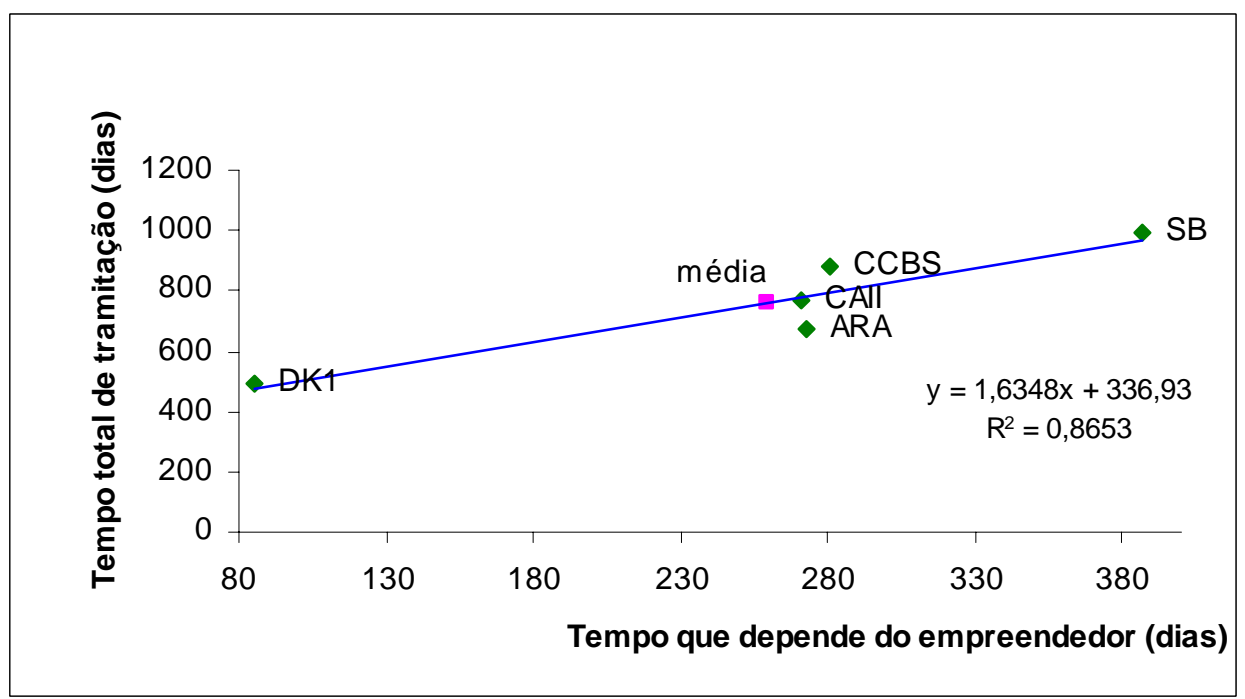

Figura 5.29. Relação entre o tempo total de tramitação que depende do empreendedor e o tempo total de tramitação do processo. 
Merece destaque o fato dos empreendimentos que apresentaram as alternativas locacionais mais restritivas (CCBS, Carioba II e Santa Branca) serem aqueles cujos processos ficaram por mais tempo sob a responsabilidade do empreendedor durante sua tramitação.

Diante disto, pode-se supor que quanto maior o tempo sob responsabilidade do empreendedor, seja no atendimento às complementações solicitadas ou na elaboração de estudos, a tendência é de que maior será o tempo de tramitação do processo. É importante mencionar que, para esta análise, não foi considerado o tempo de elaboração do RAP, por essa informação não constar nos processos consultados.

Pela análise comparativa entre o tempo de tramitação que independe do empreendedor em função do ano de início do processo (ano de solicitação da LP) observa-se que houve uma tendência de diminuição deste tempo com o passar dos anos (Figura 5.30), quer seja pelo aperfeiçoamento da equipe técnica e/ou pelo aumento no número de técnicos envolvidos, o que promoveria maior agilidade na análise. Entretanto, a adoção de parâmetros menos criteriosos na análise ou pressões advindas de interesses institucionais, políticos ou econômicos também podem ter influência nos tempos de tramitação dos processos.

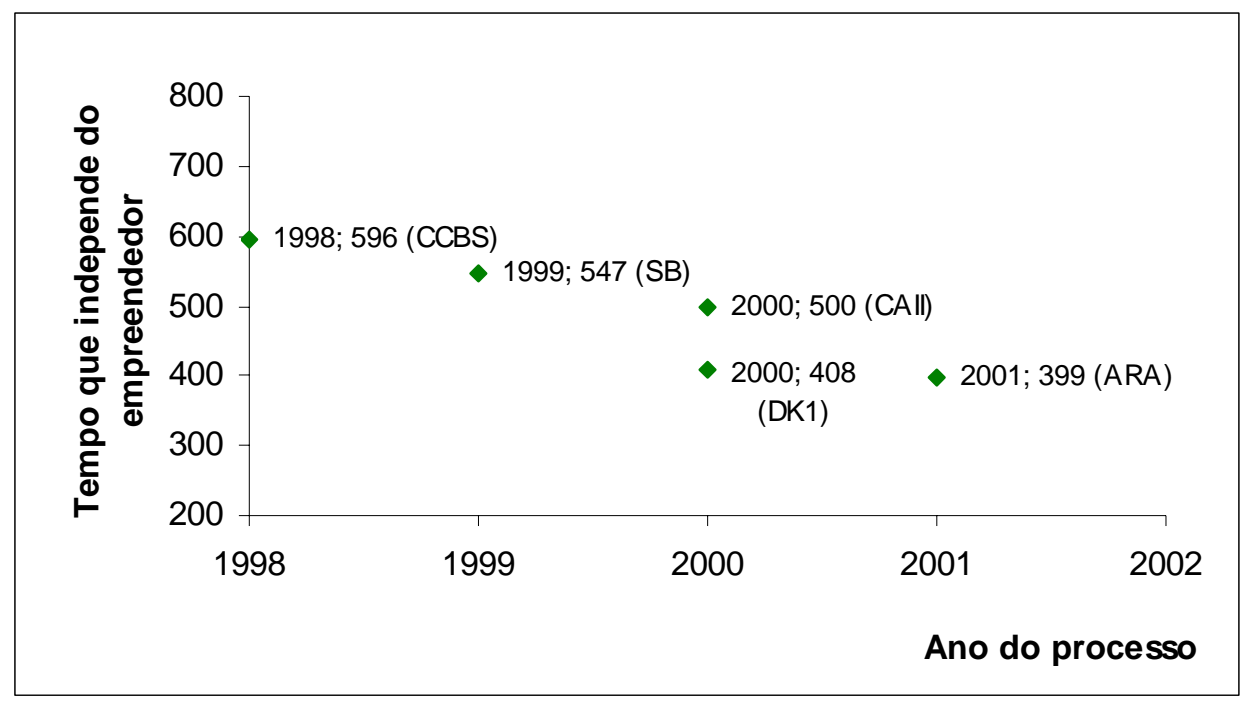

Figura 5.30. Tempo de tramitação que independe do empreendedor em função do ano de início do processo (solicitação da LP).

Os dados apresentados apontam no sentido de que os tempos totais de tramitação dos processos de licenciamento ambiental analisados não estão 
relacionados ao número de solicitações de informações complementares feitas pelos órgãos ambientais ao empreendedor no decorrer do processo, nem ao número de impactos ambientais identificados no EIA nem, tampouco, ao número de condicionantes constantes na LP expedida.

Neste sentido, fatores não quantificáveis, como deficiências no estudo ambiental, principalmente relacionadas à precariedade ou mesmo ausência de estudos de alternativas locacionais (uma grave deficiência nos EIAs consultados) e a proposição de implantação do empreendimento em locais inadequados, dadas as restrições ambientais, aparentemente apresentam maior interferência sobre os tempos de tramitação. De fato, a leitura dos processos e EIAs permite concluir que a escolha de alternativa locacional inadequada do ponto de vista ambiental acaba por resultar em uma grande interferência da sociedade civil organizada e do Ministério Público durante o processo de licenciamento em questão.

A conclusão de que o tempo de tramitação dos processos depende do grau de interferência de agentes como o Ministério Público e a sociedade civil organizada destacando-se que a participação pública no processo decisório é um dos princípios básicos da AIA, segundo IAIA (1999) - e que, ao menos nos casos observados, tal interferência é mais notória nas situações em que os empreendimentos são propostos em locais que apresentam maiores restrições ambientais, reforça a necessidade da escolha de alternativas locacionais ser considerada com mais seriedade pelos empreendedores e órgãos ambientais envolvidos ao licenciamento.

Neste sentido, os trabalhos de Kirchhoff et al. (2007), Ranieri et al. (2005) e Souza et al. (2007) apontam a necessidade de, previamente ao licenciamento, serem elaborados estudos específicos voltados à apresentação de alternativas locacionais que considerem critérios ambientais e critérios econômicos com o mesmo nível de importância para a tomada de decisão (IAIA, 2002), ponto central na busca da sustentabilidade ambiental (GLASSON et al 2005, WOOD, 1995, HARVEY, 1998) . Tais estudos, servindo como base de referência para a escolha da melhor localização para instalação de empreendimentos, devem ser feitos de forma participativa, envolvendo empreendedor, órgãos ambientais e a sociedade civil, a fim de minimizar os conflitos posteriores e tornar mais eficientes os procedimentos de licenciamento ambiental, uma vez que tendem a reduzir o tempo total de tramitação dos processos de licenciamento. 


\section{CONCLUSÕES}

As análises feitas dos processos de licenciamento ambiental demonstram que o número de solicitações de informações complementares feitas pelos órgãos ambientais ao empreendedor no decorrer do processo, o número de impactos ambientais identificados no EIA e o número de condicionantes constantes na LP expedida não estão relacionados ao tempo total de tramitação dos processos.

Os processos que apresentaram maior tempo de tramitação sob responsabilidade do empreendedor, e conseqüentemente maior tempo de tramitação total do processo, foram aqueles cujos empreendimentos foram propostos em alternativas locacionais mais restritivas do ponto de vista ambiental.

A análise de alternativas locacionais nos EIAs, condição obrigatória conforme a norma brasileira, é tratada de forma precária e tem sua importância subestimada pelos empreendedores, se constituindo numa das principais deficiências observadas nos EIAs apresentados.

Os critérios econômicos (como proximidade com pólos consumidores, disponibilidade de insumos, infra-estrutura de transporte, acessibilidade ao local, disponibilidade e custos das propriedades afetadas pelo empreendimento, entre outros) prevalecem na escolha das alternativas locacionais dos empreendimentos em detrimento de critérios ambientais (capacidade de suporte do meio para receber o empreendimento proposto). Neste sentido, os EIAs têm se reduzido a documentos destinados à identificação dos impactos e determinação das medidas mitigadoras de decisões econômicas e políticas já estabelecidas previamente ao licenciamento.

Os resultados reforçam a necessidade de estudos específicos voltados à apresentação de alternativas locacionais a serem elaborados previamente ao licenciamento e que sirvam como base de referência para a escolha da melhor localização para o empreendimento, considerando critérios ambientais e critérios econômicos com o mesmo nível de importância para a tomada de decisão a fim de minimizar os conflitos posteriores e tornar mais eficientes os procedimentos de licenciamento ambiental.

Tais estudos serviriam também como base de referência para subsidiar a análise de viabilidade ambiental de planos, programas e políticas em cenário nacional, 
e em especial ao setor energético brasileiro, desde a elaboração de estudos de projeção da matriz energética nacional, considerando critérios ambientais na formulação dos diversos cenários, até a tomada de decisão sobre a implementação das políticas públicas, como no caso do Plano Prioritário de Termeletricidade (PPT). Tal análise de viabilidade ambiental de planos, programas e políticas trata-se do objetivo principal da Avaliação Ambiental Estratégica, instrumento de planejamento ambiental instituído pela PNMA por meio da AIA, mas que necessita, atualmente, de regulamentação e normatização de procedimentos. 


\section{RECOMENDAÇÕES}

É importante mencionar que fatores político-institucionais, que não foram considerados neste trabalho e merecem estudos específicos, podem ter influência na agilidade dos órgãos responsáveis na análise da viabilidade ambiental dos empreendimentos. Exemplos de fatores político-institucionais que podem interferir nos tempos de tramitação de processos de licenciamento ambiental são:

- normas que estabelecem prazos de análise por parte dos órgãos ambientais (que priorizam a quantidade de licenças emitidas e não necessariamente a qualidade das análises);

- existência de procedimentos burocráticos na tramitação dos processos;

- disponibilidade de recursos e infra-estrutura aos órgãos ambientais;

- comunicação deficiente entre os diversos agentes envolvidos no processo;

- número e capacitação de funcionários dos órgãos ambientais envolvidos com o licenciamento;

- número de processos em tramitação ao mesmo tempo nos órgãos ambientais, entre outros.

Também não se pode descartar a possibilidade de interferência nos tempos de tramitação ocorrer devido a privilégio para a análise de determinados empreendimentos em detrimento de outros em função de interesses políticos, econômicos e institucionais.

Estudos que ampliem o recorte dado nesta pesquisa e analisem processos de licenciamento ambiental de outras tipologias de empreendimentos e que tenham tramitado no âmbito de outras agências, nacionais ou internacionais, seriam de suma importância, uma vez possibilitaria a identificação de outros fatores inerentes aos procedimentos específicos adotados com potencial de interferirem no tempo de tramitação dos processos.

Entende-se que, não somente diante dos resultados desta pesquisa como também de tantos estudos relacionados ao assunto, há a necessidade da implementação de um estudo específico, em momento prévio ao licenciamento ambiental, que sirva como base de referência para estudos de alternativas locacionais, no sentido de incorporar critérios ambientais desde a fase de planejamento até a tomada de decisão de ações estratégicas de desenvolvimento dos diversos setores. 
Há necessidade do desenvolvimento, no âmbito das agências ambientais, de competências para boas práticas da AIA, no sentido de aperfeiçoamento constante dos procedimentos, revisão periódica de legislação ambiental pertinente, capacitação e treinamento do corpo técnico envolvido na análise, parcerias, trocas de informações e conhecimentos entre as instituições. Tais atividades devem acompanhar as tendências de crescimento econômico e o dinamismo das alterações estabelecidas por procedimentos e instrumentos regulamentares (legislações municipais, planos de comitês de bacias hidrográficas, planos diretores municipais, entre outros). 


\section{REFERÊNCIAS BIBLIOGRÁFICAS}

ANEEL - Agência Nacional de Energia Elétrica (2005). Atlas de Energia Elétrica do Brasil. $2^{\mathrm{a}}$ edição. Brasília, DF.

AGUILAR, G.D. (2006). Licenciamento Ambiental para Implantação de PCHs no Brasil. Editorial Revista PCHnotícias \& SHPnews, Ano 8, Edição 28, Jan/Fev/2006.

ASSOCIAÇÃO DOS SERVIDORES DO IBAMA-DF (2004). A verdade sobre o licenciamento ambiental federal. [documento divulgado via correio eletrônico]. Mensagem recebida por <victor.ranieri@mma.gov.br>.

BRASIL (1981). Lei Federal no 6.938 de 31 de agosto de 1981. Dispõe sobre a Política Nacional do Meio Ambiente, seus fins e mecanismos de formulação e aplicação, e dá outras providências. Brasília, DF.

BRASIL (1986). Resolução do Conselho Nacional do Meio Ambiente (CONAMA) no 001 de 23 de janeiro de 1986. Dispõe sobre as definições, as responsabilidades, os critérios básicos e as diretrizes gerais para uso e implementação da Avaliação de Impacto Ambiental. Brasília, DF.

BRASIL (1997a). Lei Federal no 9.478 de 06 de Agosto de 1997. Dispõe sobre a política energética nacional, as atividades relativas ao monopólio do petróleo, institui o Conselho Nacional de Política Energética e a Agência Nacional do Petróleo e dá outras providências. Diário Oficial da República Federativa do Brasil, Brasília, DF.

BRASIL (1997b). Resolução do Conselho Nacional do Meio Ambiente (CONAMA) no 237 de 19 de dezembro de 1997. Regulamenta os aspectos de licenciamento ambiental estabelecido na Política Nacional do Meio Ambiente. Diário Oficial da República Federativa do Brasil. Brasília, DF.

BRASIL (2001). Resolução do Conselho Nacional do Meio Ambiente (CONAMA) $n^{\circ}$ 279 de 27 de junho de 2001. Estabelece procedimentos para o licenciamento ambiental simplificado de empreendimentos elétricos com pequeno potencial de impacto ambiental. Diário Oficial da República Federativa do Brasil. Brasília, DF.

BRASIL (2000a). Decreto $n^{\circ}$ 3.371, de 24 de fevereiro de 2000. Institui, no âmbito do Ministério de Minas e Energia, o Programa Prioritário de Termeletricidade, e dá outras providências. Diário Oficial da República Federativa do Brasil, Brasília, DF. 
BRASIL (2000b). Lei Federal no 9.985 de 18 de julho de 2000. Regulamenta o art. 225, $\S 1^{\circ}$, incisos I, II, III e VII da Constituição Federal, institui o Sistema Nacional de Unidades de Conservação da Natureza e dá outras providências. Diário Oficial da República Federativa do Brasil, Brasília, DF.

CARVALHO, J. (2003). EDP desiste da térmica de Araraquara. Jornal Gazeta Mercantil, Hemeroteca do Instituto de Eletrotécnica e Energia, Caderno A8, no: 71448 de 09 mai. 2003.

CCEM - Escola de Comando e Estado Maior da Aeronáutica (2008). Disciplina: Pesquisa Científica. Texto 8 - A Pesquisa e o Método Científico. $<$ http://www.unifa.aer.mil.br/ecemar/pesquisa/Textos2005_8.htm>. Acesso em: 01 mar. 2008.

CNI - Confederação Nacional da Indústria (2007a). Empresas enfrentam dificuldades no Licenciamento Ambiental. Sondagem Especial da Confederação Nacional da Indústria, Ano 5, Número 2.

CNI - Confederação Nacional da Indústria (2007b). Mais agilidade e eficácia para o licenciamento. Revista Eletrônica - Licenciamento Ambiental. Jul, 2007b. Disponível em:

<http://implantacao.cni.org.br/portal/data/pages/8A9015D218CCD44B0118CCEFA24B 2861.htm>. Acesso em: 26 mar. 2008.

COLLET, L. (2005). Pedra no sapato do setor elétrico. JB On Line. Rio de Janeiro, 30 mar. 2005. Caderno Economia. Disponível em:

<http://quest1.jb.com.br/jb/papel/economia/2005/03/30/joreco20050330010.html>. Acesso em: 28 jan. 2008.

CUOCO, E. (2001). Liminar barra construção de termelétrica em Cubatão. Folha on Line. 20 abr. 2001. Disponível em:

<http://www1.folha.uol.com.br/folha/dinheiro/ult91u19821.shtml>. Acesso em: 18 mai. 2008.

EBC - Empresa Brasileira de Comunicação (2008). Reserva de gás descoberta em Santos pode levar à auto-suficiência, estima Petrobrás. 28 jan. 2008. Disponível em: $<$ http://www.agenciabrasil.gov.br/noticias/2008/01/22/materia.2008-0122.0361012402/view>. Acesso em: 03 fev. 2008. 
FORTUNATO NETO, J. (2004). Análise do relatório ambiental preliminar (RAP) como instrumento de avaliação e de suporte para o licenciamento ambiental. Dissertação (Mestrado) - Escola de Engenharia de São Carlos. Universidade de São Paulo, São Carlos.

GLASSON, J.; SALVADOR, N.N.B. (2000). EIA in Brazil: a procedures-practice gap. A comparative study with reference to the European Union, and especially the UK. Environmental Impact Assessment Review, Amsterdam, v.20, n.2, p.191-225.

GLASSON, J.; THERIVEL, R.; CHADWICK, A. (2005). Introduction to environmental impact assessment. 3rd. Edition. London.

GODOY, A.S. (1995). Introdução à pesquisa qualitativa e suas possibilidades. In: Revista de Administração de Empresas. v.35. n.2. São Paulo: RAE.

GOMIDE, F. (2004). Meio Ambiente-BRASIL: Avanços e obstáculos pós-Rio-92. Pergunta para debate: Como atender às necessidades energéticas do País de forma sustentável? Respostas dos representantes dos diversos setores, $2^{\mathrm{a}}$ edição revista, Ministério de Minas e Energia. Brasília, DF.

GUADAGNINI, M.A. (2006). Fontes Alternativas de Energia - Uma visão geral. Trabalho de Conclusão de Curso. Pós-Graduação Executiva em Meio Ambiente. Universidade Federal do Rio de Janeiro - COPPE/UFRJ. Rio de Janeiro.

HARVEY, N. (1998). Environmental Impact Assessment - procedures, practices and prospects in Australia. Oxford: Oxford University Press.

HORTA NOGUEIRA, L.A. (2001). Produção e processamento de petróleo e gás natural no Brasil: perspectivas e sustentabilidade nos próximos 20 anos. Agência Nacional do Petróleo. Brasília, DF.

IAIA - INTERNATIONAL ASSOCIATION FOR IMPACTO ASSESSMENT (1999). Principles of Environmental Impact Assessment Best Practice. January.

IAIA - INTERNATIONAL ASSOCIATION FOR IMPACTO ASSESSMENT (2002). The Linkages between impact assessment and the sustainable development agenda, and recommendations for actions. Fargo.

KIRCHHOFF, D. ; MONTAÑO, M. ; RANIERI, V.E.L. ; OLIVEIRA, I.S.D.; DOBERSTEIN, B.; SOUZA, M.P. (2007). Limitations and drawbacks of using 
Preliminary Environmental Reports (PERs) as an input to Environmental Licensing in São Paulo State: A case study on natural gas pipeline routing. Environmental Impact Assessment Review, v.27, p.301-318.

LAKATOS, E.M.; MARCONI, M. de A. (1987). Metodologia do Trabalho Científico. São Paulo: Atlas, 198p.

LOURENÇO, S.R. (2003). Gás Natural: perspectivas e utilização. Dissertação (Mestrado). Programa de Pós Graduação em Planejamento de Sistemas Energéticos, Universidade Estadual de Campinas. Campinas.

MENDES, D.; FEITOSA, A. (2008). IBAMA reduzirá em mais de 50\% prazo para concessão de licença ambiental. Brasília - DF. 17 jul. 2007. Disponível em: <http://www.mma.gov.br/ascom/ultimas/index.cfm?id=4241>. Acesso em: 13 set. 2008.

MME - Ministério de Minas e Energia (2006a). Matriz Energética Nacional: Projeção da Matriz Energética Nacional 2005 - 2023. Conselho Nacional de Política Energética CNPE. Brasília, DF.

MME - Ministério de Minas e Energia (2006b). Plano Decenal de Expansão de Energia 2006/2015, Secretaria de Planejamento e Desenvolvimento Energético, Brasília, DF.

MME - Ministério de Minas e Energia (2007). Balanço Energético Nacional - 2007. Brasília - DF. Disponível em:

<http://www.mme.gov.br/site/menu/select_main_menu_item.do?channelld=1432\&page Id=10780 >. Acesso em: 28 abr. 2007.

MPF - Ministério Público Federal (2004). Deficiências em Estudos de Impacto Ambiental: síntese de uma experiência. Brasília: $4^{\mathrm{a}}$ Câmara de Coordenação e Revisão, Escola Superior do Ministério Público da União.

MONOSOWSKI, E. (1990). Lessons from the Tucuruí experience. Water Power and Dam Construction. February.

MOREIRA, I.V.D. (1988). Environmental Impact Assessment: theory and practice. London: Unwin Hyman.

O ESTADO DE SÃO PAULO (2007). Ambiente é desculpa para a incapacidade Entrevista de Ricardo Brandt com Mário Mantovani. São Paulo, 11 mai. 2007. 
Disponível em: <http://www.jornaldaciencia.org.br/Detalhe.jsp?id=46823>. Acesso em: 28 jan. 2008.

PINHEIRO-PEDRO, A.F. (2006). O licenciamento ambiental e sua sustentabilidade no Brasil. Revista Ambiente Legal, São Paulo, n.3, abr/mai/jun, 2006. Disponível em: <http://www.revistaambientelegal.com.br/edicao03/francamente.htm>. Acesso em: 28 jan. 2008.

RANIERI, V.E.L.; MONTAÑO, M.; FONTES, A.T.; OLIVEIRA, I.S.D.; SOUZA, M.P. (2005). O zoneamento ambiental como instrumento de política e gestão ambiental. In: ESPÍNDOLA, E. L.G.; WENDLAND, E. (Org.). PPG-SEA: Trajetórias e perspectivas de um curso multidisciplinar. São Carlos: Rima Editora, v. 4, p.109-136.

RANIERI, V.E.L. (2008). Material da disciplina de Avaliação de Viabilidade Ambiental. Curso de Graduação em Engenharia Ambiental. Universidade de São Paulo - Escola de Engenharia Ambiental. São Carlos.

ROMERO, J.F.L. (2002). Licenciamento ambiental das usinas termoelétricas no estado de São Paulo. In: I Encontro Associação Nacional de Pós Graduação e Pesquisa em Ambiente e Sociedade (ANPPAS). Pós Graduação em Energia - Instituto de Eletrotécnica e Energia. Universidade de São Paulo.

SÁNCHEZ, L.E. (2006). Avaliação de Impacto Ambiental: conceitos e métodos. São Paulo: Editora Oficina de Textos, 495 p.

SÃO PAULO (1989). Constituição do Estado de São Paulo de 5 de outubro de 1989. Cap. IV - Do Meio Ambiente, dos Recursos Naturais e do Saneamento, Art. 192.

SÃo PAULO (1994). Resolução SMA 42 de 29 de dezembro de 1994. Dispõe sobre procedimentos para análise de Estudos de Impacto Ambiental (EIA e RIMA) no âmbito da Secretaria do Meio Ambiente.

SÃO PAULO (2004). Resolução SMA 54 de 30 de novembro de 2004. Dispõe sobre procedimentos para o licenciamento ambiental no âmbito da Secretaria do Meio Ambiente.

SMA - Secretaria do Meio Ambiente do estado de São Paulo (1998). Processo SMA 13.698/1998. Licenciamento Ambiental da Usina Termelétrica Central de Cogeração da Baixada Santista. 
SMA - Secretaria do Meio Ambiente do estado de São Paulo (1999). Processo SMA 13.696/1999. Licenciamento Ambiental da Usina Termelétrica Santa Branca.

SMA - Secretaria do Meio Ambiente do estado de São Paulo (2000a). Processo SMA 13.629/2000. Licenciamento Ambiental da Usina Termelétrica Duke Energy 1.

SMA - Secretaria do Meio Ambiente do estado de São Paulo (2000b). Processo SMA 13.545/2000. Licenciamento Ambiental da Usina Termelétrica Carioba II.

SMA - Secretaria do Meio Ambiente do estado de São Paulo (2001). Processo SMA 13.506/2001. Licenciamento Ambiental da Usina Termelétrica Araraquara.

SMA - Secretaria do Meio Ambiente do estado de São Paulo (2003). Processo SMA 13.734/2003. Licenciamento Ambiental da Usina Termelétrica Araraquara.

SOUZA, M.P (2000). Instrumentos de Gestão Ambiental: Fundamentos e Prática. São Carlos: Riani Costa.

SOUZA, M.P.; OLIVEIRA, I.S.D.; FONTES, A.T.; MONTAÑO, M.; RANIERI, V.E.L. (2007). A base de referência e os instrumentos de política ambiental. In: 24.0 Congresso Brasileiro de Engenharia Sanitária e Ambiental. Belo Horizonte. Anais. Rio de Janeiro: Associação Brasileira de Engenharia Sanitária e Ambiental - ABES, CDROM.

VERGARA, S.C. (2007). Projetos e Relatórios de Pesquisa em Administração. $8^{a}$ ed. São Paulo: Atlas.

WILLIAMS, R.H. (2000). Advanced Energy Supply Technologies. In World Energy Assessment: Energy and the Challenge of Sustainability. New York, NY: United Nations Development Program.

WOOD, C. (1995). Environmental Impact Assessment. Prentice Hall. 
ANEXOS

Anexo 1. Resolução SMA 42 de 29/12/1994 
Anexo 2. Resolução SMA 54 de 30/11/2004 
Anexo 3. Medida Provisória nº 2.147 de 15/05/2001 